
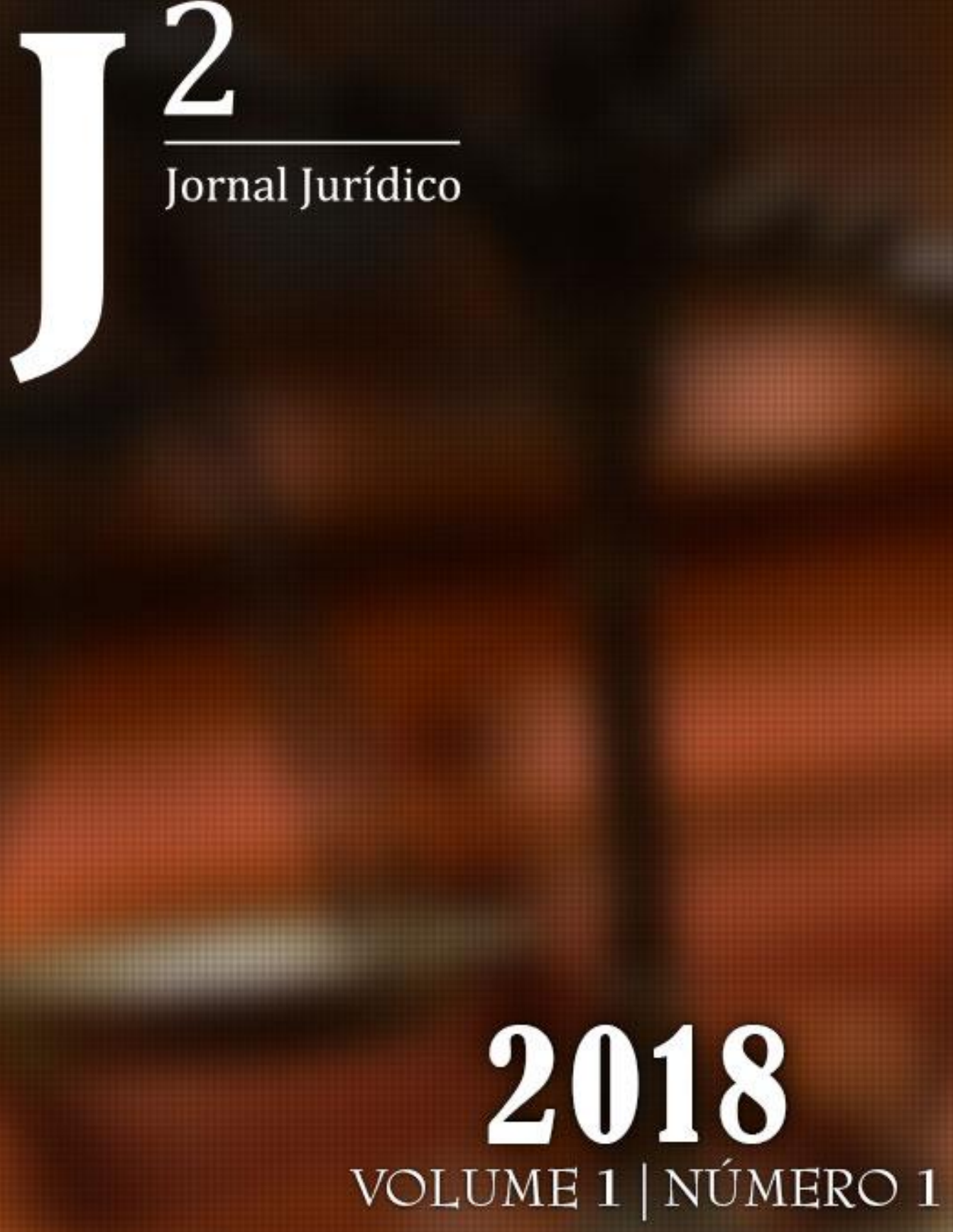

ISSN (ONLINE): 2184-3082 | SEMESTRAL

pontěditora 


\section{Editor-chefe}

Doutora Cristiane Sousa Reis - Universidade Federal Fluminense

\section{Conselho Científico}

Allen Silva - Assessor do Tribunal de Justiça do Estado do Rio de Janeiro | Investigador na Universidade Candido Mendes | Membro da Associação Brasileira de Relações Institucionais e Governamentais (ABRIG)|Membro do Fórum Nacional de Gestores de Inovação e Transferência de Tecnologia (FORTEC) | Membro na AB2L - Associação Brasileira de Lawtechs e Legaltechs |Bolsista na Universidade do Estado do Rio de Janeiro

Ana Rita Babo Pinto - Técnica Superior Jurista | Banco de Portugal

Ana Roso - Coimbra Business School | ISCAC |

António Monteiro Delgado - Universidade de Lisboa | Docente na Universidade de Cabo Verde e Universidade do Mindelo

Bartolomeu Varela - Docente e investigador na Universidade de Cabo Verde |Advogado e Consultor Jurídico

Carolina Braga - Residente Jurídico na Procuradoria Geral do Município do Rio de Janeiro | Advogada, KCB Advogados

Carolina Merida - Professora na Universidade de Rio Verde - FESURV | Procuradora na Prefeitura Municipal de Rio Verde

Eduardo Alves - Investigador integrado no Centro de Investigação de Estudos Regionais e Locais (CIERL | Universidade da Madeira

Fabrizio Bon Vecchio - Sócio titular da banca de advogados "Vecchio Sociedade de Advocacia"

Ines Castelo Branco - Doutoranda na Faculdade de Direito da Universidade de Coimbra| Advogada na CRBA - Sociedade de Advogados, RL

Joaquim Ramalho - Docente na Universidade Fernando Pessoa

João Proença Xavier - Universidade de Salamanca (Espanha)

Marina Gadelha - PhD em Direito | Universidade Católica de Pernambuco

Mônica Gusmão - Docente de Direito Empresarial, Universidade Cândido Mendes

Obede Dias - Advogada Criminalista de Segurança Pública, Social e Civil | Faculdade de Jundiaí Unianchieta, Brasil

Otávio França - Membro do Instituto Brasileiro de Direito Desportivo|Advogado integrante da Ordem dos Advogados do Brasil

$\mathbf{J}^{2}$ - Jornal Jurídico | Volume 1 | Número 1 
Rui Ferreira - Advogado, António Vilar, Luís Cameirão \& Associados | Juíz-Árbitro, Centro de Arbitragem Administrativa | Professor Adjunto Convidado, Escola Superior de Tecnologia e Gestão do Instituto Politécnico de Leiria $\mid$ Assistente Convidado, Instituto Politécnico de Bragança.

Sancha Campanella - Instituto Superior de Administração e Línguas da Madeira|ISAL 


\section{Ficha Técnica}

Periodicidade: Semestral (janeiro, julho)

Propriedade/Editora: Ponte Editora, Sociedade Unipessoal, Lda.

\section{Contactos}

Telefone: 291723010

E-mail: geral@ponteditora.org

\section{Endereço para correspondência:}

$\mathbf{J}^{2}$ - Jornal Jurídico.

Startup Madeira - Sala 3

Campus da Penteada

9020-105 Funchal, Madeira 


\section{Estatuto Editorial}

$\mathbf{I}$ - O $\mathbf{J}^{\mathbf{2}}$ - Jornal Jurídico, conhecido também pela forma abreviada de $\mathbf{J}^{\mathbf{2}}$, é uma publicação periódica. Propriedade da Editora: Ponteditora.

II - O $\mathbf{J}^{\mathbf{2}}$ pretende divulgar trabalhos e estudos científicos da área do Direito, através de pesquisas interdisciplinares e correlacionadas com o campo jurídico.

III - A linha editorial do $\mathbf{J}^{\mathbf{2}}$ centra-se na área do Direito, abrangendo várias áreas do conhecimento metodológico crítico e progressista.

IV - O $\mathbf{J}^{\mathbf{2}}$ tem por missão poder contribuir para o desenvolvimento da investigação Jurídica e de Direito em Portugal, na CPLP e na Diáspora de língua portuguesa pelo mundo.

$\mathbf{V}-\mathrm{O}^{\mathbf{2}}$ é editado semestralmente, em papel, em Portugal e, quando se justificar, na CPLP, sendo disseminada no resto do mundo através da Internet.

VI - O J $\mathbf{J}^{2}$ terá, aproximadamente, 80 a 100 páginas de formato A4 e uma tiragem em papel inferior a 1000 exemplares.

VII - O J $\mathbf{J}^{2}$ destina-se a professores, investigadores e académicos, nacionais ou estrangeiros.

VIII - O $\mathbf{J}^{\mathbf{2}}$ apresenta um corpo editorial técnico e científico, aberto a académicos, investigadores e profissionais oriundos de diversas organizações e empresas relacionadas com a investigação jurídica e de Direito.

$\mathbf{I X}-\mathrm{O} \mathbf{J}^{2}$ publica artigos académicos e científicos, originais e de revisão.

$\mathbf{X}-\mathrm{O} \mathbf{J}^{\mathbf{2}}$ publica em português, podendo excecionalmente apresentar artigos noutra língua, desde que se trate de uma língua reconhecida internacionalmente no meio académico e profissional, como por exemplo em inglês.

$\mathbf{X I}-\mathrm{O} \mathrm{J}^{2}$ pretende promover o intercâmbio de ideias, experiências e projetos entre os autores e editores, contribuindo para a reflexão do Direito e para a sua ligação com a sociedade. 


\section{Índice}

\section{Editorial}

Editorial

O capital simbólico das decisões judiciais em versos e o acesso à Justiça.

The symbolic capital of judicial decisions in verses and the access to Justice.

9

O (in)efetivo acesso à justiça no emprego público

The (in)effective access to justice in public employment law

Formula aequalitas na actividade administrativa

Formula aequalitas in administrative activity

Fundo de Garantia Salarial - O prazo para requerer o pagamento dos créditos laborais e a sua (in)compatibilidade com o Direito Comunitário e a Constituição

Salary Guarantee Fund - The time-limit for lodging applications for payment of outstanding salary and its (in)compatibility with the Community Law and the Constitution

$\mathbf{J}^{2}$ - Jornal Jurídico | Volume 1 | Número 1 


\section{pontěditora}

\section{Editorial}

Editorial

Diretora da $\mathrm{J}^{2}$, Cristiane Sousa Reis ${ }^{1}$

${ }^{1}$ E-mail: csouzareis@gmail.com

Universidade Federal Fluminense

O Jornal Jurídico $\left(\mathrm{J}^{2}\right)$ é uma publicação académica semestral, que tem por foco e escopo a divulgação de trabalhos científicos da área do Direito e sua transversalidade, sob um olhar crítico, privilegiando pesquisas interdisciplinares e correlacionadas com o campo jurídico, com o objetivo de divulgar a língua portuguesa na CPLP.

Imerso neste espírito, a primeira edição do Jornal Jurídico $\mathrm{J}^{2}$ é composta por três artigos científicos selecionados conforme as regras definidas no processo de avaliação por pares, seguindo uma avaliação preliminar (desk review) e posterior avaliação cega por pares, conhecida por (double blind review), realizada por dois consultores ad hoc.

O primeiro artigo intitulado $O$ capital simbólico das decisões judiciais em versos e o acesso à Justiça, dedica-se à reflexão dos discursos contidos nas decisões judiciais, sobretudo em razão das palavras rebuscadas utilizadas, analisando, em contraponto à rigidez da estrutura formal das decisões judiciais, analisou-se alguns pronunciamentos judiciais proferidos em versos, buscando saber até que ponto esses atos judiciais assim enunciados retiram a dimensão de poder sobre os usuários do Poder Judiciário, diminuindo seu capital simbólico. Interessou também avaliar em qual medida esses atos aproximam os utentes do Poder Judiciário, facilitando o acesso ao Direito.

O segundo artigo, intitulado Fundo de Garantia Social - O prazo para requerer o pagamento dos créditos laborais e a sua (in)compatibilidade com o Direito Comunitário e a Constituição traz uma importante questão aos leitores que é a análise do prazo do trabalhador para requerer o Fundo de Garantia Social, que garante o pagamento dos créditos emergentes de contrato de trabalho, de sua violação ou de sua cessação, que não possam ser pagos pelo empregador por motivo de insolvência ou dificuldade financeira, apresentando, ao final do texto, uma sugestão à problemática levantada.

Já o terceiro artigo intitula-se $O$ (in)efetivo acesso à justiça no emprego público traz-nos uma relevante discussão sobre o direito de acesso ao direito e á tutela jurisdicional efetiva na esfera do emprego público, questionando a própria competência do tribunal. Serão os tribunais administrativos e fiscais os mais competentes para conhecer de litígios na área suscitada? 
Haveria maior efetividade no âmbito dos juízos do trabalho? São estas as perguntas que a autora vem responder, com grande relevância ao aprofundamento dos direitos fundamentais.

Tendo-se apresentado os artigos que constam desta primeira edição, convida-se os leitores à uma leitura criteriosa, crítica dos trabalhos aqui apresentados e que contribuem ainda mais com a produção académica dos temas propostos e instigantes, deixando, desde já, o convite a futuras participações, para promovermos ainda mais o debate e enriquecermos o campo jurídico sob uma pesrpectiva crítica, inovadora.

Cristiane Reis 


\title{
O capital simbólico das decisões judiciais em versos e o acesso à Justiça.
}

\author{
The symbolic capital of judicial decisions in verses and the access to Justice.
}

Cristiane de Souza Reis ${ }^{1}$; ${ }^{1}$ E-mail: csouzareis@gmail.com Universidade Federal Fluminense
Resumo: O presente artigo analisa o capital simbólico presente nas decisões judiciais proferidas em versos e o acesso à Justiça. Não obstante as mesmas apresentem-se de uma forma menos densa, conferindo suavidade na leitura, ainda assim mantém palavras rebuscadas e termos técnicos sem explicação e, portanto, sem acessibilidade e inteligibilidade aos destinatários finais das decisões (povo), conservando o capital simbólico próprio do Poder Judiciário, que mantém a dimensão de poder sobre os súditos do Estado. Conclui-se, portanto, que as decisões judicias, ainda que em versos, são destinadas aos iniciados da ciência jurídica e não promovem o acesso à Justiça. Para a pesquisa, foram analisadas sete decisões judiciais proferidas em versos, bem como elaborado um questionário, tendo sido os dados analisados sob a luz da Análise Crítica do Discurso.

Palavras-chave: Decisões judiciais em versos. Acesso à Justiça. Direitos Humanos. Controle social.

Abstract: This article analyzes the symbolic capital present in the judicial decisions handed down in verses and the access to Justice. Nevertheless they present themselves in a less dense form, conferring softness in the reading, but it also maintains elaborate words and technical terms without explanation and, therefore, without accessibility and intelligibility to the final recipients of the decisions (people), conserving the own symbolic capital, which maintains the dimension of power over the subjects of the State. It is concluded, therefore, that the judicial decisions, although in verses, are destined to the initiates of the legal science and does not promote the access to Justice. For the research, seven judicial decisions were analyzed in verses, as well as a survey was elaborated, being the data analyzed in the light of the Critical Discourse Analysis.

Keywords: Judicial decisions in verses. Acess to Justice. Human Rights. Social Control. 


\section{Introdução}

Os pronunciamentos dos juízes brasileiros nos processos judiciais dão-se por meio de quatro atos: sentenças, decisões interlocutórias e despachos. As sentenças são atos processuais exclusivos dos juízes e é por meio delas que o processo judicial se encerra. As sentenças são proferidas por juízes de primeira instância (órgão singular), enquanto os acórdãos, que possuem a mesma natureza, são proclamados pelos tribunais (órgão colegiado e, via de regra, instância onde ocorre o processamento e o julgamento dos recursos interpostos). As decisões interlocutórias são pronunciamentos judiciais que tem o condão de decidir alguma situação sobre a lide processual, mas não põe fim à mesma. Os despachos correspondem a todos os demais atos do juiz, praticados de ofício, isto é, por iniciativa do magistrado, ou a requerimento da parte. Os atos processuais, e neles estão incluídos os judiciais acima mencionados, seguem alguns requisitos gerais e outros específicos previstos no Código de Processo Civil ou Penal, conforme o caso.

No presente artigo, pretende-se refletir sobre a estrutura dos discursos inseridos nos pronunciamentos judiciais, não no seu aspecto jurídico-processual, mas antes na dimensão de poder contida na rigidez de sua construção, sobretudo pelo uso de terminologia rebuscada, seu capital simbólico, muitas das vezes inatingíveis pelos usuários que se socorrem do Poder Judiciário, produzindo afastamento da população em geral e consequente obstáculo ao acesso ao Direito. No entanto, não se analisará quaisquer decisões, mas sim aquelas que, contrapondo a rigidez da estrutura arquétipa dos pronunciamentos judiciais, são proferidas em versos por alguns juízes, rompendo com o rigor esperado pela comunidade jurídica e até mesmo pela sociedade em geral. É sobre elas que o meu olhar recairá neste artigo. Até que ponto esses pronunciamentos em versos retiram a dimensão de poder sobre os usuários do Poder Judiciário diminuindo seu capital simbólico? Os pronunciamentos judiciais em versos rompem efetivamente com o rigor do modo de dizer próprio do campo jurídico? Em qual medida os atos judiciais em versos aproximam os utentes do Poder Judiciário, facilitando o acesso ao Direito? Para compreender estas questões, foram analisados sete atos judiciais proferidos em versos, sendo importante registrar desde já que estes atos foram assim apresentados de modo isolado, não constituindo a prática comum de escrita e forma de redação do ato judicial do agente judicial analisado. Foi elaborado um questionário em plataforma digital (Google), respondido 
por 65 pessoas $^{1}$, com o objetivo de avaliar a percepção das pessoas acerca da estrutura das decisões em versos, aceitação e a inteligibilidade das mesmas em termos de facilitação ou não do acesso à Justiça. Utilizou-se como referencial metodológico a Análise Crítica do Discurso (ACD), de Norman Fairclough (2001), que compreende o papel da linguagem na conformação das relações sociais de poder, sendo o discurso analisado sob um modelo tridimensional: análise textual, prática discursiva e prática social. Segundo Wodak (2003, p. 17-34), a “ACD permite analisar as pressões provenientes de cima e as possibilidades de resistência às relações desiguais de poder que aparecem em forma de convenções sociais". A ACD analisa como as "ideias e objetos produzidos socialmente constroem determinada realidade social" (Rodrigues \& Dellagnelo, 2016). Neste sentido, o próprio Fairclough (2003, p. 185) afirma que

a ACD é uma forma de ciência crítica que foi concebida como ciência social destinada a identificar os problemas que as pessoas enfrentam em decorrência de formas particulares da vida social e destinada, igualmente, a desenvolver recursos de que as pessoas podem se valer a fim de abordar e superar esses problemas.

Para melhor compreensão da predominância da escrita no processo brasileiro, importante registrar que há dois sistemas reinantes no Ocidente. O Civil Law e o Common Law. Muito brevemente resumindo, o Civil Law possui raízes no direito romano e fundou suas estruturas na codificação, nas leis, adquirindo relevância os brocardos "vale o que está escrito", "ninguém pode dizer que desconhece a lei”, entre outros; já o Common Law, de origem anglo-saxônica, tem suas bases na jurisprudência. Neste sistema, a oralidade tem primazia, enquanto no primeiro, a predominância é a escrita. O Brasil segue o Civil Law ${ }^{2}$, o que denota a importância de refletirmos sobre a estrutura dos pronunciamentos judiciais enquanto prática social.

O Brasil, atualmente, enfrenta uma crise política movida e fomentada por algumas instituições da sociedade, como o Poder Judiciário e os meios de comunicação de massa, que, de forma cada vez mais nítida, vem ditar o movimento da sociedade em uma ou em outra direção. No entanto, não é desta política que irei tratar neste artigo, mas sim da estrutura de poder determinada pelo modo de dizer típico do campo jurídico, contraposto por algumas ousadas formas, que fogem, a princípio, ao rigor estrutural e fundante do habitus jurídico, como é o caso dos atos judiciais proferidos em versos.

\footnotetext{
${ }^{1} \mathrm{O}$ link do questionário foi divulgado na rede social Facebook.

2 Não se discutirá aqui se o Brasil vem ou não adentrado a um sistema misto.
} 


\section{Tipos de pronunciamentos judiciais e o rigor da sua estrutura enquanto dimensão de} poder

Na Antiguidade, a busca pela justiça significava a própria lei; posteriormente, com o advento do direito liberal e burguês, a lei ganhou proeminência e passou a ser a própria noção de justiça. Entender, após o surgimento do Estado, que o Direito é apenas aquele emanado por si, formatando-se em um bloco monolítico ${ }^{5}$ é conceber como justo apenas aquilo que a lei determina. Assim, o juiz passou a ser a voz e a mão pesada do Leviatã ${ }^{6}$. Da mesma forma que nos idos absolutistas, infringir a norma correspondia a lesar o soberano, não raras vezes resolvidas com punições supliciosas, como a sofrida pelo famoso e nunca esquecido Damiens (Foucault, 1999), nos tempos modernos e contemporâneos, violar a lei equivale a ofender o Estado (liberal) e a toda sociedade (ordeira), cabendo ao Poder Judiciário proferir rigorosas decisões, que começam pelo linguajar inatingível aos súditos mais comuns do Estado, terminando por sentenças que podem ou não refletir verdadeira Justiça. No entanto, não cabe neste artigo analisar as decisões judiciais no seu valor de justo (ou não), mas antes observar o distanciamento que a estrutura do dizer o Direito evidencia em relação à população que se socorre do Poder Judiciário, mantendo-se assim o seu poder.

Na tentativa de repor a ordem social, na concepção liberal de justiça, o Poder Judiciário vem aplicar a lei que foi elaborada e promulgada pelo legislador, como sendo aquele que sabe o que a sociedade quer e precisa. É como um dogma religioso. Aquele que viola a "santa mens legis" comete uma heresia e dentro deste arcabouço divino, a manutenção da imagem de Deus na terra só mudou da figura do soberano absolutista para o Estado, liberal. Deste modo, o representante de Deus na Terra, agora na forma de Estado, precisa manter essa mesma distância em relação aos seus súditos, aos seus fiéis. Assim, o Poder Judiciário, enquanto Estado-Juiz, apresenta-se com esta roupagem. Prestem atenção à arquitetura dos tribunais, de seu átrio, de seus gabinetes, de seus corredores. É acolhedora ou intimidatória? Imagine uma pessoa sem muitos recursos financeiros, sem muito conhecimento literário, adentrando nesse espaço para defender seus

\footnotetext{
${ }^{5}$ Apesar de o Poder Judiciário fazer se valer como única ente capaz de resolver conflitos, não conseguiu abafar as diversas outras formas de fazer Direito, naquilo que se convencionou chamar pluralismo jurídico.

${ }^{6}$ Thomas Hobbes publicou o livro Leviatã em 1651, tratando da estrutura da sociedade e do governo. Segundo Hobbes, os seres humanos são egoístas por natureza e, para não entrarem em contante guerra, uns contra os outros, faz-se necessário o contrato social, devendo o soberano (Leviatã) punir aqueles que violarem este contrato.
} 
direitos ou se defender de acusações (justas ou não). Como poderá se sentir esta pessoa? Imagine. Agora visualize esta mesma pessoa lendo a sentença de seu caso, com sua estrutura rígida, cumpridora dos seus requisitos mínimos essenciais sob pena de nulidade, na qual o léxico rebuscado consubstancia-se em poder e dominação sobre os demais. Sem sombra de dúvida, precisará de um intérprete, via de regra, o advogado que, quem sabe, poderá elucidar suas dúvidas (ou não, na medida em que vivencia esta mesma estrutura de poder _ assim como os demais operadores do Direito: membros do Ministério Público, da Defensoria Pública, dos cartórios judiciais, entre outros). Vemos, deste modo, que as instituições não se dissociam de seu processo discursivo, estando ambos interrelacionados (Maingueneau, 2008). Conforme dominantemente se compreende, da mesma forma que o legislador sabe quais leis são melhores à sociedade, o juiz, ser culto, conhece essas mesmas leis e quais devem ser aplicadas e para demonstrar seu poder e conhecimento, e faz uso de um conjunto lexical diferenciado do ser comum (Brito, 2016).

O próprio direito liberal, como se conhece, foi concebido para sustentar estruturas de poder dominantes, para manter a ordem e o status quo estabelecido. Importa mencionar que se está perante uma sociedade e um estado liberal e são esses princípios (antes liberais, hoje neoliberais) que o Direito pretende conservar. Em tempos passados, a figura do Juiz era exercida por qualquer cidadão. Quando passou a ter que arbitrar sobre interesses régios, já não era mais qualquer do povo e aquele que era incumbido da tarefa, deveria se profissionalizar. Já não mais é um "ser comum do povo". E para aqueles países que seguiram o modelo romano (civil law), a oralidade foi sendo gradativamente posta de lado, dando ensejo ao processo, na sua forma escrita. É histórico o distanciamento entre os agentes jurídicos e o povo.

Brito (2016) analisou algumas decisões judiciais, chamando atenção ao fato de o juiz colocarse sempre na primeira pessoa do singular, enquanto detentor do poder que lhe é imbuído pelo Estado e que ninguém ousa contestar, sempre também com expressões ritualísticas e imperativas, como "É o Relatório"; "Cite-se"; "Intime-se"; "Registre-se", concluindo que "o discurso autoritário do sujeito julgador 'barra' a voz do outro, ou seja, é um discurso monofônico, segundo Ducrot, pois as vozes que naturalmente se mostram nos textos polifônicos, são abafadas ou ocultadas sob a aparência de uma única voz nos discursos jurídicos, essencialmente monofônicos" (Brito, 2016). O Juiz representa este poder do Estado Leviatã, enquanto parte do mesmo, mas em nome da sociedade que teoricamente visa proteger e que, ao mesmo tempo, e paradoxalmente, por meio de seu rígido discurso acaba por provocar 
afastamento. Desta forma, enquanto provoca distanciamento, reafirma seu lugar de poder, correspondendo este a um modo de ação de uns sujeitos sobre outros, consubstanciados nas relações de força entre os sujeitos desiguais.

O Poder Judiciário, portanto, produz verdades jurídicas, porquanto emanadas de poder. Assim, é por meio do Direito que as relações de poder vigentes e dominantes criam discursos de verdade (Rocha, 2010). Neste sentido, percebe-se aquilo que Foucault (1984) chama de Microfísica do Poder. No aspecto político, o discurso jurídico possui a forma rígida e rebuscada, que provoca o afastamento dos jurisdicionados, para que mais facilmente as estruturas dominantes das relações sociais liberais que as fundam sejam mantidas. No plano interno, reafirma-se enquanto autoridade única capaz de ditar o direito, sedimentando-se a máxima de Francis Bacon de que "saber é poder". E mais, o discurso enquanto prática social remete o dizer à própria noção de fazer. Ditar o Direito assume-se como Fazer o Direito e o lugar que a escrita jurídica ocupa, com seu léxico rebuscado, com seus termos técnicos não esclarecidos (“juridiquês" não traduzido) remonta tempos idos e carregados de ideologia, na forma assinalada por Fairclough (2011, p. 119), que aduz que "as ideologias surgem nas sociedades caracterizadas por relações de dominação com base na classe, no gênero social, no grupo cultural", conformando e reafirmando seu capital simbólico e sua identidade social. De qualquer modo, a própria sociedade, por mais afastada que seja, espera dos operadores do Direito, aqui nos atendo aos magistrados, esta forma austera de dizer/fazer o Direito. Das 65 pessoas entrevistas, em relação à pergunta "se a decisão judicial for proferida em versos, como você reagiria em um primeiro momento?", 32 (49\%) achariam interessante, por ser diferente. 26 pessoas (40\%) entendem que o Judiciário não deve ser expressar em versos, já que é o órgão decisório da sociedade, devendo manter a sua forma de escrita. Sete pessoas (11\%) não se importam com a forma que as decisões são escritas. O modo de dizer próprio do Poder Judiciário possui um capital simbólico de poder (Bourdieu, 2005), assumindo o lugar do Leviatã (Estado-juiz), e que se materializa no poder real da manutenção do status quo social e aqui refiro-me à conservação das estruturas de poder dentro do Estado liberal, deixando de lado as questões muito claras para quem olha o Poder Judiciário sem as lentes da ocultação, observando todo o sistema de seletividade existente em seu seio. ${ }^{5}$

\footnotetext{
${ }^{5}$ Esta discussão foge ao objetivo do presente artigo, mas que vale a pena a reflexão em outros lugares mais oportunos.
} 


\section{O linguajar hermeticamente fechado e o acesso à Justiça}

Garantir acesso à Justiça é muito mais do que acesso ao socorro jurisdicional prestado pelo Poder Judiciário, um dos pilares do Estado Democrático de Direito, quando se compreende que o Estado avocou a tarefa de solução de $\operatorname{conflitos}^{6}$. É um direito fundamental de todos os cidadãos e promove a satisfação dos Direitos Humanos. Ter conhecimento dos direitos e garantias que estão disponíveis no ordenamento jurídico é também uma forma de acesso à Justiça. Dogmaticamente se compreende que o acesso ao Direito está assegurado quando as pessoas tem condições de se ampararem no Poder Judiciário para resolver suas demandas e nesta discussão entra a problemática dos elevados custos dos processos (incluindo taxas judiciárias, custas processuais e honorários advocatícios), questão que se resolve pelo apoio da Defensoria Pública, que garante assistência jurídica gratuita, bem como pelas formas de gratuidade de custas e taxas processuais. Discute-se ainda a morosidade judicial como um entrave ao pleno acesso à Justiça (com a descentralização das instâncias judiciárias como tentativa de solução). Sobre este aspecto, poder-se-ia mencionar ainda o excesso de recursos que podem ser interpostos para revisão de sentenças e que se aventa como mais um elemento causal da demora na prestação jurisdicional. Em alguns recintos dos tribunais, ainda se exige as vestes talares, que tem sua origem nas vestimentas sacerdotais da antiga Roma ${ }^{7}$. Veja mais uma vez a identificação divina que o Poder Judiciário representa.

Mas e o linguajar rebuscado, carregado de expressões latinas, e que, como já afirmado, afasta o usuário do Poder Judiciário de pleno entendimento das decisões que lhes dizem respeito, não seria também um obstáculo ao acesso à Justiça? No fundo, os operadores do direito (magistrados, promotores, defensores, advogados, serventuários do judiciário) não dialogam com o público em geral, com os utentes do serviço público. Segundo Chaim Perelman, a retórica e a argumentação jurídica visam persuadir e convencer o auditório universal. No entanto, compreende-se que este auditório não é aquele que busca a solução de sua lide. Falam para dentro, para seus iguais, para a circulação interna do poder, que não pode dali sair.

\footnotetext{
${ }^{6}$ Importante referenciar que a administração de conflitos não cabe só ao Estado. No entanto, esta questão não será aqui abordada.

${ }^{7}$ Estas vestimentas podem ser compreendidas como um capital simbólico representativo do poder por meio de comunicação não-verbal, assim como a suntuosidade, via de regra, dos Tribunais.
} 
É tão hermeticamente fechado que este capital simbólico é ainda aprendido nos bancos escolares das faculdades de Direito.

Mais uma vez, aproximamo-nos do cariz religioso, Dolzany entende que o linguajar empregado é restrito aos iniciados. Conforme Santana (2016), "são raras as páginas de um processo cautelar, por exemplo, em que não se encontre um periculum in mora, fumus boni iuris ou inaudita altera pars", apenas para exemplificar algumas das expressões latinas utilizadas, mas sem olvidar das escritas em idioma nacional, mas que fogem ao entendimento do público em geral. Deve-se compreender que o uso rebuscado da escrita não se consubstancia, necessariamente, em técnica jurídica, mas sim em reafirmação do poder, que visa a manutenção do capital simbólico. O que se está discutindo é o distanciamento que o rigor provoca em relação aos utentes do Poder Judiciário e a consequente dificuldade de assimilação dos pronunciamentos, aqui especificamente, judiciais por parte deste mesmo público, compreendendo como mais um obstáculo ao pleno acesso à Justiça e nítida forma de manutenção do capital simbólico e modo efetivo de controle social, seguindo o entendimento de Pierre Bourdieu (2005).

O público que se utiliza do Poder Judiciário para resolução de seus conflitos, não é sujeito do discurso (tanto que as peças processuais são escritas sempre na terceira pessoa), mas objeto do mesmo. Travestido de neutralidade, de abstração, o capital simbólico do discurso jurídico é esperado pela mesma sociedade da qual se distancia. Neste sentido, expõe Bourdieu (2005, p. 216):

\footnotetext{
Esta retórica da autonomia, da neutralidade e da universalidade, que pode ser o princípio de uma autonomia real dos pensamentos e das práticas, está longe de ser uma simples máscara ideológica. Ela é a própria expressão de todo o funcionamento do campo jurídico e, em especial, do trabalho de racionalização [...] que o sistema das normas jurídicas está continuamente sujeito, e isto há séculos.
}

Da mesma forma que o discurso jurídico se distancia da sociedade, esta também compreende e espera este distanciamento. O poder imbuído no Poder Judiciário, um dos pilares da República, já produziu raízes na própria sociedade. O Estado Leviatã não é um igual, não é um ente que partilha das emoções, dos sentimentos, do linguajar. 
Quanto mais impenetrável, mais poder se incorpora e se (auto)reflete na sociedade. Concordase com Santana ${ }^{8}$ que aduz que "a comunicação deve ser eficaz, essencialmente no contexto jurídico, para que atinja sua finalidade. Não há de se falar em justiça social se o discurso jurídico não é inteligível e ainda, inacessível, segregado". O capital simbólico do discurso jurídico distante do social não é para ser compreendido; é para ser poder, no sentido de submissão dos súditos (membros da sociedade que necessitam do Estado Juiz). Santana (2016) preocupa-se em demonstrar como o rigor do linguajar jurídico muitas das vezes coloca em risco até a própria ordem proferida pelos tribunais (incompreensíveis até para os “iniciados”), e cita o caso do juiz Ricardo Roesler (de Santa Catarina) que ao determinar a prisão de um sujeito proferiu a seguinte decisão: “'Encaminhe o acusado ao ergástulo público”, no entanto, passados dois dias da decisão, a mesma ainda não havia sido cumprida e simplesmente porque ninguém sabia o que ou onde, no caso, era ergástulo (cadeia). A partir deste momento, este juiz, que mais tarde veio a se tornar o presidente da Associação dos Magistrados Catarinenses, passou a defender o uso de linguagem mais simples nos tribunais. Neste sentido, a Associação dos Magistrados Brasileiros (AMB) tem realizado campanhas junto aos seus membros, para sensibilizar pelo uso de palavras menos eruditas, mais acessíveis. No entanto, Sílvia Mara de Melo (2013), apesar de louvar iniciativas como estas, afirma que

A linguagem jurídica irá transformar-se a partir de novas práticas discursivas, quando
sujeitos menos afetados pelo rebuscamento do jurídico se constituírem enquanto
sujeitos produtores de conhecimento jurídico. Uma língua só se modifica
paulatinamente na relação que o sujeito mantém com a língua na história.

Com relação ao questionário apresentado pela via online, das 65 pessoas entrevistadas, 59 pessoas já tiveram acesso a algum tipo de ato judicial, sendo que 28 (44\% da amostra) só conseguiram compreender o conteúdo das decisões após algum tipo de ajuda, recurso ao dicionário ou a algum advogado (dessas 65 pessoas, 22 eram do meio jurídico e não tiveram qualquer tipo de problema de entendimento).

\footnotetext{
${ }^{8}$ SANTANA, S. B. P. A linguagem jurídica como obstáculo ao acesso à justiça. Uma análise sobre o que é o Direito engajado na dialética social e a consequente desrazão de utilizar a linguagem jurídica como barreira entre a sociedade e o Direito/Justiça. In: Âmbito Jurídico, Rio Grande, XV, n. 105, out 2012. Disponível em: <http://www.ambito-juridico.com.br/site/?n_link=revista_artigos_leitura\&artigo_id=12316>. Acesso em 10 de dezembro de 2016.
} 
Apresentaram-se dois trechos de decisões judiciais, um com termos técnicos e outro com expressões rebuscadas. No primeiro caso, 25 pessoas (38\%) afirmaram que conseguiriam entender o excerto caso recebessem explicação técnica, sendo que 18 (28\%) entenderam por serem da área jurídica. Com relação ao trecho apresentado de forma mais pomposa, 30 pessoas (47\%) afirmaram que compreenderiam a decisão com a ajuda de alguém da área jurídica, passando para 8 (13\%) aqueles que entenderam por integrarem o Poder Judiciário de algum modo. Neste aspecto, é possível observar que realmente o dizer do campo jurídico é dirigido eminentemente aos iniciados, aqueles que já compõem o Poder Judiciário, pois as pessoas conseguem entender o texto ou por pertencerem a este segmento social ou por recorrerem a quem pertença. No entanto, é interessante verificar que quando o trecho selecionado é com léxico rebuscado, nem mesmo os da área jurídica compreendem, passando de 18 pessoas (35\%) para $8(13 \%)$. Sobre o distanciamento porventura provocado, os entrevistados ( 51 pessoas, correspondendo a $78 \%$ da amostra) entendem também que a forma muito técnica afasta as pessoas do Poder Judiciário, passando para 55 pessoas (85\%), quando a escrita é erudita. Fica claro que a forma própria de dizer o Direito é mais um obstáculo ao acesso à Justiça.

\section{Pronunciamentos judiciais em versos}

Poesia é um gênero literário composto por versos estruturados e, segundo Luis García Montero, "é um ajuste de contas com a realidade" e é com a realidade que o Poder Judiciário lida continuamente. No entanto, como afirmado acima, a forma de dizer própria do campo jurídico, afasta o seu utilizador, mantendo assim seu capital simbólico, seu poder dentro de uma das facetas do Leviatã. E quando o ato judicial é proferido em versos? A estrutura de poder exercida pelo Poder Judiciário se altera? O rigor do modo próprio de dizer do campo jurídico se quebra ou ao menos se suaviza?

Há, afinal, uma maior compreensão pelos utentes do Poder Judiciário acerca dos assuntos que lhes dizem respeito? Nesta medida, o acesso à Justiça fica facilitado? Responderei a estas questões trazendo alguns pronunciamentos judiciais proferidos em versos, aos quais passarão a ser analisados, cabendo antes apontar que $49 \%$ da amostra entrevistada entende que as decisões em versos são interessantes, seguido daqueles (40\%) que entendem que o Poder Judiciário não 
deve alterar a sua forma de dizer o Direito.

Vejamos a decisão proferida pelo Juiz Rubens Sérgio Salfer, no ano de 2003, em São Miguel do Oeste, em Santa Catarina, na qual julgou improcedente uma ação indenizatória (processo n. ${ }^{\circ}$ 067.01.002.772-2) promovida por um colono contra o outro, tendo em conta que dois porcos de sua criação morreram. Não foram apresentadas provas suficientes para a condenação. Assim foi a sentença em versos:

Visto e analisado

Todo o processado

Os relatórios são dispensados

Conforme a Lei dos Juizados.

Abrão Prestes dos Santos é agricultor Gilmar Henzel tem o mesmo labor São vizinhos na Linha Cordilheira Bem próximo à fronteira.

O primeiro é o reclamante

Vem a Juízo confiante

Propor ação de cobrança

Em face da vizinhança.

Diz o requerente

Que se encontra descontente

Por ver mortos dois suínos

Por afiados dentes caninos.

Os porcos estavam pastando

Não viram o cão chegando

Mal eles sabiam

Que o entardecer não veriam.

Cada um dos animais

Pesava 25 quilos totais

Peso bruto como afirma

A peça inicial confirma.

O segundo é o reclamado

Dono do cão apontado

Causador destas intrigas

Entre famílias amigas.

Sobreveio o despacho inicial

$\mathrm{Na}$ forma da Lei Especial

Citando-se o requerido

Intimando-se o ofendido.

Chega o momento esperado

Pelo juiz designado

Para julgar a questão
Tomados os depoimentos pessoais

$\mathrm{Na}$ forma dos textos legais

Ouvidos dois testigos

Sem quaisquer fustigos.

Apresentadas as razões derradeiras

Tudo sem brincadeiras

Prolato esta sentença

Para geral sabença.

Expressa o artigo trezentos e trinta e três

Em casos deste jaez

Que incumbe ao autor

Evidenciar o seu clamor.

Os testemunhos colhidos

Neste Juízo ouvidos

Vieram em socorro

Do mencionado cachorro.

Os porquinhos coitados

Morreram estraçalhados

Sem que ninguém apontou

Qual bichano lhes matou.

Compete a quem alega

Em caso de refrega

Provar o que sustenta

$\mathrm{Na}$ liça que ostenta.

Princípio não observado

Pelo reclamante desorientado

Provas que não fez

Quando chegou a sua vez.

Sem medos em minha mente

Julgo improcedente

O pedido formulado pelo autor

Lamentando a sua dor.

Sem honorários ou custas

Nestas lides mais que justas

Onde se busca o Direito 
Posta em discussão.

Presentes os patronos

Além dos dois colonos

Proposta a conciliação

Houve sua rejeição.

Apresentada defesa escrita

No feito que tramita

Dizendo que o autor mente

Sendo o réu inocente.
Desde que se prove o pleito.

São Miguel do Oeste

Não fica no Norte, Sul ou Leste

Não fica na Argentina

Fica em Santa Catarina.

Rubens Sérgio é o meu nome

Salfer o sobrenome

Sou Juiz de Direito

Judicando escorreito.

Observe que não é por estar em versos a decisão, que o Juiz deixa de atentar aos requisitos essenciais e legais exigidos. Caso o faça, estará a sentença sujeita à nulidade. Nesta decisão, o Juiz não fez o relatório, porque a lei que regula o Juizado Especial assim admite. Nota-se ainda o emprego a termos rebuscados e fora do uso regular da língua (testigos/fustigos/jaez/liça/escorreito), que fazem com que o destinatário da decisão não a compreenda, sem auxílio a algum meio (advogado, dicionário), mantendo, portanto, o jurisdicionado afastado da percepção livre de decisão que lhe diz respeito. Em 2009, a Juíza Marlene Marlei de Souza, da $2^{\text {a }}$ Vara Cível da Comarca de Carazinho (Rio Grande do Sul), em uma ação de usucapião (processo n. ${ }^{\circ}$ 009/1.06.0006967-7), proferiu a sentença em versos que se segue:

A sobrar-lhe a razão,

Aduz a sua pretensão,

Com respeito vem pedi-la

E a justiça ouvi-la.

Gleba que traz ocupada,

No tempo somente sua,

Em pleno gozo e uso, deseja usucapi-la.

\section{Lá do PINHEIRO MARCADO}

Traz mapa e confrontações, Informa seus lindeiros, Seus vizinhos primeiros. Ouvidos os conhecidos, E também os ausentes, Que receberam citações, Em formais publicações.

E todas FAZENDAS PÚBLICAS,

Município, Estado e União,

Tiveram sua citação.

Em trâmites pertinentes,

No rigor das leis vigentes,

E sem objeção nenhuma,

Nem controvérsia alguma,

Se quedaram silentes.
Intervém a PROMOTORA

com sua ação lutadora,

Em seu agir vigilante,

Em seu ofício bastante

Ativo e competente,

A todos os atos presente,

Concordando plenamente

Com o direito do autor.

A Posse, sempre mansa, prova o autor, não se cansa, Cultivar o amado chão, De onde vem o seu pão E o sustento para os seus, Com a dádiva de DEUS,

$\mathrm{E}$ a aração diária

Hoje, mais que vintenária.

Diante de todo o exposto, de acordo com a lei vigente, julgo, então, procedente, o pedido formulado, ficando todos intimados, da presente decisão. Registre-se, por ocasião, De transitar em julgado. 
Se direitos existentes, CURADORA sua voz diária, Guarida se necessária. Testemunhas convocadas, Informaram compromissadas, Pelo juízo ouvidas, A posse sempre mantida, Mansa, também vintenária
Dezessete, o dia que se move.

Setembro, dois mil e nove.

MARLENE MARLEI DE SOUZA,

Magistrada de Direito,

Em jurídico e justo caminho

Na Querência de Carazinho,

Deu ao seu Sebastião,

A propriedade de seu quinhão!

Interessante observar que, neste processo, tanto o advogado do autor da ação quanto a Defensora Pública, bem como a Promotora de Justiça, todos pronunciaram-se em versos. Voltando à análise da decisão, observa-se o mesmo recurso a um léxico rebuscado (lindeiros/aração), sendo, no entanto, mais frequente os termos técnicos, ocorrendo o mesmo na sentença proferida, em 2015, pelo Juiz Zacarias Leonardo, da $4^{\text {a }}$ Vara Cível de Palmas (Tocantins), na ação de exceção de competência (Processo n. ${ }^{\circ}$ 503086683.2013.827.2729), promovida por uma seguradora contra o motociclista, seu cliente:

Em versos e jurisprudências responde o excepto;

Não pode ser acolhida a exceção; acertado pontua;

O juízo competente é do domicílio do autor ou do local do fato;

Esqueceu-se a excipiente não ser escolha sua.

A lei contemplou o domicílio do autor ou o local do acidente;

Assim é mais fácil para a vítima do sinistro pensou o legislador;

Em sua casa, com sua gente ou onde se feriu o requerente;

Pareceu mais propício buscar lenitivo e reparo à sua dor;

Mas, onde mora o requerente? Perquire o judicante;

Mora em Palmas e se feriu quando no interior se encontrava;

Em seu parágrafo único o artigo cem (100)

soluciona o embate;

O foro do domicílio do autor era escolha que bastava.

\author{
A contestação não parece de canastrão; \\ Pelo contrário, sem respaldo legal e sem \\ assento; \\ Parece, isto sim, a exceção, uma medida de \\ protelação; \\ Coisa de instituição financeira querendo \\ ganhar tempo. \\ De fato a jurisprudência é de remanso; \\ Por outro lado a legislação é de meridiana \\ clareza; \\ Enquanto o requerente espera ansioso o \\ desfecho; \\ Navega tranquila a seguradora sob o \\ benefício da destreza. \\ É preciso colocar na espera um ponto final; \\ Por isso, sem mais delongas, porque não \\ sou poeta; \\ Firmo de logo a competência do juízo da \\ capital; \\ É aqui que se deve resolver o quanto o caso \\ afeta.
}

Das 65 pessoas entrevistadas, 44\% delas entendem que, apesar da decisão ser mais compreensível, ainda assim o Poder Judiciário se mantém afastado do povo porque continua a usar termos muito técnicos que poucos entendem, seguido de $42 \%$ das pessoas que entendem que a decisão não fica mais compreensível só por estar em versos. Nota-se assim que o distanciamento entre o Poder Judiciário e o povo permanece e não é por estar em versos o ato 
judicial que traz proximidade ao jurisdicionado. Na verdade, é somente uma forma lúdica de os agentes/atores judiciais tratarem o processo, sem, na verdade, emergir na verdadeira questão, na mais importante delas, que é a inteligibilidade, que traria uma das facetas reais de proximidade do Judiciário com o povo, garantindo uma das formas de maior acesso ao Direito.

Em 1987, na cidade de Carmo da Cachoeira, o Juiz Ronaldo Tovani, proferiu a decisão em versos que concedeu liberdade provisória a Alceu da Costa (Processo n. ${ }^{\circ}$ 3.069/87), na ocasião preso em flagrante pelo furto de duas galinhas:

No dia cinco de outubro

Do ano ainda fluente

Em Carmo da Cachoeira

Terra de boa gente

Ocorreu um fato inédito

Que me deixou descontente

O jovem Alceu da Costa

Conhecido por Rolinha.

Aproveitando a madrugada

Resolveu sair da linha

Subtraindo de outrem

Duas saborosas galinhas.

Apanhando um saco plástico

Que ali mesmo encontrou

$\mathrm{O}$ agente muito esperto

Escondeu o que furtou

Deixando o local do crime

Da maneira como entrou.

O senhor Gabriel Osório

Homem de muito tato

Notando que havia sido

A vítima do grave ato

Procurou a autoridade

Para relatar-lhe o fato.

Ante a notícia do crime

A polícia diligente

Tomou as dores de Osório

E formou seu contingente

Um cabo e dois soldados

E quem sabe até um tenente.

Assim é que o aparato

Da Polícia Militar

Atendendo a ordem expressa

Do Delegado titular

Não pensou em outra coisa

Senão em capturar.

E depois de algum trabalho

O larápio foi encontrado
Desde quando furto é crime

Neste Brasil de bandidos?

Ante tão forte argumento

Calou-se o delegado

Mas por dever do seu cargo

O flagrante foi lavrado

Recolhendo à cadeia

Aquele pobre coitado.

E hoje passado um mês

De ocorrida a prisão

Chega-me às mãos o inquérito

Que me parte o coração

Solto ou deixo preso

Esse mísero ladrão?

Soltá-lo é decisão

Que a nossa lei refuta

Pois todos sabem que a lei

É prá pobre, preto e puta.

Por isso peço a Deus

Que norteie minha conduta.

É muito justa a lição

Do pai destas Alterosas.

Não deve ficar na prisão

Quem furtou duas penosas,

Se lá também não estão presos

Pessoas bem mais charmosas,

Como das fraudes do governo que até hoje rola.

Afinal não é tão grave

Aquilo que Alceu fez

Pois nunca foi do governo

Nem sequestrou o Martinez

E muito menos do gás

Participou alguma vez.

Desta forma é que concedo

A esse homem da simplória

Com base no CPP

Liberdade provisória 
Estava no bar do Pedrinho" Quando foi capturado Não esboçou reação Sendo conduzido então À frente do Delegado.

Perguntado pelo furto Que havia cometido Respondeu Alceu da Costa Bastante extrovertido
Para que volte para casa

E passe a viver na glória.

Se virar homem honesto

E sair dessa sua trilha

Permaneça em Cachoeira

Ao lado de sua família

Devendo, se ao contrário,

Mudar-se para Brasília.

Das decisões analisadas, esta foi a única na qual o juiz não utilizou termos rebuscados e nem mesmo tão técnicos, guardando respeito, ainda assim, aos requisitos exigidos por lei, sendo mais facilmente compreendida pelo público em geral.

De um modo geral, as sentenças em versos constituem um modo diverso de apresentação da escrita regular e típica do campo jurídico, mas ainda assim, por mais palatável que seja, conforma-se e dirige-se de modo endógeno, para os iniciados do Poder Judiciário, mantendo seu capital simbólico e a sua estrutura de poder, pois como afirma Norman Fairclough (2003) a linguagem, por meio do discurso, enquanto prática social, está relacionada com a dominação. No entanto, o conhecimento desta sujeição traz uma consciência que leva à emancipação, sendo esta a proposta da análise crítica do discurso e, por meio dela, verificamos que todas as estruturas e narrativas de poder estão ainda lá, nos atos judiciais em verso, não obstante a mudança lúdica da forma de apresentação dos atos judiciais. Por fim, cumpre apenas ressaltar que os atores judiciais que proferiram atos judiciais em versos não o fazem como prática habitual, tendo sido apenas pontual, o que pode revelar ainda mais a forma lúdica e não uma forma de acessibilidade ao Direito, à Justiça.

\section{Considerações finais}

Todo pronunciamento judicial corresponde a um discurso e, neste sentido, uma prática social. Como afirmado acima, dizer o Direito é fazer o Direito e este deve alcançar a todos, sobretudo aqueles a quem se socorre. Conclui-se que as decisões escritas em verso rompem com o rigor da escrita na sua forma literária e são mais agradáveis de se ler, no entanto, não quebram o capital simbólico existente no Poder Judiciário. O uso de termos técnicos e rebuscados 
continuam a existir, seja proferida em versos ou não a decisão, com raras exceções.

Uma teoria jurídica não deixa de ser teoria e nem mesmo perde seu valor por estar escrita de modo inteligível por aquele que deveria ser seu verdadeiro público (o povo) e não só para os iniciados na ciência jurídica. Continua endógeno o discurso, seja escrito em versos ou não. Manter-se hermeticamente fechada a estrutura e a forma de escrita que é própria do campo jurídico significa conservar o poder, a dominação sobre os súditos do Estado (a qual o Judiciário faz parte), constante afastamento e consequente obstáculo ao acesso ao Direito. As decisões judiciais devem ser mais inteligíveis, devem alcançar seu público para que efetivamente venham a produzir efeito no mundo social, pois se compreenderá com mais facilidade o que está decidido e o verdadeiro sentido da mesma, provocando maior adesão, cumprindo mais facilmente o Poder Judiciário seu papel e função social. Na verdade, um Judiciário mais próximo significa uma sociedade mais forte, devolvendo assim o princípio primeiro estabelecido na Constituição Federal de 1988: "Todo poder emana do povo" (parágrafo $1^{\circ}$, do artigo $1^{\circ}$ da Carta Magna). Ou será precisamente isso que o Poder Judiciário teme? 


\section{Referências bibliográficas}

BOURDIEU, Pierre. O poder simbólico. Tradução Fernando Tomaz. (Coleção memória e sociedade). Rio de Janeiro: Bertrand Brasil, 2005.

BRITO, D. T. Linguagem: o poder no discurso jurídico. Diálogo e interação. Vol. 1. ISSN 2175-3687. 2009. Disponível em http://www.faccrei.edu.br/wpcontent/uploads/2016/10/diartigos14-1.pdf. Acesso em 20 de dezembro de 2016.

DOLZANY, M. a comunicação e o acesso à Justiça. R. CEJ, Brasília, n. 22, p. 13-19, jul./set. 2003.

FAIRCLOUGH, N. Discurso e mudança social. Brasília: Universidade de Brasília, 2001.

FAIRCLOUGH, N. El análisis crítico del discurso como método para la investigación en ciencias sociales. In: WODAK, Ruth; MEYER, Michel (eds.). Métodos de análisis crítico del discurso. Barcelona: Gedisa, 2003, p. 179-203.

FOUCAULT, M. Vigiar e Punir. 20ª edição. Petrópolis: Editora Vozes. 1999.

FOUCAULT, M. Microfísica do Poder. 4ª edição. Rio de Janeiro: Edições Graal. 1984

GERSZTEIN, P. C. O Direito fundamental de acesso à Justiça na perspectiva luso-brasileira. RIDB, ano 2, n. ${ }^{\circ}$ 9, SSN: 2182-7567. 2013. Disponível em http://www.cidp.pt/publicacoes/revistas/ridb/2013/09/2013_09_09421_09496.pdf. Acesso em 12 de dezembro de 2016.

MAINGUENEAU, D. Novas Tendências em Análise do Discurso. Campinas: Ed. UnicampPontes, $2^{a}$ ed., 1993.

MAINGUENEAU, D. Gênese dos discursos. Tradução Sírio Possenti. São Paulo: Parábola Editorial, 2008.

MELO, S. M. de. As formações discursivas jurídicas: uma questão polêmica. Ling. (dis)curso, Tubarão, v. 13, n. 2, p. 225-241, Aug. 2013. Disponível em http://www.scielo.br/scielo.php?script=sci_arttext\&pid=S1518- 
$76322013000200002 \& \operatorname{lng}=$ en\&nrm=iso. Acesso em 20 de dezembro de 2016. http://dx.doi.org/10.1590/S1518-76322013000200002.

OLIVEIRA, M. B. F. Pensando a escrita como uma prática discursiva: implicações para a pesquisa em LA. Rev. bras. linguist. apl., Belo Horizonte , v. 3, n. 1, p. 117-131, 2003

. Disponível em <http://www.scielo.br/scielo.php?script=sci_arttext\&pid=S1984$63982003000100008 \& \operatorname{lng}=e n \& n r m=i s o>$. Acesso em 19 de dezembro de 2016. http://dx.doi.org/10.1590/S1984-63982003000100008.

PERELMAN, C. Lógica jurídica. Tradução Vergínia K. Pupi. $2^{\text {a }}$ ed., São Paulo: Martins Fontes, 2004.

ROCHA, D.; DEUSDARÁ, B. Análise de Conteúdo e Análise do Discurso: aproximações e afastamentos na (re)construção de uma trajetória. Alea, Rio de Janeiro, v. 7, n. 2, p. 305322, Dec. 2005 . Disponível em

$<$ http://www.scielo.br/scielo.php?script=sci_arttext\&pid=S1517106X2005000200010\&lng=en\&nrm=iso >. Acesso em 18 de dezembro de 2016. http://dx.doi.org/10.1590/S1517-106X2005000200010.

ROCHA, L. A. G. S. A Escola Francesa e as Definições de Poder: Georges Burdeau e Michel Foucault. Revista Mestrado em Direito (UNIFIEO. Impresso), v. 10, p. 97-113, 2010

RODRIGUES, M. S.; DELLAGNELO, E. H. L. Do discurso e de sua análise: reflexões sobre limites e possibilidades na Ciência da Administração. Cad. EBAPE.BR, Rio de Janeiro, v. 11, n. 4, p. 621-635, Dec. 2013. Available from

$<$ http://www.scielo.br/scielo.php?script=sci_arttext\&pid=S1679-

$39512013000400010 \& \operatorname{lng}=\mathrm{en} \& \mathrm{nrm}=\mathrm{iso}>$. access

on 15 Dec. 2016. http://dx.doi.org/10.1590/S1679-39512013000400010.

SANTANA, S. B. P. A linguagem jurídica como obstáculo ao acesso à justiça. Uma análise sobre o que é o Direito engajado na dialética social e a consequente desrazão de utilizar a linguagem jurídica como barreira entre a sociedade e o Direito/Justiça.. In: Âmbito Jurídico, Rio Grande, XV, n. 105, out 2012. Disponível em: <http://www.ambitojuridico.com.br/site/?n_link=revista_artigos_leitura\&artigo_id=12316>. Acesso em $10 \mathrm{de}$ dezembro de 2016. 
TOMAZI, M. M. \& MARINHO, J. H. C. Discurso jurídico e relações de poder: gestão de faces e de lugares. Revista (Com)Textos Linguísticos. Vol. 8, n.10.1. 2014. Disponível em http://www.periodicos.ufes.br/contextoslinguisticos/article/view/8362/6060. Acesso em $12 \mathrm{de}$ dezembro de 2016.

WODAK, R. De qué trata el análisis crítico del discurso. Resumen de su historia, sus conceptos fundamentales y sus desarrollos. In: ——; MEYER, M. (orgs.). Métodos de Análisis Crítico del Discurso. Barcelona: Gedisa, 2003, p. 17-34.

\section{Referências das sentenças}

Disponível em http://veja.abril.com.br/blog/radar-on-line/inspirado-juiz-profere-sentenca-emverso-2/

Disponível em http://noticiasdoslencois.blogspot.pt/2009/05/sentenca-em-verso_31.html Disponível em http://mundocordel.com/livro-sentencas-em-versos/

Disponível em http://www.migalhas.com.br/Quentes/17,MI223042,71043- Disponível em Advogado+peticiona+em+versos+e+juiz+decide+em+prosa+e+poesia

Disponível em http://www.migalhas.com.br/Quentes/17,MI93318,71043- Disponível em Sentenca+e+proferida+em+versos+na+primeira+Audiencia+Crioula+de 


\section{O (in)efetivo acesso à justiça no emprego público}

\section{The (in)effective access to justice in public employment law}

\author{
Ana Rita Mesquita Babo Teixeira Pinto; \\ 1E-mail: babo.ana14@gmail.com \\ Técnica Superior Jurista| \\ Banco de Portugal
}

Resumo: Qualquer relação jurídico-laboral com vínculo de emprego público comporta, sempre, para ambos os contraentes, uma complexidade de direitos e obrigações, à semelhança do que acontece no direito privado. Neste tipo de relações jurídicas, o acesso aos tribunais torna-se fulcral até porque, muitas vezes, poderácolocar-se em causa o respeito por direitos fundamentais. Daí que neste ramo do direito, o acesso à justiça tenha que ser, acima de tudo, efetivo. Alcançaremos uma justiça efetiva, de maior qualidade, se as pretensões trazidas a juízo forem julgadas por tribunais especializados, com recursos humanos vocacionados e sensibilizados para determinado tipo de questões jurídicas. E será isso que efetivamente acontece nos litígios que emergem das relações públicolaborais? Serão os tribunais administrativos e fiscais os mais competentes para os conhecer, dirimir e julgar? Ou, pelo contrário, serão os juízos de trabalho mais capazes e competentes para lidar com estas matérias?

Palavras-chave: emprego público; justiça efetiva; competência dos tribunais; conflitos de jurisdição.

Abstract: Any public employment relationship contains, for both parts, a complexity of rights and duties (as it happens in the private labor sector). In these type of relationships, the access to justice becomes essential, particularly because litigation may involve fundamental rights violations'. In this area of law, the access to justice needs to be especially effective. To be more effective and provide better judgments, the litigation may be ruled by specialized courts with human resources aimed to judge specific legal issues. Is this what happens in the Portuguese legal proceedings that emerge from the public employment law? Are the Portuguese administrative courts the most competent ones to judge the litigation related to public employment? Or, in contrast, are labor courts more qualified to deal with these issues?

Keywords: public employment; effective justice; court jurisdiction; conflicts of jurisdiction. 


\section{Introdução}

Qualquer relação jurídica laboral (seja de natureza pública ou privada) comporta sempre, para ambos os contraentes (empregador/entidade pública e colaborador/colaborador com vínculo de emprego público), uma complexidade de obrigações e direitos. Este tipo de relação jurídicaacaba por incidir, grande parte das vezes, sobre direitos fundamentais, ${ }^{1}$ desde o mais básico direito à segurança no emprego, ${ }^{2}$ ao direito ao trabalho. ${ }^{3}$

Consequentemente, o acesso aos tribunais ${ }^{4}$ torna-se fulcral e a via mais adequada para uma defesa sólida e robusta perante violações de direitos fundamentais, tal como reconhecem Gomes Canotilhoe Vital Moreira (2014, p. 408) "O direito de acesso ao direito e à tutela jurisdicional efetiva ( $n^{o} 1$ e epigrafe) é, ele mesmo, um direito fundamental constituindo uma garantia imprescindível de proteção de direitos fundamentais, sendo, por isso, inerente à ideia de Estado de direito". Este acesso ao direito tem que se traduzir numa justiça efetiva. Ora, essa efetividade pode manifestar-se sob os mais variados aspetos. Um deles é, sem dúvida, serem proferidas sentenças adequadas às pretensões de tutela deduzidas em juízo. Na verdade, alcançaremos uma justiça de maior qualidade se as pretensões trazidas a juízo forem julgadas por tribunais especializados e com recursos humanos vocacionados e sensibilizados para determinado tipo de questões jurídicas. E será isso que efetivamente acontece nos litígios emergentes do direito de emprego público? Ao refletir sobre estão questão, deparamo-nos com alguns problemas que surgem nesta área e que pretendemos ver aqui tratados, equacionados e refletidos. Nomeadamente, questionamo-nos se serão os tribunais administrativos e fiscais (TAF) os mais competentes para conhecer de litígios emergentes de relações laborais no âmbito do emprego público. Ou, pelo contrário, até que ponto a justiça alcançaria decisões mais razoáveis se fossem os juízos de trabalho a conhecer e julgar estas matérias?

\section{A Lei Geral do Trabalho em Funções Públicas: principais alterações}


A Lei ${ }^{\circ}$ 35/2014, de 20 de junho, denominada Lei Geral do Trabalho em Funções Públicas (daqui em diante LGTFP), trouxe inúmeras mudanças para o direito do emprego público. Sem dúvida que a primeira alteração passa pela nova sistematização das matérias. A LGTFP possui um "intuito marcadamente agregador, no sentido de que pretende reunir num único diploma temáticas até agora dispersas por diversas diplomas” (Miguel Lucas Pires, 2016, p.5). Mais do que isso, a LGTFP também pretendeu integrar e contemplar as alterações legislativas realizadas no regime laboral da função pública,que, entretanto, o haviam descaracterizado por completo, devolvendo e reforçando também neste aspeto, a sua sistematização, unidade e coerência. Isso mesmo foi reconhecido na exposição de motivos da Proposta de Lei n. ${ }^{\circ}$ 184/XII, "A complexidade e proliferação de diplomas que regulam o regime de trabalho em funções públicas bem como as alterações avulsas e sucessivas de que o mesmo foi objeto[...] criaram um edifício legal que se vira contra a própria Administração Pública" que "propicia a conflituosidade jurídica, em grande parte derivada do seu carácter disperso e fragmentado, gerador de incerteza e insegurança na aplicação do direito."

Em segundo lugar importa destacar que a LGTFP pretendeu também tomar como "modelo de vínculo de emprego público a figura do contrato de trabalho em funções públicas, sem deixar de procurar um regime unitário para as duas grandes modalidades de vínculo de emprego (contrato e nomeação), realçando apenas as especificidades de cada uma sempre que necessário"(Cláudia Sofia Henriques Nunes, 2014, p.12).Sobre isso há que dar algumas notas breves, mas importantes.

O vínculo do emprego público é definido, no número 2 do artigo $6^{\circ}$ da LGTFP, como aquele pelo qual uma pessoa singular presta a sua atividade a um empregador público, de forma subordinada e mediante remuneração, podendo ser constituído por um tempo indeterminado ou a termo resolutivo. ${ }^{5}$ A par do contrato de trabalho, encontramos como modalidades de constituição do vínculo de emprego público, a nomeação e a comissão de serviço, ${ }^{6}$ com a diferença do primeiro, ao contrário dos restantes, se consubstanciar num ato bilateral celebrado entre um empregador público (com ou sem personalidade jurídica, agindo em nome e representação do Estado) e um particular, nos termos do qual se constitui uma relação de trabalho subordinado.

Decorre agora expressamente do artigo $7^{\circ}$ da LGTFP que "O vínculo do emprego público constitui-se, em regra, por contrato de trabalho em funções públicas”. Mantém-se assima tendência criada pela Lei dos Vínculos, Carreiras e Remunerações (LVCR), ${ }^{7}$ que introduziu 
uma mudança radical no regime do emprego público já que, até à sua entrada em vigor, a nomeação era a modalidade mais frequente de constituição de vínculo de emprego público. Acontece que a LGTFP não identifica, ao contrário do que sucede com a nomeação e a comissão de serviço, que funções públicas devem ser desempenhadas ao abrigo da celebração de um contrato de trabalho em funções públicas.

Pelo que, a sua constituição ainda que seja atualmente regra geral,acaba por ser atribuída subsidiariamente, o mesmo é dizer, será celebrado um contrato de trabalho em funções públicas, sempre que os trabalhadores não tenham sido nomeados ou não estejam abrangidos por uma comissão de serviço.

E quando é que as funções públicas têm que ser exercidas por nomeação ou comissão de serviço? A isso nos respondem os artigos $8^{\circ}$ e $9^{\circ}$ da LGTFP.

O artigo $8^{\circ}$ da LGTFP enumera as situações em que o vínculo de emprego público se constitui por nomeação: missões genéricas e específicas das Forças Armadas em quadros permanentes; representação externa do Estado; informações de segurança; investigação criminal; segurança pública quer em meio livre quer em meio institucional e inspeção.

O artigo $9^{\circ}$ da LGTFP enumera as situações em que o vínculo de emprego público se constitui por comissão de serviço: cargos não inseridos em carreiras, designadamente cargos dirigentes e funções exercidas com vista à aquisição de formação específica, habilitação académica ou título profissional por trabalhador com vínculo de emprego público por tempo indeterminado. Concluindo, fora dos casos previstos nos artigos $8 .^{\circ} \mathrm{e} 9 .^{\circ}$ da LGTFP, será celebrado um contrato de trabalho em funções públicas, respeitando-se assim, a regra geral prevista no artigo $7 .^{\circ}$ do mesmo diploma.

\section{A aproximação do regime do contrato de trabalho em funções públicas ao regime do Código de Trabalho}


O contrato de trabalho em funções públicas, o referido regime regra, também sofreu importantes alterações com a entrada em vigor da LGTFP.

$\mathrm{Na}$ verdade, é opinião unânime que outra das grandes alterações da LGTFP consiste na “convergência tendencial do regime dos trabalhadores públicos com o regime dos trabalhadores comuns, ressalvadas as especificidades exigidas pela função e pela natureza pública do empregador, com salvaguarda do estatuto constitucional da função pública" (Cláudia Nunes, 2014, p.11).

Prova disso é a LGTFP remeter diretamente a disciplina de algumas matérias para o Código do Trabalho, tornando este diploma fonte subsidiária do contrato de trabalho em funções públicas. E fá-lo de duas formas. Por um lado, através do artigo $4^{\circ}$ da LGTFP cuja epígrafe é, sem mais, “Remissão para o Código de Trabalho”, consagrando uma remissão geral para o Código do Trabalho (doravante CT) nas matérias que o próprio artigo elenca (e que são muitas!).

Acresce que, e como diz Cláudia Nunes (2014, p.12), “A L[G]TFP apenas reservou um regime próprio para as matérias que, devido às especificidades exigidas pela função e pela natureza pública do empregador, exigiam um tratamento diferenciado do regime privado". ${ }^{8}$ Ou seja, a aplicação das disposições do CT, ao abrigo desse artigo, não terá uma aplicação excecional, como à partida poderia parecer, mas aplicar-se-á, em grande parte das matérias constantes da LGTFP, conforme se pode ver pelas alíneas que enriquecem o referido artigo $4 .^{\circ}$ Por outro lado, e para além da remissão geral constante já do artigo 4. ${ }^{\circ}$ da LGTFP, existem normas remissivas, dispersas e espalhadas, ao longo de toda a LGTFP - ex. artigo $16 .^{\circ}, 25 .^{\circ}$, 56. ${ }^{\circ}, 101 .^{\circ}, 122 .^{\circ}, \ldots$

Apesar da aproximação clara entre estes dois regimes, quer pela consagração da remissão geral do artigo $4^{\circ}$ da LGTFP, quer pelas restantes normas remissivas dispersas ao longo do diploma, há uma diferença essencial que não foi alterada com a entrada em vigor da LGTFP.

\subsection{A competência dos tribunais administrativos e fiscais para dirimir litígios emergentes da constituição do vínculo de emprego público}


$\mathrm{Na}$ verdade, enquanto os litígios emergentes de relações jurídicas laborais privadas são dirimidos pelos juízos de trabalho; ${ }^{9}$ os litígios laborais emergentes de vínculo de emprego público estão, de acordo com o artigo $12^{\circ}$ da LGTFP, entregues aos TAF, "São da competência dos tribunais administrativos e fiscais os litígios emergentes do vínculo de emprego público." E, na verdade, já antes da entrada em vigor da LGTFP, o artigo 83. ${ }^{\circ}$ da LVCR, previa exatamente essa mesma atribuição de competências aos TAF. ${ }^{10}$

Ora, se o contrato de trabalho em funções públicas é, atualmente, o regime regra, cada vez mais semelhante ao que se encontra previsto no CT (recordemos a extensa remissão do artigo $4 .^{\circ}$ da LGTFP), surgem inevitavelmente preocupações: será razoável esta distinção, quando na prática estamos perante regimes materialmente muito semelhantes? Visto de uma outra perspetiva, encontram-se os TAF preparados para resolver conflitos com uma natureza predominantemente mais laboral do que público-administrativa?

Ciente desta questão esteve também o legislador. Na verdade, para o artigo $12^{\circ}$, até ao penúltimo anteprojeto da LGTFP, estava prevista uma redação completamente diferente da que aqui apresentamos e que foi abandonada na fase da concertação social. A sua redação dispunha que “1. São da competência dos tribunais de trabalho os litígios emergentes do vínculo de emprego público, sem prejuízo do disposto no número seguinte. 2. É da competência dos tribunais administrativos e fiscais a verificação da invalidade de vínculo de emprego público, que diretamente resulte da invalidade do ato administrativo no qual se fundou a constituição ou a modificação do mesmo". Segundo Luís Almeida (2016, p.15), esta proposta foi abandonada "Porque, como assinalou recentemente FAUSTO DE QUADROS, houve uma forte oposição por parte dos membros da comissão da reforma do Código do Processo nos Tribunais Administrativos e do ETAF (já que esta solução divergia em toda a linha daquelas que a comissão pretendia alcançar com a Reforma do Contencioso Administrativo); e porque esta alteração gerou uma forte oposição por parte das estruturas sindicais em sede de concertação social". A redação atual é totalmente diferente, como já foi supra descrito.

Esta questão já foi denunciada na doutrina. Cláudia Nunes (2014, p.18), afirma que "Não obstante a aproximação do regime aplicável aos trabalhadores que exercem funções públicas ao regime laboral privado, os litígios emergentes do vínculo do emprego público continuam a ser resolvidos pelos tribunais administrativos e não, como sucede, nas relações jurídicolaborais privadas, pelos tribunais de trabalho”. Já Luís Almeida (2016, p. 16) sustenta, como soluções a este problema, que "Ou se mantém esta solução dualidade de jurisdição; Ou se 
transfere para a jurisdição administrativa e fiscal todo o Direito Laboral Administrativo, o que inclui todas as relações de trabalho inerentes ao exercício da função administrativa, independentemente dos respectivos estatutos e regimes jurídicos; Ou se transfere para a jurisdição dos tribunais de trabalho os litígios emergentes de vínculo de emprego público, ficando todo o Direito Laboral Administrativo debaixo da Jurisdição Comum." A defender a primeira posição encontramos Pedro Madeira de Brito (2010, p. 496) “é inquestionável que os litígios emergentes das relações de trabalho subordinado na administração pública, constituídas por uma das formas previstas na LGTFP, devem ser submetidas aos tribunais da jurisdição administrativa". A segunda posição é “claramente a solução defendida pela maioria da Doutrina, sendo defendida (de forma mais ou menos clara) por VASCO PEREIRA DA SILVA, VIEIRA DE ANDRADE, PAULO VEIGA E MOURA, ANA NEVES e BETTENCOURT DA CAMARA, e pela CGTP em sede de concertação social (no quadro da discussão do anteprojecto da LGTFP)." (Luís Almeida, 2016, p. 16). Para defesa desta posição são elencados, essencialmente, cinco argumentos: i) conjugação da alínea e) do número 1 do artigo 4. ${ }^{\circ}$ do ETAF com a alínea b) do número 4 do mesmo artigo do ETAF; ii) evitar o esvaziamento do foro administrativo; iii) os TAF serem processualmente mais céleres, na decorrência do respeito das especificidades administrativas e do sistema de organização judiciário; iv) os tribunais comuns proferirem decisões parciais, mais favoráveis aos empregadores e v) a inconstitucionalidade que poderá advir por desrespeito ao artigo $269 .^{\circ}$ da CRP, que traduz a existência de especificidades nas relações de emprego público. Por fim, a terceira posição que consistiria na "transferência de todo o Direito Laboral Administrativo para a jurisdição dos tribunais civis ou tribunais de trabalho, numa lógica em que se realça a natureza laboral dos contratos aqui em causa e em que se faz prevalecer o critério da similitude material das situações contratuais." (Luís Almeida, 2016, p. 19) ${ }^{11}$ é defendida por Palma Ramalho ${ }^{12}$ por ser uma solução que privilegia a i) similitude material das situações, ii) a especialização técnica dos juízos de trabalho para dirimir os litígios emergentes deste tipo de relações e iii) a redução dos conflitos de jurisdição existentes nesta matéria.

Mais do que compreender aquilo que a doutrina tem vindo a defender e as diversas posições existentes quanto a este tema, ${ }^{13}$ importa sobretudo perceber se a solução consagrada na atual LGTFP, que consistiu na manutenção do que já havia sido consagrado na LVCR, tem sido pacificamente aplicada pelos Tribunais. Ou seja, importa não apenas analisar a teoria, mas também aquilo que se tem vindo a registar na prática judicial. 
Para melhor refletir sobre estas questões, analisaremos, de seguida, alguma jurisprudência que demonstra bem as dificuldades por vezes sentidas neste campo e noutros com ele relacionados.

\subsection{As decisões contraditórias que têm surgido na jurisprudência}

A jurisdição dos tribunais judiciais é subsidiariamente definida na ordem jurídica portuguesa, conforme decorre do número 1 do artigo $211^{\circ}$ da CRP - “Os tribunais judiciais são os tribunais comuns em matéria cível e criminal e exercem jurisdição em todas as áreas não atribuídas a outras ordens judiciais." - bem como do número 1 do artigo $130^{\circ}$ da Lei no 62/2013, de 26 de agosto (LOSJ), ${ }^{14}$ ou ainda do artigo $64^{\circ}$ do Código do Processo Civil (CPC). ${ }^{15}$ Consequentemente, podemos dizer que a jurisdição dos tribunais judiciais é também definida por exclusão face aos TAF, ${ }^{16}$ ou seja, havendo normas que expressamente habilitem os TAF a dirimir certo tipo de litígios, serão esses (pelo menos formalmente e por decorrência legal) os tribunais competentes para tal.

Acontece que, apesar de no emprego público existirem normas específicas na legislação ordinária que atribuem competência aos TAF, nomeadamente o já referido artigo $12^{\circ}$ da LGTFP, ao qual devemos acrescentar a alínea b) do número 4 do artigo $4^{\circ}$ do Estatuto dos Tribunais Administrativos e Fiscais (doravante ETAF) "Ficam igualmente excluídas do âmbito da jurisdição administrativa e fiscal: d) A apreciação de litígios decorrentes de contratos de trabalho, ainda que uma das partes seja uma pessoa coletiva de direito público, com exceção dos litígios emergentes do vínculo de emprego público”, ainda assim, surgem na jurisprudência, conflitos de jurisdição negativos. O que não deixa de ser curioso e por isso podemos perguntar: numa questão que, à partida, parece tão bem delimitada (afinal a LGTFP e o ETAF parecem expressamente estipular a competência dos TAF para dirimir os litígios emergentes de vínculos de emprego público), porque será que, ainda assim, surgem tantos conflitos de jurisdição negativos nestas matérias?

$\mathrm{Na}$ verdade, aquilo que se tem vindo a verificar é que os TAF acabam por se considerar incompetentes para dirimir esses litígios porque isso comporta a aplicação de normas laborais, constantes do CT. Por sua vez, os juízos de trabalho, sem normas legais que os habilitem a julgar tais litígios, consideram-se incompetentes para dirimi-los já que, legalmente, essa esfera encontra-se expressamente atribuída aos TAF. 
a) A relevância da configuração pelo Autor da relação jurídico-material e pedido para dirimir estes conflitos de jurisdição

Exemplo disso é o Acórdão do Tribunal Central Administrativo Sul(“TCAS”) de 08 de novembro de 2007, proc. $\mathrm{n}^{\mathrm{o}}$ 00392/04. ${ }^{17}$ Em primeiro lugar o acórdão referido começa por clarificar que o conceito de jurisdição e competência são distintos, sendo possível definir o primeiro como "o poder de julgar genericamente atribuído, na organização do Estado, ao conjunto de tribunais" e o segundo como "a medida de jurisdição legalmente atribuída a cada um dos tribunais". Sabemos também que a competência varia em função de determinados critérios: matéria, valor, hierarquia e território. No caso em apreço importa a competência material.

A competência material dos TAF encontra-se no número 3 do artigo $212^{\circ}$ da CRP, mas também no ETAF, nomeadamente nos seus artigos $1^{\circ}, 3^{\circ}$ e $4^{\circ}$. Ora, para sabermos se a competência é dos TAF ou dos tribunais comuns, importa, em primeiro lugar, relembrar como é que a mesma se afere. Como diria Manual de Andrade (1979, p.91), “A competência do tribunal - ensina REDENTI - "afere-se pelo quiddisputatum (quiddecidendum, em antítese com aquilo que será mais tarde o quiddecisum"), é o que tradicionalmente se costuma exprimir dizendo que a competência se determina pelo pedido do Autor." 18

A competência apura-se então pelo pedido do Autor, não se fazendo qualquer tipo de juízo, nesse momento, acerca do seu mérito. Neste caso, o Tribunal Administrativo de Círculo de Lisboa, na primeira instância, decidiu julgar procedente a exceção de incompetência material porque o Autor não tinha provado a opção pelo regime jurídico de emprego público, ${ }^{19} \mathrm{e}$ baseavao seu pedido do Autor numa relação de natureza laboral de direito privado. Ao intentar a ação na jurisdição comum, também foi julgada procedente a exceção de incompetência material por se considerar que o Autor era um funcionário público e que a natureza da relação jurídica laboral era mista. Para este Tribunal nesses casos deve prevalecer "a natureza do vínculo naquilo que é inerente à natureza do provimento e não o vínculo na sua integralidade."

O Acórdão referido veio apoiar a decisão de incompetência material proferida pela jurisdição comum, concluindo que apesar do regime regra aplicável aos funcionários em causa ser o do direito privado, coexistia, ao mesmo tempo, para funcionários oriundos da Ex-Emissora Nacional, um regime de direito público, que emergia de uma relação jurídica de natureza administrativa. Não tendo isso sido alterado, o Autor mantinha uma relação de emprego público 
e não de direito laboral, pelo que essa relação só interessava "à justiça administrativa as relações jurídicas administrativas públicas, reguladas pelas normas de direito administrativo, passando em regra a determinação da competência por um critério material que assente na distinção material entre o direito público e o direito privado”. No mesmo sentido o Acórdão do Tribunal de Conflitos n. ${ }^{\circ}$ 11/05, de 8 de novembro de 2011, afirmou que "os trabalhadores oriundos da ex-EN, mantêm, um regime de direito público, pelo que deve concluir-se que os litígios relativos a seu estatuto laboral emergem de uma relação jurídica de emprego público e não de uma relação laboral de direito privado."

Noutros Acórdãos, mais recentes, o Tribunal de Conflitos tem vindo a dizer o mesmo:"Se a questão do processo emerge de uma relação jurídica considerada de emprego público, é competente a jurisdição administrativa para apreciar e dirimir o litígio." - Cf. processo n. ${ }^{\circ}$ 056/13, de 16 de janeiro de 2014.

Por sua vez, e mais recentemente, no Acórdão n. ${ }^{\circ}$ 08/14, de 01 de outubro de 2015, o Tribunal de Conflitos concluiu em sentido oposto. Aqui o Autor requer ao Tribunal o reconhecimento da existência de uma relação laboral, regida pelo direito privado, entre si e a Universidade do Porto, ainda que a mesma tenha sido constituída por um contrato administrativo de provimento. E aqui conclui o Tribunal de Conflitos que "perante a pretensão expressa do Autor de reconhecimento da existência de um contrato individual de trabalho e não de uma relação de trabalho em funções públicas, não pode resolver-se a questão da competência em razão da matéria caracterizando tal relação como de contrato de trabalho em funções públicas em função da interpretação da evolução do regime jurídico em sentido contrário ao pretendido pelo Autor (sendo alheia ao objecto da presente decisão, repete-se, qualquer apreciação do acerto dessa solução)." No mesmo sentido ver ainda Acórdão do Tribunal de Conflitos n. ${ }^{\circ}$ 12/15, de 08 de março de 2017, Acórdão do Tribunal de Conflitos n. ${ }^{\circ}$ 017/16, de 17 de novembro de 2016 ou o Acórdão do Tribunal de Conflitos n. ${ }^{\circ}$ 07/17 de 07 de dezembro de 2017, onde se afirma expressamente que "Compete ao juízo do trabalho respetivo conhecer de contrato de trabalho, em funções públicas" já que "Se o autor fundamenta a ação tendo por base, em grande parte, numa relação laboral de direito privado, a competência para o julgamento do litígio, deve ser atribuída à jurisdição comum, por estar este expressamente excluído da jurisdição administrativa. Tanto mais que aos juízos do trabalho compete conhecer, em matéria cível, das questões que vêm elencadas sob as alíneas a) a s) do n. ${ }^{\circ} 1$ do art. 126. ${ }^{\circ}$ da LOSJ, mais concretamente: "b) Das questões emergentes de relações de trabalho subordinado(...); e n) Das questões entre sujeitos de uma relação jurídica de trabalho ou entre 
um desses sujeitos e terceiros, quando emergentes de relações conexas com a relação de trabalho, por acessoriedade, complementaridade ou dependência, e o pedido se cumule com outro para o qual o juízo seja diretamente competente". ${ }^{20}$

\section{b) A extensão da competência dos Juízos de Trabalho}

O Acórdão do Supremo Tribunal Administrativo (doravante "STA"), de 16 de junho de 2015, proc. 117/14.4TTLMG.C1.S1, considera mais uma vez que "A determinação do tribunal materialmente competente radica na estrutura da relação jurídica material submetida à apreciação do tribunal, segundo a versão apresentada pelo autor, isto é, tendo em conta a pretensão concretamente formulada e os respetivos fundamentos."

Sucede que, neste caso, o Autor configura o vínculo estabelecido com a entidade empregadora como um contrato individual de trabalho que, com a entrada em vigor do $\mathrm{n}^{\mathrm{o}} 2$ do art. $17 .^{\circ} \mathrm{da}$ Lei 59/2008, de 11/9, se teria transformado num contrato de trabalho em funções públicas, cujos litígios, como vimos, encontram-se legalmente atribuídos aos TAF.

O Supremo Tribunal Administrativo discordou então da decisão da Relação do Porto que considerou que a relação jurídico-laboral aqui em causa se tinha convolado, a partir de 1 de janeiro de 2009, num contrato de trabalho em funções públicas, isto porque " $E$ certo que o $n^{\circ} 2$ do art. 17. ${ }^{\circ}$ da $n^{o}$ Lei 59/2008, de 11/9, estabeleceu que a transição dos trabalhadores que, nos termos daquele diploma, se deva operar, designadamente das modalidades de nomeação e de contrato individual de trabalho, para a modalidade de contrato de trabalho em funções públicas é feita sem dependência de quaisquer formalidades".

Apesar do Tribunal também acolher como certo que "os Tribunais Administrativos são os competentes para apreciar os litígios emergentes desta relação jurídica de emprego público, norma que entrou em vigor em 01.01.2009, nos termos do preceituado no art. $118 .{ }^{\circ}, n^{\circ} 7, d a$ Lei 12-A/2008, e no art. 23. " da Lei 59/2008.", acaba por concluir que "No entanto, vindo o A exercitar, por via desta acção, direitos que em grande parte se reportam a período anterior a 01.01.2009, nomeadamente a qualificação do contrato que vigorou até esta data, bem como o pagamento de férias, subsídios de férias e de Natal vencidos até àquela data, a jurisdição laboral é a competente para conhecer dos mesmos, por estar em causa uma relação de trabalho que ainda não se tinha convertido numa relação de natureza administrativa." Quanto ao período posterior em que o contrato individual de trabalho já se teria convolado num contrato de trabalho em funções públicas mantêm a competência nos atuais juízos de trabalho "não pode deixar de estender-se a competência do Tribunal do Trabalho, nos termos do art. 85. ${ }^{o}$, alínea 
o), da LOFTJ, ${ }^{21}$ pois a estes compete conhecer «das questões entre sujeitos de uma relação jurídica de trabalho ou entre um desses sujeitos e terceiros, quando emergentes de relações conexas com a relação de trabalho, por acessoriedade, complementaridade e dependência, e o pedido se cumule com outro para o qual o tribunal seja directamente competente»".

Não obstante, o Tribunal de Conflitos no Acórdão n. ${ }^{\circ}$ 07/17, de 7 de dezembro de 2017, já acaba por afirmar taxativamente que também "Compete ao juízo do trabalho respetivo conhecer de contrato de trabalho, em funções públicas, no qual se converteu, por força do artigo $17^{\circ} 2$ da Lei $n^{o} 59 / 2008$, de 11-09, o contrato individual de trabalho celebrado entre o autor e o réu, entidade empregadora, Instituto Nacional de Estatística, instituto público.”, isto porque, ainda que o contrato seja, à data da propositura da ação (2015) um contrato de trabalho em funções públicas, “o autor fundamenta a ação tendo por base, em grande parte, numa relação laboral de direito privado, a competência para o julgamento do litígio, deve ser atribuída à jurisdição comum".

\section{c) Acidentes de Trabalho}

No caso do Acórdão do Tribunal de Conflitos de 18 de junho de 2014, proc. $\mathrm{n}^{\mathrm{o}}$ 050/13, ${ }^{22}$ a Autora foi admitida, através de um contrato de provimento, ao serviço na Caixa Geral de Depósitos. Nesse local sofreu um acidente de trabalho, de onde lhe advieram lesões. O Tribunal de Trabalho pronunciou-se no sentido de que não importa que a autora "esteja abrangida, na sua relação laboral, por um regime misto ou específico. Fundamental é que a Sinistrada celebrou, como a própria admite, um contrato de provimento, sendo beneficiária da Caixa Geral de Aposentações, com os inerentes direitos do regime da Função Pública, segundo o qual o regime jurídico dos acidentes de trabalho correm pelos Serviços Administrativos competentes, no caso a Caixa Geral de Aposentações ". Já o TAF do Porto considerou que, uma vez que a natureza jurídica da Caixa Geral de Depósitos tinha sido alterada pelo legislador no Decreto-Lei $n^{\circ}$ 287/93, de 20 de agosto, transformando-a numa empresa pública, aplicar-se-ia o regime do número 4 do artigo $2^{\circ}$ do Decreto-Lei $n^{\circ} 503 / 99$, de 20 de novembro e consequentemente seria o Código de Trabalho o regime aplicável. Na verdade, o Decreto-Lei n. ${ }^{\text {o } 503 / 99}$, de 20 de novembro é aplicável a "a todos os trabalhadores que exercem funções públicas, nas modalidades de nomeação ou de contrato de trabalho em funções públicas, nos serviços da administração direta e indireta do Estado" (n. $\left.{ }^{\circ} 1\right)$, mas não é aplicável "Aos trabalhadores que exerçam funções em entidades públicas empresariais ou noutras entidades não abrangidas pelo disposto nos números anteriores é aplicável o regime de acidentes de 
trabalho previsto no Código do Trabalho" (n. ${ }^{\circ}$ ). Por esse mesmo motivo o TAF do Porto considerou que deveriam ser os juízos de trabalho a decidir a questão, uma vez que a trabalhadora em causa tinha sofrido um acidente de trabalho na CGD, uma empresa pública. A esta tese aderiu o Tribunal de Conflitos.

É curioso, no entanto, que uns meses antes, a 06 de fevereiro de 2014, o Tribunal de Conflitos tenha proferido outro acórdão (processo $\mathrm{n}^{\circ}$ 024/12), em que considera que no caso de uma entidade pública empresarial (doravante EPE) é competente a jurisdição administrativa para julgar uma ação interposta por um dos trabalhadores dessa entidade em virtude da incapacidade que sofreu num acidente de trabalho. A Autora, à data do acidente, exercia funções de assistente operacional no Centro Hospitalar de Lisboa Ocidental, EPE. Nessa data também era o Decreto-Lei no 503/99 de 20 de novembro o regime que regulava os acidentes de trabalho ocorridos ao serviço das entidades empregadoras públicas. Contudo, neste caso o tribunal considerou que a EPE integrava a administração indireta do Estado e por isso estava sujeita à disciplina dos números 1,2 e 3 do Decreto-Lei referido. Estando sujeita a esse regime, os tribunais mais aptos a decidir a causa seriam os TAF. Em janeiro de 2018, o Tribunal de Conflitos (processo n. ${ }^{\circ}$ 053/17) num caso semelhante aos acima identificados, considerou que os tribunais competentes para apreciar de um acidente de trabalho seriam os tribunais comuns, uma vez que o acidente tinha sido sofrido por um trabalhador a exercer funções para um município, mas no âmbito de um contrato "emprego-inserção" promovido pelo IEFP e o trabalhador em causa não tinha "um vínculo para o exercício de funções públicas nas modalidades de nomeação ou de contrato de trabalho em funções públicas, o acidente em causa não pode ser considerado como acidente em serviço". Sucede que ao abrigo do Decreto-Lei n. ${ }^{\circ}$ 143/2012, de 11 de julho, o IEFP, I. P., “é um instituto público de regime especial, nos termos da lei, integrado na administração indireta do Estado, dotado de autonomia administrativa, financeira e património próprio." - cf. número 1 do artigo 1. ${ }^{\circ}$ do Decreto-Lei referido. Pelo que, enquanto no caso anterior, o Tribunal de Conflitos considerou competentes os TAF por o acidente ter sucedido numa EPE que integrava a administração indireta do Estado; neste caso, e apesar do IEFP integrar tambéma administração indireta do Estado, curiosamente foram considerados competentes os juízos de trabalho. 


\section{Comentário à jurisprudência analisada}

Feito este retrato analítico facilmente se compreende que não é tarefa fácil conjugar, por um lado o artigo $12^{\circ}$ da LGTFP, a alínea b) do número 4 do artigo $4^{\circ}$ do ETAF e, por outro lado, o artigo $126^{\circ}$ da Lei de Organização do Sistema Judiciário (“LOSJ”). $\quad$ Na verdade, apesar de muitas vezes o vínculo de constituição de emprego ter uma natureza pública, as matérias tratadas estão sujeitas a um regime em todo semelhante, senão exatamente igual ao previsto no CT. Nestes casos, deve de facto questionar-se se os TAF terão a mesma sensibilidade para dirimir este tipo de litígios. Aliás, deve sobretudo refletir-se sobre estas matérias quando nos deparamos, em zonas de fronteira, com decisões jurisprudenciais proferidas em sentidos opostos. Os casos retratados no subcapítulo supra são exemplo disso.

Assim devemos, em primeiro lugar, questionar até que ponto o critério da configuração pelo Autor da relação jurídico-material e do pedido delimita, efetivamente, a jurisdição por que se devem julgar estes litígios (ponto a)).

$\mathrm{Na}$ verdade, este critério parece nem sempre ser respeitado, o que origina muitas vezes os conflitos de jurisdição que aqui, brevemente, descrevemos.

Assim, se por um lado os TAF acabam, muitas vezes, por atender à configuração jurídicomaterial que os Autores colocam nos seus requerimentos e petições iniciais; os juízos de trabalho, sem norma habilitante para julgar litígios provenientes de vínculos de emprego público, não relevam a forma como a pretensão é configurada pelos Autores e, consideram-se, também incompetentes.

Sucede que o critério de definir a jurisdição competente apenas pelo modo como o Autor configura o seu pedido e descreve a relação jurídico-material controvertida, pode não ser suficiente ou, melhor dizendo, pode dar origem a situações que colocam em xeque o princípio da igualdade.

Na verdade, sabendo isto de antemão, pode o Autor configurar essa relação jurídica ao abrigo do direito laboral privado e por isso serem os juízos de trabalho a dirimirem o litígio que traz à demanda; ou ao abrigo de um vínculo de emprego público e a sua pretensão ser dirimida pelos TAF. Ora, parece claro que a competência para determinar efetivamente quem dirime este tipo de litígios não pode ser assim tão volátil (sob pena de estarmos perante situações semelhantes, a serem dirimidas em jurisdições diferentes, apenas porque foram apresentadas pelos Autores, de formas diferente). 
Para além disso, importa ainda notar que, ao abrigo do antigo artigo 83. ${ }^{\circ}$ da LVCR, os TAF eram competentes para dirimir litígios emergentes das "relações jurídicas de emprego público" - e daí, por exemplo, no primeiro acórdão analisado se terem considerado os mesmos competentes, ainda que o contrato em si fosse um contrato de provimento. Sucede que, atualmente, o artigo 12..$^{\circ}$ da LGTFP diz-nos que os TAF são competentes para dirimir litígios emergentes "do vínculo de emprego público".

Questionamo-nos se as expressões "vínculo de emprego público" e "relações jurídicas de emprego público" quererão dizer exatamente o mesmo ou se, pelo contrário, a segunda acaba por abranger mais situações - regidas, efetivamente, pelo direito público; mas não correspondentes aos vínculos de emprego público (a saber contrato de trabalho em funções públicas, nomeação e comissão de serviço). Seja por isso (ou não), a verdade é que desde a entrada em vigor da LGTFP, as decisões proferidas pelo Tribunal de Conflitos a considerar os TAF competentes para dirimir os litígios em questão são raríssimas (para não dizer inexistentes). Na verdade, a maior parte sustenta-se na forma como a relação jurídica é construída pelos Autores na petição inicial e não constando dela qualquer vínculo de emprego público, mas tão-só questões privado-laborais, o Tribunal de Conflitos tem acabado por considerar competentes os juízos de trabalho. Vejamos o recente Acórdão do Tribunal de Conflitos n. ${ }^{\circ}$ 065/17, de 17 de maio de 2018, que diz expressamente "Compete aos tribunais judiciais conhecer da acção em que se pede a declaração de ilicitude do alegado despedimento e a reintegração da Autora ao serviço de uma Freguesia quando o que se alegou não caracteriza um "contrato individual de trabalho da Administração Pública" ou um "contrato de trabalho em funções públicas”, mas simplesmente e por defeito, um contrato individual de trabalho". Ou ainda o Acórdão do Tribunal de Conflitos n. ${ }^{\circ}$ 047/17, de 25 de janeiro de 2018, "Compete à jurisdição comum conhecer da acção em que a autora, invocando um direito emergente de um alegado contrato de trabalho a termo, visa fundamentalmente obter a condenação do outro contraente no pagamento de «créditos laborais» subsequentes ao seu «despedimento» ilícito."

Por este prisma, parece-nos que, em termos práticos, poderemos efetivamente já estar a assistir a um esvaziamento do foro administrativo no que concerne às competências para dirimir litígios de emprego público (ou porque os mesmos ultrapassam os vínculos de emprego público que analisamos; ou porque, prevalecendo o critério da relevância da construção da demanda e do pedido pelo Autor, os litígios serão, em grande parte dos casos, forçosamente considerados laborais - até porque se a LGTFP remete, em grande parte das matérias para o CT, os Autores, 
nas suas petições iniciais invocarão não as normas da LGTFP, mas sim as normas do CT).

Podem ainda surgir casos como os que vimos, no ponto b) do capítulo anterior, em que o Autor, na prática, configura os dois modos de relação - jurídico-privada e, a partir de um certo momento, jurídico-pública, e definirem-se critérios como os que vimos - porque o pedido do Autor incide mais sobre um período temporal em que o que estava subjacente era um contrato individual de trabalho, então devem os juízos de trabalho julgar o litígio em questão; e julgar não só esse pedido, como os pedidos feitos já na decorrência da existência e reconhecimento (por parte do próprio Autor) de um vinculo de emprego público.

Significa isto que se o Autor configurasse a ação, e nela abarcasse um lapso temporal maior sujeito a um vínculo de emprego público, seriam já os TAF os tribunais competentes para dirimir este litígio? E seriam também os TAF competentes para dirimir o período temporal em que as partes estavam vinculadas por um contrato individual de trabalho, sujeito ao direito privado? É que a norma prevista na alínea n) do $n .^{\circ} 1$ do artigo $126 .^{\circ}$ da LOSJ e que dá competência aos juízos de trabalho para dirimir "Das questões entre sujeitos de uma relação jurídica de trabalho ou entre um desses sujeitos e terceiros, quando emergentes de relações conexas com a relação de trabalho, por acessoriedade, complementaridade ou dependência, e o pedido se cumule com outro para o qual o juízo seja diretamente competente", não está igualmente prevista para os TAF. Pelo contrário, diz-se na alínea b), do número 4 do artigo 4 . $^{\circ}$, que: "Estão igualmente excluídas do âmbito da jurisdição administrativa e fiscal: A apreciação de litígios decorrentes de contratos de trabalho, ainda que uma das partes seja uma pessoa coletiva de direito público”. Pelo que vimos no Acórdão do Tribunal de Conflitos n. ${ }^{\circ}$ 07/17, de 7 de dezembro de 2017, a resposta parece ser negativa. Na verdade, neste caso a Autora reclama créditos desde 2003 até 2015, tendo em vigor, entre 2003 e 2008, um contrato individual de trabalho que depois se transformou num contrato de trabalho em funções públicas - entre 2009 a 2015. Ora, mesmo vigorando por mais tempo a modalidade de contrato de trabalho em funções públicas (7 anos, em vez de 5), os juízos de trabalho foram considerados competentes para dirimir a ação. E mesmo tendo a ação sido proposta em 2015, em plena vigência da LGTFP.

Portanto, a questão não parece tão simples de resolver nem de delimitar, basta ver a diferença de posição do STA e do Tribunal de Conflitos que, futuramente, poderá gerar ainda mais conflitos de jurisdição.

Nos casos descritos no ponto c) do capítulo anterior, perante entidades claramente pertencentes ao setor empresarial do Estado, o Tribunal de Conflitos, em junho de 2014, considerou que os 
juízos de trabalho seriam os competentes para dirimir um caso de acidente de trabalho, apesar de em fevereiro do mesmo ano, ter considerado que a jurisdição competente era a administrativa. Tudo mudou com a interpretação que se fez acerca da natureza do empregador público: num caso considerou-se uma EPE como não fazendo parte da administração indireta e por isso sujeita ao regime do número 4 do $\operatorname{artigo} 2^{\circ}$ do referido Decreto-Lei; no outro caso já se considerou que fazia parte e por isso aplicou-se-lhe o regime previsto nos números 1,2 e 3 do artigo $2^{\circ}$ do Decreto-Lei $n^{\circ}$ 503/99, de 20 de novembro. E ainda mais insólito, no terceiro caso descrito, apesar do contrato ter sido celebrado com o IEFP, que integra a administração indireta do Estado, aqui os TAF já não seriam competentes, mas sim os juízos de trabalho. Porquê, pergunta-se, naturalmente. Mas carecem as respostas justificativas:mesmo perante entidades que integram o mesmo setor do Estado, há decisões diferentes por parte do Tribunal de Conflitos.

Ainda assim, independentemente das classificações que possam ser feitas acerca da natureza jurídica destas entidades, ${ }^{23}$ o que mais choca é saber que as situações em termos factuais são idênticas e que, apesar disso, um litígio pode acabar por ser atribuído aos TAF e outro aos juízos de trabalho.

É que o facto de se optar pela jurisdição comum num caso e noutro pela jurisdição administrativa comporta diferenças importantíssimas. E a consequência de um litígio ser dirimido por jurisdições diferentes pode chegar ao ponto de duas situações em tudo iguais terem um desfecho diferente, pondo-se desta forma em causa a segurança jurídica no nosso Estado de Direito. Na verdade, e como se afirma no Acórdão do Tribunal Central Administrativo do Sul, de 11 de abril de 2013, proc. no 07708/11, "é verdade que os tribunais administrativos e a legislação laboral pública é bem menos "flexível" do que a legislação laboral "privada" aplicada nos tribunais judiciais do trabalho". Aqui diz-se ainda que na "resolução dos conflitos laborais através dos Tribunais Administrativos não podem ocorrer acordos[extrajudiciais, não pode haver recurso à equidade, nem ao abrigo da alínea d) do número 1 do artigo $1800^{\circ}$ do CPTA recorrer-se à arbitragem quando estejam em causa direitos indisponíveis ou acidentes de trabalho], ao contrário do que se passa nos tribunais judiciais do trabalho”. Será que o facto da legislação laboral pública e administrativa ser mais rígida não cria situações de desigualdade face às questões julgadas nos juízos de trabalho (que são muitas vezes idênticas às questões que surgem nos TAF)? No acórdão em causa admite-se que "Quanto ao princípio da igualdade em sede de equiparação inovadora ao sector privado e em sede de tutela jurisdicional laboral como dantes, considera-se que, salvaguardando um núcleo 
material do que seja ser "servidor público", o vínculo laboral pode ser mais ou menos semelhante ao do trabalhador do sector privado. Tal núcleo não se nos mostra afetado”. No entanto, acaba por se concluir que a diferença de regimes (mais ou menos flexíveis) constitui "uma diferença justificada por haver aqui uma relação jurídica administrativa e ainda pelo tal núcleo material do servidor público plasmado nos artigos $266^{\circ}, 269 .^{\circ}, 271^{\circ}$ da CRP. Para situações distintas, remédios tutelares distintos".

Acontece que, nos casos aqui citados, as situações não pareciam de todos distintas, mas sim extremamente semelhantes. E sabemos que o princípio da igualdade se baseia na premissa de que devemos tratar o igual como igual e o desigual como desigual. Ele também se aplica na questão do acesso aos tribunais. Aliás, como nos diz Gomes Canotilho e Vital Moreira (2014, p. 346) "a vinculação da jurisdição pelo princípio da igualdade comporta três dimensões fundamentais: (a) igualdade de acesso dos cidadãos à jurisdição (art. 20-1); (b) igualdade dos cidadãos perante os tribunais; (c) igualdade de aplicação do direito aos cidadãos através dos tribunais (...) Finalmente a igualdade de aplicação do direito relaciona-se estreitamente com a vinculação jurídico-material do juiz ao princípio da igualdade. As manifestações mais relevantes são a aplicação de igual direito a casos idênticos (...)”. Ora, nos casos retratados parece haver dúvidas que o princípio da igualdade tenha sido respeitado, por se ter aplicado a duas situações concretamente idênticas uma jurisdição distinta.

Por fim, importa ainda equacionar, por que razão serão os TAF os tribunais (mais) competentes para dirimir questões referentes, por exemplo, às retribuições por desempenho de trabalho suplementar ${ }^{24}$ ou aos regimes de tempo de trabalho, ${ }^{25}$ quando estas matérias são constantemente trabalhadas pelos tribunais de trabalho e se regem, mesmo no emprego público, pelas disposições do CT? Mais, estas diferenças não colocarão em causa o acesso efetivo ao direito? De facto, não podemos esquecermo-nos que a efetividade no acesso ao direito exige sentenças adequadas às pretensões de tutela deduzidas em juízo, tribunais e recursos humanos especializados para estas matérias. E não parece que os tribunais administrativos estejam mais vocacionados para decidir nestes casos.

\section{Conclusões}

Resta-nos concluir e ponderar a adequação do artigo $12^{\circ}$ da LGTFP e da alínea b) do número 4 do $4 .^{\circ}$ do ETAF, atendendo ao quadro legislativo e jurisprudencial nacionais. Mais do que 
ponderar as diferentes posições doutrinais existentes nestas matérias, importa constatar aquilo que se tem verificado na prática jurisprudencial. Na verdade, pelo que aqui foi explanado, a redação atual do artigo $12^{\circ}$ da LGTFP cria inúmeros problemas para os tribunais. Têm frequentemente surgido conflitos de jurisdição, e a maior parte das vezes, negativos, o que significa que nem os tribunais administrativos nem os juízos de trabalho se consideram competentes para dirimir sobre matérias público-laborais. Claramente há um desconforto patente nos TAF quando confrontados com questões que, apesar de poderem ter como background um vínculo de emprego público, são, na prática, típicas das relações privadas laborais. Por outro lado, os tribunais comuns, sempre que se encontram perante uma relação jurídica nascida no seio do direito público afastam, de imediato, a sua competência, por não haver norma legal que os habilite a dirimir tais litígios.

Por sua vez, o Tribunal de Conflitos atribuicada vez maisa competência para dirimir os litígios emergentes de relações de emprego públicoaos juízos de trabalho fazendo-nos, parece, uma interpretação restritiva do artigo 12. ${ }^{\circ}$ da LGTFP e do artigo 4.\%/4/b) do ETAF. Há, claramente, um esvaziamento das competências dos TAF nestas matérias, que não pode ser ignorada.

Urge então resolver este problema. A penúltima redação do anteprojeto da LGTFP aproximouse de uma solução que poderia ter diminuído consideravelmente os conflitos negativos de jurisdição. Na verdade, considerava, regra geral, os tribunais de trabalho competentes para dirimir os litígios emergentes do vínculo de emprego público, exceto nos casos em que fosse necessária a verificação da invalidade do ato administrativo que fundou a constituição ou modificação do vínculo de emprego público. Esta solução parecia ser razoável, uma vez que aos tribunais de trabalho eram entregues as matérias reguladas pelo CT e aos tribunais administrativos cabiam as questões da invalidade dos atos administrativos, matéria que, por natureza, já lhes é inerente. ${ }^{26}$

Claro está que, nos juízos de trabalho, poderia efetivamente surgir algum desconforto com esta solução. Consideramos que, esse desconforto, a surgir, seria essencialmente na modalidade de constituição do vínculo de emprego público formadas por um ato unilateral da Administração Pública: a nomeação ou a comissão de serviço. Em relação ao contrato de trabalho em funções públicas, atendendo à semelhança que assume para com o típico contrato de trabalho privado, ${ }^{27}$ não cremos existirem razões para esse desconforto se verificar. ${ }^{28}$ Pelo que, a admitir-se alguma alteração a redação do anteprojeto, seria no sentido de manter a atribuição de competência aos tribunais de trabalho para dirimirem sobre contrato de trabalho em funções públicas e restringi- 
la nas modalidades de nomeação e comissão de serviço. Assim, aos TAF caberia tudo aquilo que possivelmente estivesse relacionado com o ato unilateral emitido pela AP (e não apenas a sua invalidade, mas também procedimento administrativo de constituição, alteração e execução). Tudo o que, ainda que perante um ato unilateral, se reportasse materialmente a matéria laboral, caberia na mesma aos juízos de trabalho. ${ }^{29}$

Somos da opinião proferida por Palma Ramalho de que deverá ter-se em conta a similitude das situações (independentemente do vínculo que lhes deu origem) e que os juízos de trabalho se encontram, tecnicamente, mais preparados para dirimir este tipo de litígios. Optando por esta solução deixaria de existir qualquer conflito para com as normas do ETAF e reduzir-se-iam, e muito, os conflitos negativos de jurisdição, tal como ficou aqui claro. No fundo, assumir-se-ia aquilo que nos parece que já acontece na prática - o esvaziamento do foro administrativo nestas matérias. A manutenção de uma solução que não corresponde à realidade jurisprudencial não pode sobreviver por se considerar que os TAF são mais céleres que os juízos de trabalho (o queatendendo, mais uma vez, à prática quotidiananão parece de todo corresponder à verdade) ou por se considerar que os juízos de trabalho são "menos parciais". Do artigo 269. da CRP não parece constar qualquer impedimento a esta solução, prevalecendo, sem dúvida aqui, o princípio da igualdade, previsto no artigo $13 .^{\circ}$. Na verdade, a especialidade do regime da função pública prevista no artigo $269 .^{\circ}$ da CRP não é colocada em causa quando o conteúdo material das relações é similar, no sentido de ser privado-laboral e regido por normas do CT. Aliás é a própria LGTFP a reconhecer, em muitas matérias, que os direitos e obrigações dos trabalhadores com vínculo de emprego público (e até mesmo o interesse público) ficam (bem) assegurados pelo direito laboral privado, remetendo para o mesmo.

Enfim, resta concluir que, adotando uma solução dentro dos moldes da aqui explicada, e que podia bem ser a plasmada na redação prevista até ao último anteprojeto da LGTFP, haveria certamente uma redução dos conflitos de jurisdição que até então temos assistido, bem como o risco de serem desrespeitados princípios fundamentais do nosso ordenamento jurídico, quer seja o do acesso aos tribunais (com recurso a justiça efetiva e de qualidade) quer o do princípio da igualdade.

Por fim, resta acrescentar que o anteprojeto do novo ETAF prevê a criação, no artigo 44. ${ }^{\circ}$-A, de juízos administrativos especializados, nomeadamente, na alínea b), a criação de um “ juízo administrativo social" a quem compete "conhecer de todos os processos relativos a litígios em matéria de emprego público e da sua formação, ou relacionados com formas públicas ou privadas de proteção social, exceto os relativos ao pagamento de créditos laborais por parte 
do Fundo de Garantia Salarial”. Se esta solução se concretizar, acreditamos que poderá diminuir as nossas reservas da competência para litígios emergentes de vínculo de emprego público estarem entregues aos TAF, sobretudo no que concerne à questão da técnica/especialização dos magistrados; mas isso, ainda assim, não resolve todos os outros problemas que apontamos de interpretação da lei e garantia do respeito pelos princípios constitucionais de igualdade e acesso (efetivo à justiça).

\section{Notas de rodapé}

1 Que tanto podem ser direitos, liberdades e garantias como direitos económicos, sociais e culturais.

2 Exemplo de um direito, liberdade e garantia presente no artigo $53^{\circ}$ da CRP

3 Exemplo de um direito económico, social e cultural constante do artigo $58^{\circ}$ da CRP.

4 Consagrado no artigo $20^{\circ}$ da CRP.

5 Para além do vínculo de emprego prevê-se na LGTFP, mais concretamente no número 1 do artigo $6^{\circ}$ e no artigo $32^{\circ}$, a possibilidade do trabalho em funções públicas poder ser prestado mediante um contrato de prestação de serviços, situação que já é alvo de críticas doutrinais, no sentido de se considerar que a LGTFP apenas deveria tratar das relações laborais onde existe subordinação jurídica.

6 Conforme consta expressamente do número 3 do artigo $6^{\circ}$ da LGTFP.

7 Lei n. ${ }^{\circ}$ 12-A/2008, de 27 de fevereiro. 
8 É o caso do recrutamento de trabalhadores, a cessação do vínculo do trabalho em funções públicas, a estruturação de carreiras, a mobilidade, a cedência do interesse público, o estatuto remuneratório, o exercício do poder disciplinar, os direitos, deveres e garantias de imparcialidade dos trabalhadores em funções públicas.

9 Como decorre do artigo $126^{\circ}$ da Lei $n^{\circ} 62 / 2013$, de 26 de agosto

$10 \mathrm{O}$ artigo $83 .^{\circ}$ da LVCR já afirmava que "Os tribunais da jurisdição administrativa e fiscal são os competentes para apreciar os litígios emergentes das relações jurídicas de emprego público."

11 A solução adotada no sistema italiano.

12 Posição formulada oralmente em sessão subordinada ao tema «Contrato a termo na Lei Geral do Trabalhoem Funções Públicas» integrada no âmbito da Conferência «Contrato de Trabalho a Termo: Flexibilidade vs Precariedade», organizada pelo Instituto de Direito do Trabalho e que decorreu na Faculdade de Direito da Universidade de Lisboa no dia 30 de Outubro de 2014.

13 Para aprofundar mais as posições doutrinais cf., ainda, Lourenço Vilhena de Freitas, $O$ contencioso sobre a execução do Contrato de Trabalho em Função Públicas no Anteprojecto da Lei Geral do Trabalho em Funçães Publicas, disponível em https://www.icjp.pt/sites/default/files/papers/contencioso_da_execucao_dos_contratos_no_anteprojecto_da_lei geral do trabalho em funcoes publicas.pdf

14 Alínea a) do número 1 do artigo $130^{\circ}$ da LOSJ "Preparar e julgar os processos relativos a causas não atribuidas a outra secção da instância central ou tribunal de competência territorial alargada".

15 Artigo $64^{\circ}$ do CPC "São da competência dos tribunais judiciais as causas que não sejam atribuídas a outra ordem jurisdicional".

16 Cf. número 3 do artigo 212. ${ }^{\circ}$ da Constituição da República Portuguesa.

17 Todos os acórdãos referidos ao longo deste artigo estão disponíveis em www.dgsi.pt.

18 Esta posição é aceite pelos tribunais. Veja-se por exemplo, o Acórdão do Supremo Tribunal Administrativo de 11 de julho de 2000 , recurso ${ }^{\circ} 318$.

19 Exigido na altura de acordo com o número 4 do artigo $59^{\circ}$ do Decreto-Lei no 167/84, de 22 de maio.

20 E o mesmo se tem vindo a dizer no próprio Supremo Tribunal de Justiça (Proc. n. ${ }^{\circ}$ 492/09.2TTPRT.P1.S1, de 30/03/2011; Proc. n. ${ }^{\circ}$ 204/11.0TTVRL.P1.S1, de 12/09/2013; Proc. 2596/11.2TTLSB.L1.S1, de 18/06/2014.)

21 Atual alínea n) do número 1 do artigo 126.․a LOSJ.

22 Aqui, mais uma vez, estávamos perante um conflito negativo de jurisdição.

23 E sabemos que a Caixa Geral de Depósitos levanta algumas opiniões divergentes, sendo pacífico, no entanto que se encontra integrada no setor empresarial do estado (onde se incluem as empresas públicas e as entidades públicas empresariais).

24 P.ex. artigo $120^{\circ}$ da LGTFP

25 P.ex. artigo $126^{\circ}$ da LGTFP

26 Artigo $50^{\circ}$ do Código do Processo nos Tribunais Administrativos

27 Patente no capítulo 3 deste trabalho.

28 E fora dos vínculos de emprego público, certamente o contrato de prestação de serviços não seria também novidade para os tribunais de trabalho.

29 Claro está que, matérias como o recrutamento e procedimentos concursais teriam também que ser sempre entregues aos TAF. Mas aqui estamos a falar de uma fase anterior à constituição do vínculo de emprego público. 


\section{Referências bibliográficas}

\section{Legislação}

Código de Processo Civil

Código de Processo dos Tribunais Administrativos

Código do Trabalho

Constituição da República Portuguesa 


\section{pontěditora}

Decreto-Lei no 503/99, de 20 de novembro

Decreto-Lei nº 287/93, de 20 de agosto

Decreto-Lei n. ${ }^{\circ}$ 143/2012, de 11 de julho

Estatuto dos Tribunais Administrativos e Fiscais (e seu Anteprojeto)

Lei de Organização do Sistema Judiciário

Lei dos Vínculos, Carreiras e Remunerações

Lei Geral do Trabalho em Funções Públicas

Proposta de Lei n. ${ }^{\circ}$ 184/XII

\section{Obras}

Almeida, Luís Filipe Mota (2016). Notas breves sobre o Âmbito da Jurisdição Administrativa

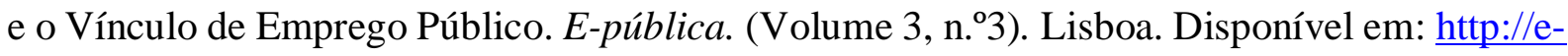
publica.pt/volumes/v3n3a13.html.

Andrade, Manuel De (1993). Noções Elementares de Processo Civil.Coimbra: Coimbra Editora.

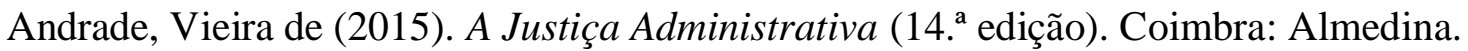

Brito, Pedro Madeira de (2010). Contrato de Trabalho da Administração Pública e sistema de fontes. Lisboa.

Canotilho, Gomes \& Moreira, Vital (2014). Constituição da República Anotada, Artigos $1^{o} a$ $107^{\circ}$ (Vol.I). Coimbra: Coimbra Editora,

Freitas, Lourenço Vilhena de. O contencioso sobre a execução do Contrato de Trabalho em Função Públicas no Anteprojecto da Lei Geral do Trabalho em Funções Publicas. Disponível em:

https://www.icjp.pt/sites/default/files/papers/contencioso_da_execucao_dos_contratos_no_ant eprojecto_da_lei_geral_do_trabalho_em_funcoes_publicas.pdf.

$\mathrm{J}^{2}$ - Jornal Jurídico | Volume 1 | Número 1 
Martins, David Carvalho \& Coelho, Susana Santos. (2017). A tutela dos direitos dos trabalhadores na Administração Pública nos Tribunais Administrativos e nos Tribunais de Trabalho em sede de acidentes de trabalho e doenças profissionais. Coleção Formação Contínua Direito do Trabalho na Administração Pública (Vol. I). Disponível em: http://www.cej.mj.pt/cej/recursos/ebooks/Administrativo_fiscal/eb_Direito_do_Trabalho_na_ Administracao_Publica_I.pdf.

Miranda, Jorge \& Medeiros, Rui (2007). Constituição da República Portuguesa, Tomo III. Coimbra: Coimbra Editora.

Neves, Ana Fernanda (2006). O Contrato de Trabalho na Administração Pública.Estudos em homenagem ao Professor Doutor Marcello Caetano no centenário do seu nascimento / ed. lit.(Vol. I.). Faculdade de Direito da Universidade de Lisboa. Coimbra: Coimbra Editora.

Nunes, Cláudia Sofia Henriques (2014). O Contrato de Trabalho em Funções Públicas face à lei geral do trabalho (1 $1^{\mathrm{a}}$ edição). Coimbra: Coimbra Editora.

Pires, Miguel Lucas (2016). Lei Geral do Trabalho em Funções Públicas, Anotada e Comentada.Almedina.

Silva, Vasco Pereira da (2016). O Contencioso Administrativo no Divã da Psicanálise - Ensaio sobre as Acções no Novo Processo Administrativo(Reimpressão da 2. a edição). Coimbra: Almedina.

\section{Jurisprudência (todos disponíveis em:www.dgsi.pt)}

Acórdão do Tribunal de Conflitos (03 de julho de 2003). Proc. n. ${ }^{\circ}$ 013/03.

Acórdão do Tribunal Administrativo Central Sul (08 de novembro de 2007). Proc. $\mathrm{n}^{\circ}$ 00392/04.

Acórdão do Tribunal de Conflitos (8 de novembro de 2011).Proc. n. ${ }^{\circ}$ 11/05.

Acórdão do Tribunal Central Administrativo do Sul (11 de abril de 2013). Proc. nº 07708/11.

Acórdão do Tribunal de Conflitos (20 de junho de 2013). Proc. n. ${ }^{\circ} 022711$,

Acórdão do Tribunal de Conflitos (16 de janeiro de 2014). Proc. n. ${ }^{\circ}$ 056/13.

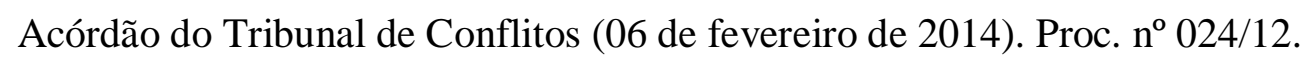


Acórdão do Tribunal de Conflitos (18 de junho de 2014). Proc. nº 050/13.

Acórdão do Supremo Tribunal Administrativo (16 de junho de 2015). Proc. 117/14.4TTLMG.C1.S1.

Acórdão do Tribunal de Conflitos (01 de outubro de 2015) Proc. n. ${ }^{\circ}$ 08/14.

Acórdão do Tribunal de Conflitos (17 de novembro de 2016)Proc. n. ${ }^{\circ}$ 017/16.

Acórdão do Tribunal de Conflitos (08 de março de 2017). Proc. n. ${ }^{\circ}$ 012/15.

Acórdão do Tribunal de Conflitos (07 de dezembro de 2017). Proc. n. o 07/17.

Acórdão do Tribunal de Conflitos (25 de janeiro de 2018). Proc. n. ${ }^{\circ}$ 053/17.

Acórdão do Tribunal de Conflitos (17 de maio de 2018). Proc. n. o 065/17. 


\section{Formula aequalitas na actividade administrativa}

\section{Formula aequalitas in administrative activity}

Ana Cristina Martins Roso ${ }^{1}$ Email: ana.roso@gmail.com Docente do Instituto Superior de Contabilidade e Administração de Coimbra

Doutorada em Direito Público e Mestre na área do Direito

Administrativo pela

Faculdade de Direito da Universidade de Coimbra
Resumo: Pretende-se analisar o princípio da igualdade na actividade administrativa, daí o título do nosso artigo: "Formula aequalitas na actividade administrativa". Começar por referir que o princípio da igualdade, que se encontra previsto no artigo $13 .^{\circ}$ da Constituição da República Portuguesa, é um dos princípios estruturantes do Estado de Direito Democrático e Social. Sendo também um dos princípios fundamentais materiais da actividade administrativa, nos termos do artigo 6. ${ }^{\circ}$ do novo Código do Procedimento Administrativo (corresponde ao artigo 5..$^{\circ}$ do antigo Código do Procedimento Administrativo). Propomonos, depois de analisar a sua importância e consagração na Lei Fundamental, irmos verificar da importância que vem assumindo o princípio da igualdade no seio da actividade administrativa.

Palavra-chave: Princípio da igualdade. Princípio de Estado de Direito Democrático e Social. Actividade administrativa. Princípio fundamental da actividade administrativa.

Abstract: It is intended to analyze the principle of equality in
administrative activity, hence the title of our article: "Formula aequalitas
in administrative activity". It should be noted that the principle of equality,
which is laid down in Article 13 of the Constitution of the Portuguese
Republic, is one of the structuring principles of the rule of democratic and
social law. It is also one of the basic material principles of administrative
activity, in accordance with Article 6 of the new Code of Administrative
Procedure (corresponds to Article 5 of the former Code of Administrative
Procedure). We propose, after analyzing its importance and consecration
in the Basic Law, to verify the importance of the principle of equality in
administrative activity.

Keyword: Principle of equality. Principle of State of Democratic and Social Law. Administrative activity. Basic principle of administrative activity. 


\section{Introdução}

Este ensaio corresponde a uma adaptação e actualização de uma investigação realizada no âmbito da cadeira de Jurisprudência de Direito Administrativo, do 2. ${ }^{\circ}$ Ciclo de Estudos da Faculdade de Direito da Universidade de Coimbra, no passado ano lectivo de 2007/2008. Este trabalho centra-se no princípio da igualdade, que é um dos princípios fundamentais materiais da actividade administrativa.

O princípio da igualdade é um dos princípios estruturantes do Estado de Direito Democrático e Social. Marcando presença em textos constitucionais desde há dois séculos, este princípio esteve exposto a uma grande evolução ao longo deste tempo. É um princípio teoricamente complexo e de aplicação prática extremamente difícil. No entanto, é portador de um significado, rico, fascinante e simbólico, falar de igualdade é falar da própria dignidade humana e do próprio princípio de justiça, (o símbolo do Direito é uma pessoa do sexo feminino de olhos vendados, com uma balança numa das mãos e na outra uma espada, a balança pretende significar igualdade).

Propomo-nos fazer uma breve explanação pela consagração constitucional do princípio da igualdade, para em seguida passar a uma análise doutrinal e legal da consagração do mesmo no (novo) Código de Procedimento Administrativo. De notar que quando foi feita a investigação inicial (durante o nosso mestrado) que levaria à redacção do presente artigo (ano lectivo 20072008) vigorava o anterior Código do Procedimento Administrativo, que havia sido aprovado pelo Decreto-Lei n. ${ }^{\circ}$ 442/91, de 15 de novembro, o qual sofreu várias alterações, até ser revogado pelo Decreto-Lei n. ${ }^{\circ}$ 4/2015, de 07 de Janeiro, que aprovou o novo Código do

Procedimento Administrativo (doravante CPA), daí a necessidade de agora proceder à actualização do presente artigo (conforme referido supra).

\section{O Princípio da igualdade e o constitucionalismo}

Falar no princípio da igualdade é, antes de mais, falar em princípios jurídicos, mas o que se entende por princípio?

O Princípio "traduz um sentido do direito, um vector que informa o conteúdo das normas, orientando o legislador e o intérprete, mas que pode, em determinadas condições ser directamente aplicada a casos concretos. Induz-se de fontes e normas pela construção e 
sistematização científica" ${ }^{\text {. }}$

Avancemos, então agora, com uma noção de princípio da igualdade (jurídica), “o seu sentido primário ou negativo consiste na proibição de privilégios e de discriminações (...) Destinatários do princípio vêm a ser, desde logo, os órgãos de criação. Igualdade significa hoje, antes de mais, criação de lei igual para todos. Mas este princípio significa, talvez, ainda mais aplicação igual da lei, os seus destinatários são tanto os tribunais como os órgãos e agentes administrativos"6.

O princípio da igualdade é um dos princípios estruturantes do sistema constitucional global, harmonizando no seu conteúdo as dimensões liberais, democráticas e sociais, dimensões que são inerentes ao próprio conceito de Estado de Direito democrático e social (artigo $2 .^{\circ}$ da Constituição da Republica Portuguesa, CRP).

Mas este princípio tal como hoje o conhecemos, é o produto de uma longa evolução.

A igualdade assim como a liberdade adquiriram com as Revoluções Liberais, um sentido fundamentante e estruturante da vida político-social. A vontade de garantir a sua concretização era tão grande nesta época, que fez emergir vários documentos formais de natureza especiais: as Declarações de Direitos e, em particular, as Constituições escritas. A igualdade dos homens foi, pela primeira vez, consagrada juridicamente, na América, na Virginia Bill of Rights, em 12 de Junho de 1776, onde se reconheceu que "todos os homens são por natureza igualmente livres e independentes e têm certos direitos inerentes", tendo sido retomada, também na América, na Constituição de Massachussets, de 2 de Março de 1780, onde se consagrou que, "todos os homens nasceram livres e iguais, e têm certos direitos naturais, essenciais e inalienáveis", depois em França numa formulação mais clara, na 1. " Declaração dos Direitos do Homem e do Cidadão", em 1789, onde se prevê que, "os homens nascem e são livres e iguais em direitos"7.

Estes textos prepararam o hoje "clássico" enunciado do princípio da igualdade perante a lei,

\footnotetext{
${ }^{5}$ João Melo Franco e António Herlander Antunes Martins, “Dicionário de Conceitos e Princípios Jurídicos: na Doutrina e na Jurisprudência”, 3. ' Edição, Almedina, 1993, pág. 689.

6 Idem, pág. 693.

7 Como vimos, foi na América que pela primeira os textos básicos consagraram pela primeira vez constitucionalmente a igualdade. Assim, não coube à França (como muitos ainda hoje erroneamente pensam) esta glória. Coube-lhe, apenas, sim o enunciado que, por ser o mais conhecido, se tornou o mais influente. Vide Martim de Albuquerque, “Da Igualdade - Introdução à Jurisprudência”, Livraria Almedina, Coimbra, 2003, pág. 45 47.
} 
consagrada na Declaração dos Direitos do Homem e do Cidadão, de França em 1793, "[t]odos os homens são iguais por natureza e diante da lei”. A partir de então, este princípio foi adquirido como um verdadeiro axioma jurídico de todas as Constituições, até aos nossos dias. Também, as Constituições Portuguesas, do século XIX (Constituição de 1822, Carta Constitucional de 1826 e Constituição de 1838), influenciadas pela ideologia saída das Revoluções Americana e Francesa, já consagravam o princípio da igualdade ${ }^{8}$.

Muitos foram os textos constitucionais e as Declarações de Direitos que se seguiram ao supra exposto, mas devido à sua importância não podemos deixar de referenciar aqui o $\operatorname{artigo~} 1^{\circ}$, da Declaração Universal dos Direitos do Homem, adoptada e proclamada pela resolução 217 A (III) da Assembleia Geral das Nações Unidas em 10 de Dezembro de 1948, cujas palavras, nunca são de mais relembrar: "Todos os seres humanos nascem livres e iguais em dignidade e direitos. Dotados de razão e de consciência, devem agir uns para com os outros em espírito de fraternidade" 9 .

\subsection{O princípio da igualdade e o artigo $13 .^{\circ}$ da CRP}

A Constituição Portuguesa de 1976 consagra o princípio da igualdade no seu artigo 13. ${ }^{\circ}$, onde podemos ler no n. ${ }^{\circ} 1$, “[t] odos os cidadãos têm a mesma dignidade social e são iguais perante a lei”, e no n. 2 , “[n]inguém pode ser privilegiado, beneficiado, prejudicado, privado de qualquer direito ou isento de qualquer dever em razão da ascendência, sexo, raça, língua, território de origem, religião, convicções politicas ou ideológicas, instrução, situação económica, condição social ou orientação sexual".

Este princípio será, eventualmente, o mais antigo com consagração constitucional, essa longevidade constitucional fê-lo experimentar, como já referimos, uma evolução acentuada e multifacetada. Como ele é actualmente entendido na generalidade dos Estados democráticos, consegue conciliar dialecticamente diferentes dimensões. No entanto, continua a abrir-se a novas e discutíveis utilizações que o tornam num princípio sempre aberto, controverso e de compreensão não tão linear quanto uma evolução "refinada" ao longo dos tempos podia fazer

\footnotetext{
${ }^{8}$ Maria Glória F.P.D. Garcia, “Estudos sobre o Princípio da Igualdade”, Almedina, 2005, pág. 31.

${ }^{9}$ Idem, pág. 8 .
} 


\section{pontèditora}

esperar $^{10}$.

Este princípio é, pois, uma síntese dialéctica entre três diferentes dimensões: uma dimensão liberal, na qual o princípio da igualdade fornece a ideia de igualdade de todas as pessoas, independentemente do seu nascimento e do seu status, perante a lei, que é geral e abstracta, considerada subjectivamente universal em virtude da sua impessoalidade e da aplicação a um número indeterminável de casos. Uma dimensão democrática que exige uma proibição de discriminações, quer seja no acesso e participação no exercício do poder político e também no acesso a cargos públicos. Por último, uma dimensão social, na qual se salienta a função social do princípio da igualdade, impondo a eliminação das desigualdades fácticas (sociais, económicas e culturais), para que assim se possa alcançar a "igualdade real entre portugueses"11.

A base constitucional do princípio da igualdade é a igual dignidade social de todos os cidadãos (n. ${ }^{\circ} 1$ do artigo $13 .^{\circ}$ da CRP), que mais não é do que um corolário da igual dignidade de todas as pessoas.

$\mathrm{Na} 2 .^{\circ}$ parte, do ${ }^{\circ}{ }^{\circ} 1$, do artigo $13^{\circ}$, da CRP ao determinar-se $\boldsymbol{a}$ igualdade dos cidadãos perante a lei, acolhe-se a versão adquirida da fórmula clássica do princípio da igualdade com que se colocou fim às desigualdades de nascimento e de estatuto jurídico no "antigo regime". No fundo, este princípio trata da igualdade de todos em matéria de direitos e deveres, todos devem beneficiar de direitos e vantagens, e todos devem suportar deveres e encargos.

"A igualdade desdobra-se em duas proibições e uma obrigação - proibição de arbítrio, proibição de discriminação e obrigação de diferenciação" 12 .

A proibição do arbítrio, traduz-se num limite externo da liberdade de conformação ou de decisão dos poderes públicos, serve aqui este princípio como princípio negativo de controlo: nem aquilo que é essencialmente igual deve ser tratado arbitrariamente (sem fundamentação, ou com uma justificação insuficiente) como desigual, nem o fundamentalmente desigual deve ser de modo arbitrário tratado como igual. Assim, este princípio significa que positivamente é

\footnotetext{
${ }^{10}$ Jorge Reis Novais, “Os Princípios Constitucionais Estruturantes da República Portuguesa”, Coimbra Editora, 2004, pág.101.

${ }^{11}$ J.J. Gomes Canotilho e Vital Moreira, “Constituição da República Portuguesa Anotada”, Vol. I, 4. ${ }^{\text {E Edição }}$ Revista, 2007, anotação ao artigo ${ }^{\circ} 13$, pág. 337.

${ }^{12}$ Martim de Albuquerque, "Da Igualdade", cit., pág. 334-337, e Gomes Canotilho e Vital Moreira, "Constituição Anotada", Vol. I, cit., pág. 339-342.
} 
necessário um tratamento igual de situações efectivamente iguais e um tratamento desigual de situações efectivamente desiguais. Quanto à proibição de discriminação (n. ${ }^{\circ}$, do artigo $\left.13 .^{\circ}\right)$, não exige um tratamento totalmente igualitário em todas as situações, nem se proíbe as diferenciações de tratamento. O que se proíbe são os factores de discriminações ilegítimos, previstos na Constituição, (no já referenciado n. ${ }^{\circ} 2$, do artigo $13^{\circ}$ ).

Assim, as medidas de diferenciação serão legítimas desde que: se baseiem em casos objectivamente e justificadamente distintos, não se fundamentem em nenhuma das situações mencionadas no n. ${ }^{\circ}$, do artigo $13 .^{\circ}$, não contrariem a Constituição e se mostrem necessárias, adequadas e proporcionais à realização do objectivo que visam alcançar ${ }^{13}$. As decisões do Tribunal Constitucional (TC), continuam a assinalar correctamente, que o princípio da igualdade não impede a diferenciação de tratamento, mas apenas discriminações arbitrárias, irrazoáveis, sem justificação ou sem fundamentação material bastante ${ }^{14}$.

Por último, a obrigação de diferenciação, pretende compensar a desigualdade de oportunidades, aqui podemos ver claramente uma manifestação da função social deste princípio. Na realidade, não há violação do princípio da igualdade quando se verifica uma discriminação positiva (um benefício) a favor do mais débil, do mais frágil, do mais desprotegido, visto que está em consonância com o sistema jurídico-constitucional. Mais, no que respeita à função de protecção do princípio da igualdade, relativamente às discriminações positivas, ele constitui claramente uma imposição constitucional em nome da igualdade de oportunidade, por exemplo, n. ${ }^{\circ} 3$ do artigo $68^{\circ}$, n. $^{\circ} 2$ do artigo $69 .^{\circ}$ e n. ${ }^{\circ} 1$ do artigo $70 .^{\circ}$, (todos da CRP).

\subsection{O princípio da igualdade e o artigo $266^{\circ}$ da CRP}

Todas as funções estaduais estão vinculadas ao princípio material da igualdade. "O princípio da igualdade repercute-se nos actos legislativos, vedando o arbítrio do legislador, e nos actos administrativos e judiciais, em relação aos quais prescreve a unidade na aplicação do direito

\footnotetext{
13 Gomes Canotilho e Vital Moreira, "Constituição Anotada", Vol.I, cit., pág. 340.

${ }^{14}$ Vide, por exemplo Acórdão do TC n. ${ }^{\circ}$ 80/86, Proc. n. ${ }^{\circ}$ 148/84, publicado no D.R. n. ${ }^{\circ} 131$, de 09/06/86, I Série, págs. 1366 a 1373.
} 
feita pela Administração e pelos tribunais"15.

No que concerne, especificamente, à Administração Pública, prescreve o n. ${ }^{\circ} 2$ do artigo 266. ${ }^{\circ}$ da CRP, “[o]s órgãos e agentes administrativos estão subordinados à Constituição e à lei e devem actuar, no exercício das suas funções, com respeito pelos princípios da igualdade, da proporcionalidade, da justiça e da imparcialidade”. Pretende-se aqui salientar a vinculação administrativa às normas e aos princípios constitucionais, designadamente ao princípio da igualdade, incluindo a proibição do arbítrio e da discriminação. Assim, o princípio da igualdade (n. ${ }^{\circ} 2,2{ }^{\circ}$ parte) é nesta sede, um reflexo do princípio jurídico geral da igualdade consagrada no artigo $13 .^{\circ}$ Este princípio postula que se dê tratamento igual a situações de facto essencialmente iguais e tratamento diverso a situações de facto desiguais ${ }^{16}$.

\section{O princípio da igualdade na doutrina e no código do procedimento administrativo (CPA)}

\subsection{Evolução da compreensão do princípio da igualdade}

A compreensão do princípio da igualdade enunciado, como vimos, primeiramente, em França, na Declaração de Direitos do Homem e do Cidadão, de 1793, não foi sempre a mesma. O entendimento que se tem deste princípio passou por três fases essenciais ${ }^{17}$.

Numa primeira fase, o princípio da igualdade confunde-se com o princípio da prevalência da lei. Na época liberal, em que o Direito se resumia à lei (positivismo jurídico), o princípio da igualdade, surgia-nos como um valor absoluto, e sem reservas, o que o conduzia a um princípio meramente formal. Assim, nesta fase ser considerado igual perante uma lei, que era geral e abstracta, significa ser destinatário da aplicação dessa lei.

Esta ideia de igualdade formal, na prática levava a desigualdades, pelo que houve necessidade

\footnotetext{
${ }^{15}$ Maria Aline Gago da Silva e Jorge Baptista Bruxo, "Princípios Jurídicos da Administração Pública”, Imprensa Nacional - Casa da Moeda, 1985, pág.14.

16 J.J. Gomes Canotilho e Vital Moreira, “Constituição da República Portuguesa Anotada”, 3. Edição Revista, Coimbra Editora, 1993, anotação ao artigo 266º pág. 924 e José Carlos Vieira de Andrade, “Os Direitos Fundamentais na Constituição Portuguesa de 1976”, 3. ' Edição, Almedina, 2004, pág. 240.

${ }^{17}$ Maria Glória Garcia, “Estudos sobre o Principio”, cit., pág. 29-70
} 
de um alargamento desta compreensão do princípio.

Entramos numa segunda fase, em que o princípio da igualdade é entendido essencialmente como proibição do arbítrio. Há um apelo a critérios materiais de qualificação da igualdade, entendida em termos relativos, o princípio surge-nos aqui, como uma exigência de critérios razoáveis e suficientes, proibindo o arbítrio, na determinação da igualdade em função de um certo tratamento jurídico. Assim, embora já tenha uma abertura relativa à ideia de justiça material, continua, no entanto, ainda a ser entendido em termos formais (pois não se exige, em termos concretos, que seja este critério, e não aquele outro critério, bastando que o critério escolhido não tenha sido adoptado arbitrariamente). Surge, aqui a igualdade como limite externo dos poderes públicos.

Por último, entramos na terceira fase, na qual se alia aos conteúdos adquiridos das fases anteriores um maior desejo de justiça, assim surge-nos o princípio de igualdade ligado ao próprio sentido de justiça. O princípio da igualdade adquire uma nova função, a da realização da justiça. Há que discriminar para igualar. Aparece então a igualdade como um limite interno da actuação dos poderes públicos.

Desta evolução da compreensão do princípio da igualdade, que passou por estas três fases essenciais, resultou o sentido unitário que hoje reconhecemos ao princípio da igualdade, (acrescenta a ideia social e democrática ao pensamento liberal). Por um lado, temos a igualdade normativa, preocupada com a justiça da aplicação da norma - igualdade de todos perante a le $i$, o que tendencialmente implica a generalidade da norma -, ao lado uma igualdade jurídicopolítica angustiada com o critério material de qualificação igual para efeitos de tratamento jurídico, por outro lado, inquieta com a intencionalidade da norma - igualdade da própria lei. Critério e intencionalidade, que por sua vez se encontram ligados com o processo formativo de valores que lhes presidem - igualdade para o direito.

É este entendimento alargado do princípio da igualdade que nos oferece uma maior confiança nas suas grandes potencialidades, na luta contra as injustiças.

\subsection{O princípio da igualdade e o.$^{\circ}{ }^{0} 1$, do artigo $6^{\circ}$, do CPA}

São princípios importantes para a actividade administrativa, para além do princípio da igualdade, designadamente, o da legalidade, da imparcialidade, da justiça, da proporcionalidade, da protecção da confiança, da boa fé, da racionalidade, que são todos 
princípios da juridicidade substancial, explicitados na Constituição e na lei. ${ }^{18}$.

Quanto ao princípio da igualdade está consagrado no n. $^{\circ} 1$, do artigo 6. ${ }^{\circ}$ (corresponde ao artigo 5. ${ }^{\circ}$ do anterior Código), do CPA, que o prevê em termos gerais, “[n]as suas relações com os particulares, a Administração pública deve reger-se pelo principio da igualdade, não podendo privilegiar, beneficiar, prejudicar, privar de qualquer direito ou isentar de qualquer dever nenhum administrado em razão de ascendência, sexo, raça, língua, território de origem, religião, convicções politicas ou ideológicas, instrução, situação económica ou condição social ou orientação sexual”.

O princípio da igualdade decorre do princípio de justiça (previsto no n. ${ }^{\circ} 2$ do artigo $266 .^{\circ}$ da CRP e no artigo $8 .^{\circ}$ (antigo artigo $6^{\circ}$ ) do CPA, pretende dar a cada um o que lhe é devido. Para o princípio da igualdade, numa formulação clássica, situações iguais devem ter um tratamento igual, situações entre si diferentes devem ter um tratamento diferente, na medida dessa diferença.

Mas a igualdade ou desigualdade das situações da vida não têm de ser absolutas, têm é de se verificar nos aspectos que se afigurem relevantes à luz do poder administrativo concretamente exercido e do fim para o qual ele foi legalmente concedido, assim a igualdade ou diferença não são puramente fácticas, mas de qualificação jurídica.

Uma vez feita a qualificação jurídica entre situações, o princípio da igualdade num sentido negativo, implica que se não trate desigualmente o que deve ser igual, impondo à administração o dever de não agir de modo a introduzir desigualdades e num sentido positivo, implica que se trate de modo igual o que deve ser igual, impondo à administração o dever de agir no sentido de corrigir ou evitar desigualdades.

Quanto ao conteúdo da conduta que a Administração deve adoptar, distingue-se entre situações de proibição de discriminação e obrigação de discriminação, (para mais desenvolvimentos, ponto 2.1, deste artigo).

A proibição de discriminação tolhe toda a discriminação inaceitável, quer a que se reflecte em tratar de modo desigual o que deve ser igual, quer a tratar de modo igual o que é desigual, assim tanto se exige à Administração um dever de agir (tratando igualmente o que deve ser igual e impedindo que se trate desigualmente o que é igual), como se exige um dever de não agir (não introduzindo desigualdades no que deve ser igual ou introduzindo igualdades no que deve ser desigual). Quanto à obrigação de diferenciação subordina-se à ideia de introduzir tantas

\footnotetext{
${ }^{18}$ José Carlos Vieira de Andrade, “A Justiça Administrativa, (Lições)”, 7. ' Edição, Almedina, 2005, pág. 445.
} 
diferenciações quantas as necessárias para alcançar a igualdade substancial, quer tratando o desigualmente o que é igual e deve ser desigual, quer tratando desigualmente que é desigual e deve ser igual (discriminação positiva); aqui a Administração tem sempre dever de agir ${ }^{19}$.

\subsubsection{O princípio da igualdade como limite imanente da margem de livre decisão (do poder discricionário)}

Surgem-nos como limites imanentes do poder discricionários os princípios jurídicos da actividade administrativa previstos no . $^{\circ} 1$ e n. 2 do $\operatorname{artigo} 266 .^{\circ}$, da CRP, e artigo $3 .^{\circ}$ a $19 .^{\circ}$ do (novo) CPA. Entre eles inclui-se o princípio da igualdade. Estes princípios são limites de todas as condutas administrativas e não apenas das adoptadas no uso de poderes discricionários ${ }^{20}$, mas a sua violação por condutas administrativas vinculada não releva

${ }^{19}$ Neste ponto do trabalho, (3.2), seguimos de perto a obra, Marcelo Rebelo de Sousa e André Salgado Matos, "Direito Administrativo Geral: Introdução e Princípios Fundamentais", Tomo I, 2. ${ }^{\circ}$ Edição, Dom Quixote, 2006, pág. 222-223.

${ }^{20} \mathrm{~A}$ lei define sempre os fins e as competências do acto administrativo a praticar, quanto ao conteúdo é que pode dar uma margem de livre decisão à Administração. Assim, podemos ter actos de conteúdo vinculado ou actos de conteúdo discricionário.

A Discricionariedade é assim, uma concessão legislativa à Administração de um poder próprio na decisão de casos concretos (ou seja, um poder que lhe é concedido para que a Administração encontre aquela que considere ser a melhor solução para o caso concreto, que obviamente, só pode vir a ser uma.). Toda a actividade administrativa, mesmo ao abrigo de poderes discricionários, está hoje subordinada ao Direito, é jurídica, do ponto de vista funcional (porque visa encontrar a melhor solução para a realização do interesse publico legalmente definido), quer do ponto de vista substancial (está sujeita a princípios jurídicos, como o da boa fé, da imparcialidade, da igualdade e da proporcionalidade, que ao lhe fornecerem parâmetros da decisão, se mostram, deste modo, como limites da decisão administrativa discricionária). Nesta medida estão sujeita a uma fiscalização jurisdicional.

Assim, o critério de controlo que é feito pelos tribunais, quando administração actua ao abrigo de poderes discricionários, é mais vago, sendo constituído pelos princípios jurídicos, que como já vimos, norteiam e limitação a actuação da administração. Mas os tribunais já não apreciam do mérito da decisão da administração, sob pena de praticarem uma "dupla administração". Isto mesmo, nos refere expressamente, n. ${ }^{\circ} 1$, do artigo $3 .^{\circ}$ do Código do Processo dos Tribunais Administrativos (CPTA), " [n]o respeito pelo principio da separação de poderes e interdependência de poderes, os tribunais administrativos julgam do cumprimento pela Administração das normas e princípios jurídicos que a vinculam e não da conveniência ou oportunidade da sua actuação". O mérito das decisões administrativas engloba a apreciação de oportunidade (utilidade da concreta actuação administrativa para 
autonomamente, no caso de actos vinculados a Administração tem apenas de cumprir a lei, sob pena de praticar um acto ilegal ${ }^{21}$.

Nestes termos, o princípio da igualdade, como aliás todos os outros princípios jurídicos da actividade administrativa, só é fonte autónoma de invalidade no âmbito do uso de poderes discricionários da Administração.

\subsubsection{Autovinculação (casuística) da Administração no âmbito dos seus poderes discricionários}

Estando a actuar ao abrigo de poderes discricionários, reserva-se uma referência especial à ideia de autovinculação da administração, (regra do precedente), que se traduz na utilização de critérios substancialmente semelhantes para a resolução de casos semelhantes, traduzindo-se numa violação do princípio da igualdade uma mudança de critérios, sem qualquer fundamentação material: a Administração só pode afastar-se de uma prática anterior, que não seja ilegal (por não existir um direito à igualdade na ilegalidade), se ocorrerem alterações na "dimensão do interesse público prosseguido ou dos interesses particulares com ele comprometidos" 22 .

No entanto para que se possa falar em regra do precedente é necessário que se cumpram requisitos positivos e negativos ${ }^{23}$.

São requisitos positivos, a identidade subjectiva, as actuações têm de (a anterior e a actual) provir do meu órgão ou dos seus sucessores legais nessa competência, tem de haver também identidade objectiva - os elementos objectivos das situações concretas (pressupostos, procedimento e forma) têm de ser idênticos, por fim exige-se identidade normativa das situações em análise, identidade da disciplina jurídica.

Como requisito negativo diga-se que a precedente decisão da administração não pode ser ilegal,

\footnotetext{
a prossecução do interesse publico legalmente definido) e da conveniência (utilidade da concreta actuação administrativa para a prossecução do interesse publico legalmente definido à luz dos demais interesses públicos envolvidos). Vide Vieira de Andrade, “A Justiça Administrativa”, cit., pág. 94-98.

${ }^{21}$ Marcelo de Sousa e André Matos, "Princípios Fundamentais”, cit., pág. 201.

${ }^{22}$ Mário de Oliveira, Pedro Gonçalves e João Amorim, “Código do Procedimento Administrativo”, cit., pág. 100.

${ }^{23}$ Idem, pág. 101.
} 
não há "direito à igualdade na ilegalidade" - a jurisprudência tem vindo a ser unânime nesta conclusão.

\subsubsection{Limites à regra do precedente da actuação administrativa}

Por um lado, as vantagens que decorrem da autovinculação são evidentes, permitem aumentar a segurança, a previsibilidade e a certeza que podem decorrer da margem de livre decisão administrativa, por outro lado ao darem critérios de soluções acabados à Administração retiramlhe a necessidade da elaboração de juízos que podem vir a revelar-se complexos, constituindo assim um factor de desburocratização e celeridade das decisões administrativas ${ }^{24}$. No entanto, nem tudo são vantagens, não podem pois deixar de se apontar algumas desvantagens à autovinculação da Administração, assim admitir-se "a autovinculação da administração à decisão precedente não significa o reconhecimento da vinculatividade "das directivas de discricionariedade”, actos internos tendentes ao estabelecimento de critérios de aplicação uniforme da lei”. Até porque a lei que concede poderes discricionários à Administração implica uma proibição de desatender às circunstâncias do caso concreto, pelo que não pode uma "norma interna" vir transformar em vinculado um poder que a norma de competência quis que fosse discricionário ${ }^{25}$.

A este propósito, Marcelo Rebelo de Sousa e André Salgado Matos falam em limites à autovinculação da Administração. Primeiro, ao critérios decisórios que dela resultam não podem ser imutáveis, petrificados, porque em nome do poder discricionário tem de se admitir que quando for juridicamente necessário, ou apenas oportuno ou conveniente, possam ser revistos pela Administração, ou seja é necessário que possa existir uma autodesvinculação. Segundo, a autovinculação não dispensa o decisor administrativo de verificar se no caso concreto existem circunstâncias que exijam uma diferente ponderação dos interesses envolvidos; se tal acontecer o caso deve ser tido como atípico, (ou seja, saindo fora do âmbito da autovinculação) e como tal deve ser decidido sem recurso aos critérios pré-determinados ${ }^{26}$. Defendem também os citados autores, que os actos jurídicos que contém decisões de autovinculação apresentam uma natureza normativa, pois contém regras de conduta que se

\footnotetext{
${ }^{24}$ Marcelo de Sousa e André Matos, “Princípios Fundamentais”, cit. pág. 196.

${ }^{25}$ Mário de Oliveira, Pedro Gonçalves e João Amorim, “Código do Procedimento Administrativo”, cit. pág. 101 e 102.

${ }^{26}$ Marcelo de Sousa e André Matos, “Princípios Fundamentais”, cit. pág. 196.
} 
destinam a ser aplicadas a um número indeterminável de casos. No entanto, tais normas não têm eficácia externa, devido à possibilidade de no caso concreto serem afastadas e à reduzida vinculatividade que daí decorre ${ }^{27}$.

Também não deve exigir-se que a Administração anuncie antecipadamente a mudança dos seus critérios gerais e abstractos pré-determinados, pois pode acontecer que só se aperceba da necessidade, ou mérito (oportunidade ou conveniência) de tal mudança, precisamente aquando da decisão de um caso concreto. Assim, a mudança do critério decisório, bem como a não aplicação das instruções da autovinculação em casos atípicos, gera apenas a obrigação da correspondente fundamentação material específica, o que decorre da al. d) do n. ${ }^{\circ} 1$ do artigo 152..$^{\circ}$ do (novo) CPA, há o dever de fundamentação dos actos administrativos que, "decidam de modo diferente da prática habitualmente seguida na resolução de casos semelhantes (...)”. ${ }^{28}$

Nestes termos, o princípio da igualdade não proíbe a diversidade de tratamento, o que se veda é a "proibição de discriminações e segregações arbitrárias ou injustificadas", (ou seja "o estabelecimento de distinções sem fundamento racional e objectivo, ditadas pela irrazoabilidade e, pelo mero arbítrio”). O que importa “(...) é que não se discrimine para discriminar" 29 .

\subsubsection{A relevância prática do princípio da igualdade}

Retomando as palavras por nós usadas na introdução deste ensaio, o princípio da igualdade é teoricamente complexo e da aplicação prática extremamente difícil. Vamos tentar perceber porque esta concretização prática se afigura complicada ${ }^{30}$.

Invalidar uma actuação administrativa com base na violação do princípio da igualdade depende de dois pressupostos: a igualdade ou diferença entre duas situações da vida e entre os tratamentos que lhes foram dispensados. Este princípio como parâmetro de controlo da actividade discricionária da administração conta com uma operatividade limitada, isto é assim

\footnotetext{
27 Idem, pág.197.

${ }^{28}$ Ibidem, pág. 197.

${ }^{29}$ Vieira de Andrade, "Os Direitos Fundamentais na Constituição”, cit., pág. 280 e 311 e Acórdão do STA, Proc, n. ${ }^{\circ} 047525$, de $29 / 01 / 2002$.

${ }^{30}$ Marcelo de Sousa e André Matos, “Princípios Fundamentais”, cit., pág.224.
} 
porque: a actividade administrativa não sendo secreta, (podendo quem pretender fazer uso do direito fundamental à informação, n. ${ }^{\circ} 1$ do artigo $268^{\circ}$, da CRP e artigo $17 .^{\circ}$ e $82 .^{\circ}$ do novo CPA, e em geral, do princípio da colaboração da Administração com particulares, artigo $11 .^{\text {o }}$ do novo CPA), conta com uma publicidade limitada, e por isso não será fácil a quem tenha sido objecto de tratamento desigual demonstrá-lo em tribunal, ou mesmo, conhecer as situações similares à sua, que tiveram um tratamento diferente por parte da administração. Para além disto, é praticamente impossível encontrar duas situações da vida absolutamente idênticas, pelo que se afigura também complicado demonstrar que possíveis desigualdades no tratamento pela administração não ocorreram por diferenças das situações.

A relevância prática do princípio da igualdade aumenta consideravelmente enquanto parâmetro de controlo do poder discricionário da administração perante discriminações ocorridas no âmbito do mesmo contexto procedimental (por exemplo, relativos a dois concorrentes do mesmo concurso público).

Também, neste sentido, Rui Medeiros e Jorge Miranda, “[o] princípio da igualdade tem uma especial relevância prática no que respeita aos concursos de acesso à função pública ou de classificação e promoção a cargos e categorias da função pública. O princípio vale também para a retribuição dos funcionários públicos. Vale para os funcionários, o princípio "igual trabalho, igual salário" 31

Não é por acaso que grande parte das decisões dos tribunais administrativos de anulação de acto administrativos, por violação do princípio da igualdade ocorre no âmbito de concursos públicos $^{32}$.

\section{Conclusão}

O princípio da igualdade tem consagração constitucional em Portugal desde as Constituições Monárquicas do séc. XIX. Este princípio, tal como hoje o conhecemos, é o resultado de uma grande evolução a que esteve sujeito ao longo de quase dois séculos de existência.

Tem consagração na actual Constituição Portuguesa, (de 1976), no artigo $13^{\circ}$ e especificamente, quanto à actividade administrativa, no n. ${ }^{\circ} 2$ do artigo 266. ${ }^{\circ}$. No Código do Procedimento

\footnotetext{
${ }^{31}$ Rui Medeiros e Jorge Miranda, “Constituição Portuguesa Anotada”, Tomo III, Coimbra Editora, 2007, anotação ao artigo 266. ${ }^{\circ}$ pág. 570.

${ }^{32}$ Marcelo de Sousa e André Matos, "Princípios Fundamentais", cit., pág. 224
} 


\section{pontěditora}

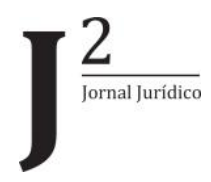

Administrativo está previsto actualmente no $\mathrm{n}^{\circ} 1$ do artigo $6 .^{\circ}$ (corresponde ao artigo $5 .^{\circ}$ do anterior CPA).

É um princípio importante ligado com a própria dignidade humana, que decorre do princípio de justiça, é teoricamente elaborado e na prática de difícil concretização.

Surge-nos ao lado de outros princípios jurídicos, como limite imanente da margem de livre decisão (discricionariedade) da Administração, relevando só neste âmbito como fonte autónoma de invalidade dos actos administrativos.

Implica que se trate o que igual de modo igual, e o que é desigual de modo desigual, na medida dessa diferença.

É um princípio relacional, uma vez que se vai comparar o critério decisório que a Administração adoptou em relação a um "caso precedente", para depois se houver identidade normativa, subjectiva e objectiva, o aplicar ao "caso posterior", é a "regra do precedente" ou autovinculação da Administração.

No entanto, a autovinvulação administrativa encontra importantes limites, deste modo só porque existe uma pré-determinação para que a Administração possa agir num determinado sentido, não pode nunca deixar de analisar as circunstâncias do caso concreto, que podem justificar o abandono da regra do precedente, sob pena de comprometer a norma de competência que lhe atribuiu poderes discricionários naquela matéria.

Nestes termos, a Administração não está obrigada a uma igualdade de tratamento, o que se veda é a mudança de critérios em relação a casos iguais, sem fundamentação material legítima, ou seja o que se proíbe é o arbítrio das decisões administrativas.

Na prática encontra vários obstáculos à sua aplicação, quem sofreu um tratamento violador do princípio da igualdade muitas vezes não consegue demonstrar, nem conhece as situações iguais à sua que tiveram um tratamento desigual pela Administração. Até porque é praticamente impossível ter duas situações absolutamente iguais, tornando-se difícil provar que a discriminação não surgiu devido a essas diferenças.

Estas dificuldades são superadas no âmbito de um mesmo contexto procedimental (como por ex. concursos públicos), onde o princípio tem grande operatividade. Não é por acaso que a grande parte das decisões do STA, que conduz à anulação de actos administrativos, por violação do princípio da igualdade ocorre no âmbito de concursos públicos.

Entendendo embora as razões que justificam a reduzida operatividade do princípio da igualdade, lamentamos no entanto que assim seja, pois sendo este um princípio estruturante do 
Estado de Direito Democrático e Social, ligado com a própria ideia de dignidade humana e com princípio de justiça achamos que devia ter uma maior relevância prática!

\section{Bibliografia}

ALBUQUERQUE, Martim, "Da Igualdade - Introdução à Jurisprudência”, Livraria Almedina, Coimbra, 2003.

ANDRADE, José Carlos Vieira de, “Os Direitos Fundamentais na Constituição Portuguesa de 1976", 3. ' Edição, Almedina, 2004.

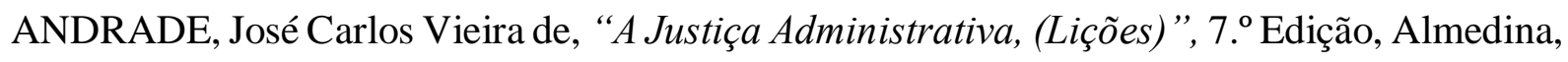
2005.

BRUXO, Jorge Baptista/ SILVA, Maria Aline Gago da, "Princípios Jurídicos da Administração Pública”, Imprensa Nacional - Casa da Moeda, 1985.

CANOTILHO, J.J. Gomes/ MOREIRA, Vital, "Constituição da Republica Portuguesa Anotada”, 3. ${ }^{\circ}$ Edição Revista, Coimbra Editora, 1993.

CANOTILHO, J.J. Gomes Canotilho/ MOREIRA Vital, "Constituição da República Portuguesa Anotada”, Vol. I, 4. ${ }^{\circ}$ Edição Revista, 2007.

FRANCO, João Melo/ MARTINS, António Herlander Antunes, "Dicionário de Conceitos e Princípios Jurídicos: na Doutrina e na Jurisprudência", 3. Edição, Almedina, 1993.

GARCIA, Maria Glória F.P.D., “Estudos sobre o Princípio da Igualdade”, Almedina, 2005.

MEDEIROS, Rui/ MIRANDA, Jorge, “Constituição Portuguesa Anotada”, Tomo III, Coimbra Editora, 2007. 


\section{pontěditora}

NOVAIS, Jorge Reis, “Os Princípios Constitucionais Estruturantes da República Portuguesa”, Coimbra Editora, 2004.

OLIVEIRA, Mário Esteves de/ GONÇALVES, Pedro Costa/ AMORIM, João Pacheco, “Código do Procedimento Administrativo - comentado”, 2. Edição, Março de 2005.

SOUSA, Marcelo Rebelo de/ MATOS, André Salgado, "Direito Administrativo Geral: Introdução e Princípios Fundamentais”, Tomo I, 2. ${ }^{\circ}$ Edição, Dom Quixote, 2006

${ }^{1}$ Abreviaturas e siglas utilizadas: Ac.(s) - Acórdão(s); al.(s) - alínea(s); AI - Administrador da

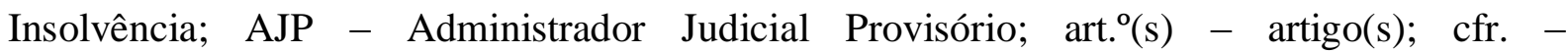
conferir/confrontar; CC - Código Civil; CIRE - Código da Insolvência e da Recuperação de Empresas, aprovado pela Lei n. ${ }^{\circ}$ 53/2004, de 18 de Março; CPC - Código de Processo Civil, aprovado pela Lei n. ${ }^{\circ}$ 41/2013, de 26 de junho; CRP - Constituição da República Portuguesa; CT - Código do Trabalho, aprovado pela Lei n. ${ }^{\circ}$ 7/2009, de 12 de fevereiro; CT 2003 - Código do Trabalho, aprovado pela Lei n. ${ }^{\circ}$ 99/2003, de 27 de agosto; DL - Decreto-Lei; FGS - Fundo de Garantia Salarial; NRFGS - Novo Regime do Fundo de Garantia Salarial, aprovado pelo Decreto-Lei n. ${ }^{\circ}$ 59/2015, de 21 de abril; RCT - Regulamentação do Código do Trabalho, aprovada pela Lei n. ${ }^{\circ}$ 35/2004, de 29 de Julho; n. ${ }^{\circ}(\mathrm{s})$ - número(s); PER - Processo Especial de Revitalização, introduzido no CIRE, dos artigos 17. ${ }^{\circ}$-A a 17. ${ }^{\circ}-H$, pela Lei n. ${ }^{\circ}$ 16/2012, de 20 de abril; TAF - Tribunal Administrativo e Fiscal; TCA-Norte - Tribunal Central Administrativo Norte; TCA-Sul - Tribunal Central Administrativo Sul; TJ - Tribunal de Justiça das Comunidades Europeias/Tribunal de Justiça da União Europeia.

$\mathrm{J}^{2}$ - Jornal Jurídico | Volume 1 | Número 1 


\title{
Fundo de Garantia Salarial - O prazo para requerer o pagamento dos créditos laborais
} e a sua (in)compatibilidade com o Direito Comunitário e a Constituição ${ }^{33}$

\author{
Salary Guarantee Fund - The time-limit for lodging applications for payment of outstanding \\ salary and its (in)compatibility with the Community Law and the Constitution
}

Inês Castelo Branco ${ }^{1}$;

${ }^{1}$ E-mail: icbranco@outlook.pt

Doutoranda na Faculdade de Direito

da Universidade de Coimbra |

Advogada na CRBA -

Sociedade de Advogados, RL
Resumo: O NRFGS passou a prever que o FGS só assegura o pagamento dos créditos laborais quando o pagamento lhe seja requerido até um ano a partir do dia seguinte àquele em que cessou o contrato de trabalho (art. ${ }^{\circ} 2 .^{\circ}$, n. $\left.^{\circ} 8\right)$. Esta alteração consubstancia uma alteração do prazo anterior, previsto no art. ${ }^{\circ}$ 319. ${ }^{\circ}$, n. 3 da RCT, porque o atual deixou de estar indexado ao prazo de prescrição dos créditos laborais, e, consequentemente, deixou de poder aproveitar as causas de interrupção deste. Os nossos tribunais têm sido chamados a dirimir litígios relacionados com a alteração deste prazo, mas, salvo o devido respeito, de maneira não totalmente satisfatória. A nosso ver, a referida norma não é compatível com a Diretiva 2008/94/CE, por violação do princípio da efetividade, nem com o art. $^{\circ} 59 .^{\circ}$, n. ${ }^{\circ}$ s 2 e 3 da CRP.

Palavras-chave: Fundo de Garantia Salarial; trabalhadores; insolvência do empregador.

Abstract: The new legal regime of the Salary Guarantee Fund stipulates that it only guarantees the payment of outsanding salary when it is required until one year from the day after of the termination of the labour contract (art. ${ }^{o}$ $\left.2 .^{o}, n .^{o} 8\right)$. There was a modification of the previous time-limit (art. ${ }^{\circ} 319 .^{o}, n .^{o}$ 3 of the Regulamentation of the Labour Code), because the current one is no longer related to the prescription time-limit of outstanding salary claims and, consequently, it is no longer possible to take advantage of interrupting causes. There are already some Court's decisions, however, with all due respect, not totally satisfactory. In our opinion, that art. ${ }^{\circ} 2 .^{\circ},{ }^{\circ} .^{o}$ do not respect the Directive 2008/94/CE, disregarding the principle of effectiveness, and the art. ${ }^{\circ} 59 .^{\circ},{ }^{\circ}{ }^{\circ} 2$ and 3 of the Constitution.

Keywords: Salary Guarantee Fund; workers; insolvency of the employer. 


\section{Introdução - os termos do problema}

Após uma espera de mais de 6 anos, através do DL n. ${ }^{\circ}$ 59/2015, de 21 de abril, que aprovou o NRFGS, concretizou-se a revogação do anterior regime jurídico do FGS, que se encontrava dispersamente previsto no CT 2003 (art. ${ }^{\circ} 380 .^{\circ}$ ), na RCT (arts. 316. ${ }^{\circ}$ a $326 .^{\circ}$ ) e no DL n. ${ }^{\circ}$ 139/2001, de 24 de abril.

Dessa forma, a partir de 4 de maio de 2015, data da sua entrada em vigor ( art. $^{\circ}$ 5. $^{\circ}$ ), a legislação específica a que se refere o art. $^{\circ} 336^{\circ}$ do CT passou a ser o NRFGS.

Neste artigo iremos analisar, somente, um dos aspetos do NRFGS - o prazo do trabalhador para requerer ao FGS o pagamento dos créditos emergentes do contrato de trabalho ou da sua violação ou cessação -, um dos aspetos, adiantamos já, que sofreu alteração.

O FGS assegura, aos trabalhadores, o pagamento dos seus créditos emergentes de contrato de trabalho, ou da sua violação ou cessação, que não possam ser pagos pelo empregador por motivo de insolvência ou de situação económica difícil (art. ${ }^{\circ} 380 .^{\circ}$ do CT 2003 e art. ${ }^{\circ} 336 .^{\circ}$ do CT).

No regime anterior, esse pagamento tinha de ser requerido (o mesmo é dizer, o direito do trabalhador a ser pago pelo FGS tinha de ser exercido) até três meses antes da prescrição dos créditos laborais cujo pagamento estava a ser reclamado ao FGS (art. ${ }^{\circ} 319 .^{\circ}$, n. $^{\circ} 3$ da RCT). Esta formulação obrigava-nos, então, a verificar o prazo de prescrição dos créditos laborais previsto no CT 2003, a qual ocorria um ano a partir do dia seguinte àquele em que cessou o contrato de trabalho (art. ${ }^{\circ} 381 .^{\circ}$, n. $^{\circ} 1$ ).

Por seu turno, o art. $^{\circ} 2 .^{\circ}$, n. $^{\circ} 8$ do NRFGS estabelece o prazo de um ano a partir do dia seguinte àquele em que cessou o contrato de trabalho.

Comparando a literalidade das duas normas, verificamos que, se anteriormente, o prazo para o exercício do direito estava indexado (Domingos, 2009, pp. 263 e 264) a outro prazo, o da prescrição dos créditos laborais, agora não está.

Essa diferença é, a nosso ver, essencial, dado que, anteriormente, como o prazo do trabalhador para requerer o pagamento ao FGS estava indexado a um prazo de prescrição, tínhamos de ter em atenção as situações de interrupção e suspensão desse prazo, previstas no CC, em particular, nos artigos $323 .^{\circ}$ e $327 .^{\circ}$.

Desse modo, e na verdade, "o prazo de reclamação desencade[ava-se] em momentos diferentes, variando de caso para caso, em função do momento em que cessou a relação laboral e em função da ocorrência ou não de suspensão ou interrupção do prazo de prescrição, nos termos dos artigos 
318. ${ }^{\circ}$ e seguintes do CC, pelo que, na verdade, este prazo de três meses pod[ia] ter a montante um período de tempo bastante alargado" (Domingos, 2009, pp. 263 e 264). No mesmo sentido, ia a jurisprudência, designadamente, o Ac. do STA, de 17/12/2014, processo n. ${ }^{\circ} 0632 / 12$, relator Carlos Carvalho, disponível na base de dados acessível em www.dgsi.pt.

Por exemplo, a reclamação de créditos no próprio processo de insolvência interromperia esse prazo, o qual não começaria a correr enquanto não transitasse em julgado a decisão que pusesse termo ao processo (que, no caso, seria a sentença de verificação e graduação de créditos).

Desse modo, salvo o devido respeito, não é inteiramente rigorosa a conclusão que o pagamento teria de ser requerido antes de terem passado nove meses do fim do contrato de trabalho (Abrantes, 2009, p. 412). Por via de regra, sim, mas era preciso ter em conta as situações de interrupção e suspensão.

E agora, com o NRFGS?

Deixando de haver essa indexação, a única data relevante para a contagem do prazo para o exercício do direito de reclamar o pagamento dos créditos laborais ao FGS é a data em que cessou o contrato de trabalho do trabalhador.

Ademais, se, anteriormente, ao prazo de prescrição de um ano e um dia teríamos de descontar três meses, agora temos um prazo contínuo de um ano a partir do dia seguinte àquele em que cessou o contrato de trabalho.

E, assim, tem entendido e decidido o FGS.

Sobre este ponto, o nosso legislador, no preâmbulo do DL n. ${ }^{o}$ 59/2015, de 21 de abril, assume a existência de uma alteração, quando afirma o seguinte: "Promovendo uma lógica de estabilidade temporal e de segurança jurídica manteve-se no novo regime a regra de que o FGS assegura o pagamento dos créditos que se tenham vencido nos seis meses anteriores à propositura da ação de insolvência ou à apresentação do requerimento do PER ou do procedimento extrajudicial de recuperação de empresas, atualmente o SIREVE, passando-se agora, no entanto, a prever que o pagamento dos créditos requeridos é assegurado até um ano a partir do dia seguinte àquele em que cessou o contrato de trabalho".

Esta alteração surgiu logo na versão inicial do projeto de DL sobre o FGS apresentado, pelo Governo, aos seus parceiros sociais em sede de Concertação Social, na reunião plenária de 6 de outubro de 2014, sendo que, das atas relativas às reuniões plenárias em que se discutiu este assunto (as atas n. ${ }^{\circ}$ 7/2014, da reunião plenária de 09.07.2014, n. ${ }^{\circ}$ 9/2014, da reunião plenária de 6/10/2014 e n. ${ }^{\circ}$ 10/2014, de 2/12/2014) não consta qualquer justificação para esta mudança, nem que esta mudança tivesse sido, sequer, contestada. 
Assim, esta alteração vingou até à versão final do diploma aqui em análise.

Por seu turno, a doutrina tem ido no sentido de que essa alteração correspondeu a um aumento em três meses do prazo anterior (Abrantes, 2015, p. 412 e Costeira, 2017, p. 144).

Sucede que, na prática, tem-se verificado que essa alteração, em alguns casos, tem correspondido a uma redução do prazo anterior.

E, igualmente, porque a este novo prazo ficaram sujeitos os requerimentos apresentados após o dia 4 de maio de 2015 (art. $^{\circ} 3^{\circ}$, $^{\text {n. }}{ }^{\circ} 1$ do DL n. ${ }^{\circ}$ 59/2015, de 21 de abril), tem-se verificado que esta alteração tem afetado contratos de trabalho que cessaram antes da entrada em vigor do NRFGS, quando os requerimentos foram apresentados após aquela data.

E, por isso, os nossos tribunais já têm sido chamados a dirimir litígios relacionados com a aplicação do art. $^{\circ}$ 2. $^{\circ}$, n. $^{\circ} 8$ do NRFGS, tendo sido, até à data em que escrevemos, publicados, na base de dados disponível em www.dgsi.pt, seis acórdãos de tribunais superiores, que aqui se enunciam, do mais antigo para o mais recente, tendo em conta a data do acórdão:

1) Ac. do TCA-Norte, de 28/04/2017, processo n. ${ }^{\circ}$ 00840/16.9BEPRT, relator Rogério Paulo da Costa Martins;

2) Ac. do TCA-Sul, de 01/06/2017, processo n. ${ }^{\circ}$ 3462/15.8BESNT, relator Helena Canelas;

3) Ac. do TCA-Norte, de 14/07/2017, processo n. ${ }^{\circ}$ 00698/16.8BEPNF, relator Rogério Paulo da Costa Martins;

4) Ac. do TCA-Norte, de 22/09/2017, processo n. ${ }^{\circ}$ 02277/16.0BEPRT, relator Alexandra Alendouro;

5) Ac. do TCA-Norte, de 4/10/2017, processo n. ${ }^{\circ}$ 00885/16.9BEPRT, relator Luís Migueis Garcia;

6) Ac. do TCA-Sul, de 10/05/2018, processo n. ${ }^{\circ}$ 690/16.2BEALM, relator Helena Canelas.

Damos, ainda, nota de que foi apresentado, a 5 de dezembro de 2016, pelo TAF de Viseu, junto do TJ, um pedido de decisão prejudicial (processo C-627/16, João Ventura Ramos/Fundo de Garantia Salarial), em que foram feitas as seguintes questões prejudiciais:

“Um prazo de caducidade aplicável ao pedido de pagamento pela instituição de garantia de créditos salariais em dívida é mais favorável aos trabalhadores assalariados, na aceção do artigo $11^{\circ}$ da Diretiva 2008/94/CE, do Parlamento Europeu e do Conselho, de 22 de outubro de 2008, relativa à proteção dos trabalhadores assalariados em caso de insolvência do empregador, quando só é assegurado o pagamento de tais créditos quando o pagamento seja requerido à 
instituição de garantia até um ano a partir do dia seguinte àquele em que cessou o contrato de trabalho ou se se contasse a partir da data da propositura da ação de insolvência, considerando que a instituição de garantia só assegura o pagamento dos créditos do trabalhador que se tenham vencido nos seis meses anteriores à sua propositura?

Se um trabalhador tiver deixado passar o prazo por razões de que não seja responsável, devem as legislações dos Estados-Membros, ao abrigo do disposto no artigo $11^{\circ}$ da Diretiva 2008/94/CE, do Parlamento Europeu e do Conselho, de 22 de outubro de 2008, prever um prazo adicional para a apresentação do seu pedido, desde que o trabalhador demonstre que não é responsável pela inobservância do prazo de caducidade?”.

Contudo, estas questões prejudiciais ficaram por responder (Serra, 2017, p. 167) porque, a 23 de março de 2017, o TJ cancelou o processo por ter deixado de haver um litígio pendente no tribunal português.

Voltando à jurisprudência nacional, da leitura dos seis acórdãos concluímos que, em todos, os contratos de trabalho cessaram antes da entrada em vigor do NRFGS (e quando nem sequer havia sido apresentado o referido projeto sobre a alteração do regime jurídico do FGS), mas todos foram entregues já na vigência do NRFGS:

1) Cessação do contrato de trabalho dos trabalhadores: 19/09/2013 e 05/09/2013; ação laboral, em que houve reconhecimento dos créditos laborais; início do processo de insolvência relevante para o FGS: 04/11/2014; entrega dos requerimentos: 14/07/2015 e a $15 / 07 / 2015$.

2) Cessação do contrato de trabalho, por revogação, com pagamento prestacional de compensação pecuniária de natureza global: 06/06/2013; ação laboral:10/02/2014, com trânsito em julgado a 28/04/2015; início do processo de insolvência: 26/03/2015; entrega do requerimento: 12/06/2015.

3) Cessação do contrato de trabalho: 13/11/2013 ou 18/02/2014 ${ }^{34}$; início do processo de insolvência: 26/12/2013; verifcação ulterior de créditos: 03.07.2014; entrega do requerimento: 30/10/2015.

4) Cessação do contrato de trabalho: 30/12/2013; início do PER: 15/02/2013; entrega do requerimento: 18/08/2015.

\footnotetext{
${ }^{34}$ Cremos que haverá algum lapso nos factos provados, porque surgem estas duas datas como a da cessação do contrato de trabalho.
} 
5) Cessação do contrato de trabalho: 07/05/2014; ação laboral:04/12/2014, com trânsito em julgado a 10/02/2015; entrega do requerimento: 03/06/2015.

6) Cessação do contrato de trabalho, por revogação, com pagamento prestacional de compensação pecuniária de natureza global: 30/11/2012; início PER: 14/08/2013, com despacho de homologação em 11/04/2014; declaração de insolvência (não é disponibilizada a data de início do processo): 08/06/2015; entrega do requerimento: $24 / 08 / 2015$.

O FGS indeferiu os requerimentos dos trabalhadores, por não terem sido apresentados no prazo de 1 ano a partir do dia seguinte àquele em que cessou o contrato de trabalho, nos termos do art. $^{\circ}$ 2. $^{\circ}$, no 8 do NRFGS (cfr. todos os Acs.), não estando em causa qualquer prazo de prescrição, mas sim de caducidade (cfr. o Ac. n. ${ }^{\circ}$ 2).

Foram duas as teses assumidas, com consequências opostas.

Por um lado, temos os que consideraram que, se, do caso concreto, o prazo, de caducidade, previsto no art. ${ }^{\circ}$ 2. $^{\circ}$, n. 8 do NRFGS, se mostrar mais curto do que o prazo previsto no art. ${ }^{o}$ 319. ${ }^{\circ}$, n. $^{\circ} 3$ da RCT, impor-se-á, então, o recurso ao art. ${ }^{\circ} 297 .{ }^{\circ}$, n. ${ }^{\circ} 1$ do CC, e, em consequência, o prazo de um ano só começará a contar a partir da data da entrada em vigor do NRFGS, a 4 de maio de 2015 (cfr. os Acs. n. ${ }^{\circ}$ s 1, 4, 5 e 6). Se assim for, será tempestivo o exercício do direito dos trabalhadores.

Por outro lado, temos os que consideraram que o novo prazo é um prazo de caducidade, que, por isso, nos termos do art. $328 .^{\circ}$ do $\mathrm{CC}$, não se suspende ou interrompe, estando expressamente fixado na letra da lei o início da contagem desse prazo, o dia seguinte àquele em que cessou o contrato de trabalho (cfr. os Acs. n. ${ }^{o}$ s $2^{35}$ e 3). Foi, por isso, considerado intempestivo o exercício do direito dos trabalhadores.

Quanto ao primeiro grupo, para chegarem a tal decisão, começaram por afirmar que o prazo estabelecido no art. $^{\circ} 2 .^{\circ}$, n. $^{\circ} 8$ do NRFGS é um prazo de caducidade e que esse prazo era o aplicável àqueles trabalhadores, porque os requerimentos foram apresentados após a entrada em vigor do DL n. ${ }^{\circ}$ 59/2015, de 21 de abril.

\footnotetext{
${ }^{35}$ Regista-se a mudança de posição da relatora e da adjunta deste Ac. que, mais tarde, subscreveram o Ac. n. ${ }^{\circ} 6$.
} 
Contudo, em sintonia com o princípio do Estado de Direito e da tutela da confiança, subjacentes ao princípio que as leis se aplicam para futuro, nos termos do art. ${ }^{\circ} 12 .^{\circ}$ do $\mathrm{CC}$, não pode, sem mais, ser aplicado este novo prazo (cfr., em particular, o Ac. n. ${ }^{\circ}$ 6).

Desse modo, há que ter em atenção o art. ${ }^{\circ} 297 .^{\circ}$, n. $^{\circ} 1$ do CC, de acordo com o qual se a lei estabelecer um prazo mais curto do que o fixado na lei anterior é também aplicável aos prazos que já estiverem em curso, mas o prazo só se conta a partir da entrada em vigor da nova lei. As instâncias superiores averiguaram, então, se o prazo anterior ainda estava em curso aquando da entrada em vigor do NRFGS e, em caso afirmativo, se, na situação concreta, o novo prazo se mostrava mais curto que o antigo, tendo em conta que este se encontrava indexado ao prazo de prescrição dos créditos laborais, o que implicava considerar as causas de interrupção e suspensão, e que novo prazo voltaria a correr.

Nos Acs. n. ${ }^{\circ}$ s 1,5 e 6, foi considerado que, ao abrigo do $\operatorname{art}^{\circ} 323 .^{\circ}$, n. $^{\circ} 1$ do CC, houve interrupção do prazo de um ano de prescrição com a instauração da ação laboral (cfr. os Acs. n. ${ }^{\circ} 1$ e 5) e com a reclamação de créditos no PER e no processo de insolvência (cfr. o Ac. n. ${ }^{\circ}$ 6), que inutilizaram o prazo entretanto decorrido ( $\operatorname{rrt}^{\circ} 326^{\circ}$, n. $^{\circ} 1$ do CC), e que começou a correr um novo prazo após transitar em julgado a decisão judicial que pôs termo ao litígio (arts. $326^{\circ}$, n. $^{\circ} 1$ e $327 .^{\circ}$, n. $^{\circ} 1$ do CC), o prazo ordinário, de 20 anos, porque houve sentença a reconhecer os créditos laborais (arts. $311 .^{\circ}$, n. $^{\circ} 1$ e $309 .^{\circ}$ do CC),

Consequentemente, na prática, para aqueles casos, a lei nova estabelecia um prazo mais curto, pelo que era aplicável o art. ${ }^{\circ} 297 .^{\circ}$, n. $^{\circ} 1$ do CC e, assim, o prazo de um ano de caducidade só começaria a contar a partir de 4 de maio de 2015 e o exercício do direito caducaria a 4 de maio de 2016. Por isso, os requerimentos foram entregues tempestivamente.

No Ac. n. ${ }^{\circ}$, o tribunal considerou intempestivo o exercício do direito do trabalhador porque entendeu que "não resulta da factualidade assente qualquer causa de interrupção da prescrição dos créditos laborais requeridos pelo Recorrente, de molde a permitir ao tribunal formar convicção no sentido do novo prazo se mostrar, em concreto, mais curto do que o previsto na lei antiga. Antes resulta que o prazo para a apresentação do requerimento ao FGS já se encontrava esgotado, aquando da entrada em vigor da nova lei, seja de acordo com a antiga seja com aquela, não cabendo assim chamar à colação o disposto no artigo 297. o do CC que regula situações em que os prazos se iniciem ou já se encontre em curso à data da entrada em vigor da lei nova".

Quanto ao segundo grupo, aplicaram o regime jurídico da caducidade, nomedamente, que os prazos de caducidade não se suspendem nem se interrompem (art. ${ }^{o} 328 .^{\circ}$ do $\mathrm{CC}$ ), que a lei 
pode fixar a data em que começa a correr esses prazos ( art. $^{\circ} 329 .^{\circ}$ do CC) e que só impede a caducidade a prática do ato dentro do prazo legal (art. ${ }^{\circ} 331$. $^{\circ}$, n. ${ }^{\circ} 1$ do CC). Por isso, concluíram que a instauração da ação judicial para condenação da entidade patronal no pagamento dos seus créditos laborais (cfr. o Ac. n. ${ }^{\circ}$ 2), ou a instauração e pendência do processo de insolvência ou de graduação de créditos (cfr. o Ac. n. ${ }^{\circ}$ ), não interrompeu ou suspendeu o prazo de um ano previsto no artigo $2 .^{\circ}$ n. ${ }^{\circ} 8$ do NRFGS.

De particular, no Ac. n. ${ }^{\circ} 2$ foi, igualmente, defendido que esta era uma interpretação conforme com a Diretiva 2008/94/CE, com a jurisprudência comunitária (Ac. do TJ, de 28.11.2013, processo C-309/12, e o Despacho, de 10.04.2014, processo n. ${ }^{\circ}$ C-511/12) e que não havia qualquer infração aos arts. 59..$^{\circ}$ n. ${ }^{\circ} 1$, a) e $13 .^{\circ}$ da CRP.

E, relativamente ao Ac. n. ${ }^{\circ}$ 3, segundo nos parece, foi entendido que esta posição respeitaria a finalidade social da Diretiva, "que justifica que sejam adoptados limites à sua intervenção, não só limites temporais que decorrem do enquadramento comunitário que lhe está subjacente (Directiva 80/987/CE, de 20.10), como também, limites às importâncias pagas".

Aparte da dissonância exposta, de comum, todos os Acs. afirmam que tanto o anterior prazo, como o atual, são prazos de caducidade, de acordo com o art. $^{\circ} 298 .^{\circ}$, n. $^{\circ} 1$ do CC, e que, com o NRFGS, houve uma alteração do prazo. Pelo que, a alteração do prazo não modificou a sua natureza (cfr., em particular, os Acs. n. ${ }^{\circ}$ s 1 e 6).

Ora, ainda que, entre os dois grupos, nos pareça mais acertado o decidido pelo primeiro, salvo o devido respeito, nem um, nem outro dão uma resposta cabalmente satisfatória à questão, porque, a nosso ver, não foi tida em devida conta o contexto normativo e jurisprudencial, nacional e comunitário.

\section{Apreciação crítica}

\subsection{Contextualização}

No seio comunitário, a proteção dos créditos dos trabalhadores é assegurada através de instituições de garantia.

A Diretiva n. ${ }^{\circ}$ 80/987/CEE, do Conselho, de 20 de outubro de 1980, relativa à aproximação das legislações dos Estados-membros respeitantes à proteção dos trabalhadores assalariados em caso de insolvência do empregador, determinou, pela primeira vez na Comunidade Europeia, que os Estados-membros tomariam as medidas necessárias para que fosse assegurado por 
instituições de garantia o pagamento dos créditos dos trabalhadores quando os empregadores se encontrassem em estado de insolvência ( $\operatorname{arts.} 1 .^{\circ}$ e $3 .^{\circ}$ ).

Esta Diretiva enquadrou-se nos desígnios da Comunidade Europeia promover o regular funcionamento do mercado comum e a melhoria das condições de vida e de trabalho, através da harmonização das legislações nacionais (arts. $1000^{\circ}$ e $117 .^{\circ}$ do Tratado que instituiu a Comunidade Económica Europeia, de 1957). Tinha, portanto, uma finalidade social $\left(\right.$ art. $^{\circ} 4 .^{\circ}$, n. 3 da Diretiva).

Entretanto, a Diretiva 80/987/CEE foi alterada, nomeadamente e substancialmente, pela Diretiva n. ${ }^{\circ}$ 2002/74/CE, do Parlamento Europeu e do Conselho, de 23 de Setembro, pelo que se procedeu à codificação daquela, incorporando, na versão original, as alterações que, entretanto, a mesma sofreu, o que foi feito através da Diretiva n. ${ }^{\circ}$ 2008/94/CE, do Parlamento Europeu e do Conselho, de 22 de Outubro de 2008, relativa à proteção dos trabalhadores assalariados em caso de insolvência do empregador (versão codificada).

A nível nacional, com inspiração na Diretiva 80/987/CEE (Domingos, 2009, p. 251), o nosso primeiro diploma a prever um sistema de garantia salarial foi o DL n. ${ }^{\circ} 50 / 85$, de 27 de fevereiro, regulamentado pelo Despacho Normativo n. ${ }^{\circ}$ 90/85, de 20 de setembro. À altura, foi já estabelecido um prazo para a apresentação, pelo trabalhador, do requerimento para pagamento dos créditos emergentes do contrato de trabalho, no caso, trinta dias contados a partir da data da cessação do contrato de trabalho decorrente da extinção, falência ou insolvência da entidade empregadora (ponto IV, n. ${ }^{\circ} 2$ do Despacho Normativo n. ${ }^{\circ}$ 90/85, de 20 de setembro).

Seguiu-se o DL n. ${ }^{\circ}$ 219/99, de 15 de junho, o qual instituiu o FGS (art. ${ }^{\circ}$ 1. $^{\circ}$ ), e compatibilizou a nossa lei com a Diretiva 80/987/CEE (cfr., nomeadamente, o preâmbulo do diploma).

Na sua versão original, não era previsto um prazo para a entrega do requerimento de pagamento dos créditos pelo FGS, mas acabou por sê-lo, através do DL n. ${ }^{\circ}$ 139/2001, de 24 de abril.

Este diploma aditou um n. 2 ao art. $^{\circ} 7 .^{\circ}$ do DL n. ${ }^{\circ}$ 219/99, de 15 de junho, com a seguinte redação: "[R]elativamente a créditos referentes a contratos de trabalho extintos e caso o seu titular não interrompa, por qualquer motivo, a respectiva prescrição, o requerimento referido no número anterior deve ser apresentado no prazo de nove meses a contar do início da contagem do prazo prescricional".

Esse aditamento, segundo consta do preâmbulo do DL n. ${ }^{\circ}$ 139/2001, de 24 de abril, teve em vista "permitir que o Fundo, perante um requerimento de pagamento de créditos relativos a contratos de trabalho já extintos, tenha tempo de desenvolver as diligências necessárias à respectiva recuperação antes da prescrição dos referidos créditos". Assim, o FGS disporia "de 
um prazo razoável (pelo menos 3 meses) para averiguação da existência e para a recuperação dos créditos antes da respectiva prescrição" (Pires, 2015, p. 265).

No âmbito do CT 2003 e da RCT, tendo em mente o que já apontámos, a redação mudou (art. ${ }^{o}$ 319. ${ }^{\circ}$, n. $^{\circ} 3$ da RCT), mas o sentido normativo manteve-se.

E, por último, atualmente, temos o art. $^{\circ} 2 .^{\circ}$, n. $^{\circ} 8$, do DL n. ${ }^{\circ}$ 59/2015, de 21 de abril. Portanto, como se verifica, o nosso FGS tem origem no direito comunitário.

Assim, fruto dessa origem, "esta figura deverá ser construída e interpretada nesse quadro" (Monteiro, 2016, p. 149), “o que significa que a interpretação dos normativos nacionais haverá de ser feita em conformidade (interpretação conforme)" (cfr. o Ac. n. ${ }^{\circ}$ 2).

Essa interpretação conforme resulta, aliás, do $\operatorname{art}^{\circ}{ }^{\circ} .^{\circ}$, n. $^{\circ} 4$ da CRP.

Quanto ao nosso objeto de análise, verificamos que, nem a Diretiva 80/987/CEE, na sua versão original ou com as subsequentes alterações, nem a Diretiva 2008/94/CE estabelecem qualquer prazo para os trabalhadores acionarem o FGS (Domingos, 2009, p. 251).

Perante esta omissão, colocou-se, perante o TJ, a questão de saber se era compatível com a Diretiva (no caso, a Diretiva 80/987/CE) a previsão, por parte dos Estados-membros, de um prazo para os trabalhadores reclamarem o pagamento dos seus créditos junto das instituições de garantia, o qual, se não fosse cumprido, precludiria o direito.

Estamos a referir-nos ao Ac. de 18.09.2003, processo n. ${ }^{\circ}$ C-125/01, Peter Pflücke contra o Bundesanstalt für Arbeit ${ }^{36}$. Peter Pflücke trabalhou numa empresa alemã, até à sua demissão, que produziu efeitos em 30/06/1997, sendo que a empresa lhe ficou a dever o salário desse mês. Entretanto, esta foi objeto de um processo de falência, aberto a 02/01/1998. Segundo o direito alemão, o trabalhador, para obter o pagamento do seu crédito pela instituição de garantia competente, o Bundesanstalt, teria de ter feito o pedido no prazo de dois meses a partir de 02/01/1998, ou seja, entre 03/01/1998 e 02/03/1998. O que não fez.

$\mathrm{O}$ TJ retirou do facto de a Diretiva não prever qualquer limitação quanto à possibilidade de os Estados-membros estabelecerem um prazo de caducidade, que estes são, em princípio, livres de o fixar. Por outro lado, assim o justifica o bom funcionamento da instituição de garantia. $\mathrm{Na}$ condição, todavia, de serem respeitados os princípios gerais do direito comunitário.

Assim, o TJ declarou que a Diretiva não se opunha, "na condição de que esse prazo não seja menos favorável do que os prazos relativos a pedidos similares de natureza interna (princípio

${ }^{36}$ Disponível, nomeadamente, através da url https://curia.europa.eu/jcms/jcms/j_6/pt/. 
da equivalência) e não seja adoptado de modo a tornar na prática impossível o exercício dos direitos reconhecidos pela ordem jurídica comunitária (princípio da efectividade)", sendo que o "órgão jurisdicional nacional deve, se considerar que a disposição nacional que estabelece o prazo de caducidade não está em conformidade com as exigências do direito comunitário e que, além disso, nenhuma interpretação conforme dessa disposição é possível, recusar aplicá-la”.

Este entendimento voltou a ser seguido pelo TJ no Ac. de 16.07.2009, processo n. ${ }^{\circ}$ C-69/08, Raffaelo Visciano contra Istituto nazionale della previdenza sociale.

Pelo que se impõe a pergunta: o prazo previsto no art. ${ }^{\circ} 2 .^{\circ},{ }^{\circ} .^{\circ} 8$ do NRFGS respeita o princípio da equivalência e/ou o princípio da efetividade?

Sem prescindir, impõe-se, também, outra pergunta: será constitucional?

Ainda ao abrigo do DL n. ${ }^{\circ}$ 50/85, de 27 de fevereiro, se defendia que a ampliação das atribuições do sistema de garantia salarial era juridicamente defensável porque com tal sistema o Estado cumpria a sua expressa incumbência constitucional de assegurar a retribuição a que os trabalhadores têm direito, nos termos do art. $^{\circ}$ 59..$^{\circ}$, n. 2 da CRP (Amado, 1994, p. 164).

Mais tarde, na revisão constitucional de 1997, foi acrescentada, no novo n. ${ }^{\circ}$ 3, a imposição constitucional dos salários gozarem de garantias especiais, nos termos da lei (Canotilho e Moreira, 2014, p. 777).

Com respaldo constitucional desde 1997, a verdade é que, desde que foi instituído no nosso país um sistema de garantia salarial, que os créditos dos trabalhadores passaram a gozar de uma garantia especial, uma espécie de garantia pessoal, em que o Estado funcionaria como um fiador “ope legis" da obrigação retributiva (Amado, 1994, p. 162). Contudo, o nosso legislador laboral

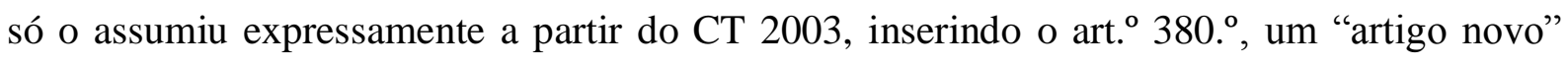
(AAVV, 2004, p. 624), na secção relativa às garantias dos créditos dos trabalhadores.

\subsection{Confronto com o Direito Comunitário e com a Constituição da República Portuguesa}

Em primeiro lugar, no ponto anterior, perguntámos: o prazo previsto no $\operatorname{art}^{\circ}{ }^{\circ} 2 .^{\circ}$, n. $^{\circ} 8$ do NRFGS respeita o princípio da equivalência e/ou o princípio da efetividade?

Sendo dois princípios diferentes, temos, metodologicamente, de subdividir a pergunta. Assim, o prazo do art. ${ }^{\circ}$ 2. $^{\circ}$, n. $^{\circ} 8$ do NRFGS é menos favorável do que os prazos relativos a pedidos similares (princípio da equivalência), no caso, outros prazos estabelecidos pelo direito interno relativamente à reclamação de créditos (Domingos, 2009, p. 263)?

Julgamos que o problema não será (tanto) com este princípio. 
Com efeito, pegando nos exemplos já dados pela doutrina (Domingos, 2009, p. 263), o prazo (um ano) será, até, superior, porque o prazo de reclamação de créditos do processo de insolvência é, no máximo, de trinta dias ( $\operatorname{art}^{\circ}{ }^{\circ} 36^{\circ}$, j) do CIRE) e o prazo de reclamação de créditos na execução comum é de quinze dias ( $\operatorname{art}^{\circ}{ }^{\circ} 788 .^{\circ}$, n. $^{\circ} 2$ do CPC).

Já olhando para o prazo que o trabalhador dispõe para reclamar créditos junto da sua entidade patronal, é também um prazo de um ano (art. ${ }^{\circ} 337 .^{\circ}$ do CT), que começa, da mesma forma, a contar a partir do dia seguinte ao da cessação do contrato de trabalho - até aqui há, até, uma equivalência absoluta -, mas com uma diferença essencial, que pode fazer perigar o cumprimento deste princípio: por ser um prazo de prescrição, pode ser interrompido $\left(\operatorname{art}^{\circ}{ }^{\circ} 323 .^{\circ}\right.$ do CC); o do art. $^{\circ}$ 8. ${ }^{\circ}$, n. 2 do NRFGS, sendo de caducidade, não pode (art. $.^{\circ} 328 .^{\circ}$ do CC). Assim, e como ficou bem demonstrado no Acs. elencados no primeiro grupo, este último prazo pode ser manifestamente menos favorável do que aquele prazo.

É, aliás, essa diferença essencial que tornava o prazo anterior do art. ${ }^{\circ} 319 .^{\circ}$ da $\mathrm{RCT}$ conforme com o Direito Comunitário (Domingos, 2009, pp. 263 e 264) e torna o atual desconforme, se não pelo princípio da equivalência, indubitavelmente, pelo princípio da efetividade.

Pergunta-se, então: o prazo do art. ${ }^{\circ} 2^{\circ}$, n. $^{\circ} 8$ do NRFGS torna, na prática, impossível o exercício dos direitos reconhecidos pela ordem jurídica comunitária (princípio da efetividade), no caso, o direito dos trabalhadores ao pagamento dos créditos laborais em dívida, em caso de insolvência do empregador, por instituição de garantia?

Sim. Ou, mais rigorosamente, pode tornar.

O pagamento a um trabalhador, pelo FGS, de créditos emergentes do contrato de trabalho ou da sua violação ou cessação depende, nos termos do art. ${ }^{\circ} 1 .^{\circ}$, n. $^{\circ} 1$, alíneas a), b) e c) do NRFGS, da declaração da insolvência do empregador, ou de ser proferido despacho do juiz a designar o AJP, em caso de PER, ou de ser proferido despacho de aceitação do requerimento proferido pelo IAPMEI.

O requerimento do trabalhador a solicitar o pagamento dos créditos laborais ao FGS tem de ser instruído, de acordo com o art. $^{\circ} 5^{\circ}$, n. $^{\circ}$ 2, a) do NRFGS, com declaração comprovativa da natureza e do montante dos créditos em dívida declarados no requerimento pelo trabalhador.

Assim, para que o trabalhador possa entregar o seu requerimento devidamente instruído, tem de, por um lado, haver declaração de insolvência ou início do PER ou do procedimento extrajudicial de recuperação de empresas, e, por outro lado, nesses processos, ter havido reclamação de créditos. 
O processo de insolvência pode ter início por pedido apresentado pelo próprio devedor (art. ${ }^{\circ}$ 18..$^{\circ}$ do CIRE) ou por qualquer credor ou pelo Ministério Público, em representação das entidades cujos interesses lhe estão legalmente confiados (art. ${ }^{\circ} 20 .^{\circ}$ do CIRE).

No caso da apresentação à insolvência por parte do devedor, que deve acontecer dentro dos trinta dias seguintes à data do conhecimento da situação de insolvência (art. ${ }^{\circ} 18 .^{\circ}$, n. $^{\circ} 1$ do CIRE), por esta apresentação implicar o reconhecimento da sua situação de insolvência, a declaração ocorrerá, se cumprido o art. $^{\circ} 28$. $^{\circ}$ do CIRE, até ao terceiro dia útil seguinte ao da distribuição da petição inicial ou, existindo vícios corrigíveis, ao do respetivo suprimento.

No caso de a insolvência ser requerida por outros legitimados, os requisitos e a tramitação processual até à declaração da insolvência é mais complexa e demorada:

i) Estes legitimados só podem requerer a insolvência se se verificar a existência de algum dos factos-índice previstos no art. $^{\circ} 20 .^{\circ}$, n. $^{\circ} 1$ do CIRE como, por exemplo, no que diz respeito a créditos laborais, se houver um incumprimento generalizado, nos últimos seis meses, de dívidas emergentes de contrato de trabalho, ou da sua violação ou cessação (art. ${ }^{\circ}$ $20 .^{\circ}$, n. $\left.^{\circ} 1, \mathrm{~g}\right)$, iii) do CIRE).

ii) Depois de apresentado o requerimento de declaração de insolvência, se cumprido o art. ${ }^{\circ}$ 29. ${ }^{\circ}$ do CIRE, até ao terceiro dia útil seguinte ao da distribuição da petição inicial, o tribunal manda citar pessoalmente o devedor; pode, ainda, acontecer que, antes de ser determinada a citação do devedor, seja concedido ao requerente prazo para corrigir vícios sanáveis (art. ${ }^{\circ}$ 27. ${ }^{\circ},{ }^{\circ}$ 1, b) do CIRE).

iii) Sendo citado, o devedor tem prazo de dez dias para deduzir oposição (art. ${ }^{\circ} 30 .^{\circ}$, n. $^{\circ} 1$ do CIRE).

iv) Se se opuser, é marcada audiência de discussão e julgamento para, se cumprido o art. ${ }^{\circ}$ $35 .^{\circ}$, n. $^{\circ} 1$ do CIRE, um dos cinco dias subsequentes; e, se não logo, no prazo de cinco dias, é declarada sentença de insolvência ( art. $^{\circ} 35^{\circ}$, n. $^{\circ} 8$ do CIRE).

v) Se não se opuser, a insolvência é declarada, se cumprido o art. ${ }^{\circ} 30 .^{\circ}$, n. $^{\circ} 5$ do CIRE, no dia útil seguinte ao termo do prazo de dez dias que o devedor tinha para deduzir oposição.

Só nesta fase, é fácil concluir como há muitos fatores que o trabalhador não controla, e que a ele são alheios, e que podem, facilmente, influir no esgotamento do prazo para entrega do referido requerimento. Por exemplo:

i) O trabalhador, para requerer a insolvência do seu empregador, só o poderá fazer se se verificar a existência de algum dos factos índices previstos no art. $^{\circ} 20 .^{\circ}$ do CIRE, o que pode 
significar ter de esperar que as dívidas emergentes de contrato de trabalho, da sua violação ou cessação perfaçam seis meses.

ii) Se ainda não se verificar a existência desses factos índices, só o devedor pode apresentarse à insolvência, tendo da mesma conhecimento (art. ${ }^{\circ} 18 .^{\circ}$, n. $\left.^{\circ} 1\right)$.

iii) $\mathrm{Na}$ fase da citação do devedor várias vicissitudes podem ocorrer (ex vi art. $^{\circ} 17 .^{\circ}$ do CIRE), dilatando o período que medeia entre o despacho de citação e a efetivação da citação: não ser possível a entrega da carta da citação por via postal e a carta ficar depositada em estabelecimento postal, até oito dias (art. ${ }^{\circ} 228 .^{\circ}$, n. $^{\circ} 5$, para as pessoas singulares e art. ${ }^{\circ} 246 .^{\circ}$, para as pessoas coletivas, ambos do CPC); não haver levantamento da carta nesse prazo e, em consequência, ser devolvido o expediente; repetição da citação por via postal, no caso de pessoa coletiva, com possibilidade de se verificar, novamente, a não assinatura do aviso de receção, em que a citação se considera efetuada no oitavo dia posterior à data em que foi deixado o aviso (arts. 246..$^{\circ}$ e 230. ${ }^{\circ}$, n. ${ }^{\circ} 2$ do CPC); recurso à citação por agente de execução ou por mandatário judicial, em que o citando não seja encontrado de imediato, ou nem sequer seja encontrado (arts. 231. $.^{\circ}, 237 .^{\circ}, 238 .^{\circ}$ e $246 .^{\circ}$, todos do CPC); o citando se encontrar em parte incerta, em que se recorrerá à citação edital (arts. $236 .^{\circ}, 240 .^{\circ}$ e $241 .^{\circ}$, todos do CPC). É certo que pode ser dispensada a audiência do devedor, nos termos do art. ${ }^{\circ} 12 .^{\circ}$ do CIRE, mas tal só é possível se a audiência acarretar demora excessiva, pelo facto do devedor residir no estrangeiro ou ser desconhecido o seu paradeiro.

iv) Efetuada a citação, o devedor pode opor-se à insolvência até ao terceiro dia útil subsequente ao termo do prazo (art. ${ }^{\circ} 139 .^{\circ}$, n. $^{\circ} 5$ do CPC, ex vi art. ${ }^{\circ} 17 .^{\circ}$ do CIRE).

v) E, se houver oposição, pode haver audiência de discussão e julgamento.

E não é à toa que se disse, várias vezes, se cumprido o previsto em $x$ artigo. Como é do conhecimento geral, o volume de processos nos tribunais faz com que, na maior parte dos casos, seja impossível cumprir os prazos previstos na lei. Fora que, na prática, há ainda que ter em conta que os atos do tribunal são antecedidos pelas conclusões eletrónicas, e que estas não ocorrem logo, em alguns tribunais, ocorrem, até, só uma vez por semana.

Deste modo, mesmo que se esteja perante um trabalhador diligente, que toma a iniciativa de dar início ao processo de insolvência da sua entidade patronal, até à declaração da insolvência, por causa do que referimos, pode, desde a cessação do seu contrato de trabalho, já se ter volvido vários meses, possivelmente, mais de seis meses.

Além disso, como o requerimento para pagamento de créditos laborais pelo FGS tem de ser instruído com declaração ou cópia autenticada de documento comprovativo dos créditos 
reclamados pelo trabalhador, emitida pelo AI, há que ter, ainda, em conta a fase da verificação de créditos no processo de insolvência.

Esta fase inicia-se com a reclamação de créditos. Um credor tem o prazo designado na sentença para apresentar a sua reclamação de créditos, que pode ir até trinta dias (arts. 128. ${ }^{\circ},{ }^{\circ} .^{\circ} 1$ e $36 .^{\circ}$, n. ${ }^{\circ} 1, \mathrm{j}$ ), ambos do CIRE) após a notificação ou citação (com éditos de cinco dias, no caso de publicação no portal Citius) da sentença de declaração da insolvência ( $\operatorname{art}^{\circ}{ }^{\circ} 37^{\circ}$ do CIRE). Ou seja, há que, desde logo, contar com, por regra, mais de um mês.

Depois do termo do prazo das reclamações, o AI tem quinze dias para elaborar a relação de créditos reconhecidos e não reconhecidos ( $\operatorname{art}^{\circ} 129 .^{\circ}$, n. $^{\circ} 1$ do CIRE).

Só após a elaboração dessa relação está o AI em posse dos dados necessários para poder emitir a referida declaração, porque só aí pode atestar que o crédito foi reclamado e em que termos o foi. Ou seja, pelo menos, temos mais quinze dias, a que acresce o tempo que o AI demorar a emitir a respetiva documentação.

Contudo, pode o Administrador não reconhecer como devido o crédito do trabalhador (art. ${ }^{\circ}$ 129. ${ }^{\circ}$, n. 3 do CIRE) e, por isso, não emitir a referida declaração. Segue-se, então, a impugnação da lista, no prazo de dez dias (art. $130 .^{\circ}$, n. $^{\circ} 1$ do CIRE), com possível resposta, também no prazo de dez dias, do AI e qualquer interessado que assuma posição contrária, incluindo o devedor ( $\operatorname{art}^{\circ} 131 .^{\circ}$, n. $^{\circ} 1$ e n. ${ }^{\circ} 3$ ), e se a houver (art. ${ }^{\circ} 131 .^{\circ}$, n. $^{\circ} 3$ do CIRE), temos, ainda, a emissão de parecer da comissão de credores, dentro dos dez dias posteriores ao termo do prazo das respostas às impugnações ( art. $^{\circ} 135 .^{\circ}$ do CIRE), a possibilidade de existir tentativa de conciliação ( art. $^{\circ} 136 .^{\circ}$ do CIRE) e a audiência de julgamento (arts. $138 .^{\circ}$ e $139 .^{\circ}$ do CIRE). Só perante uma sentença favorável ao trabalhador emitirá o AI a tal declaração comprovativa dos créditos reclamados. Se a sentença não for favorável, o trabalhador pode ainda recorrer para a 2. ${ }^{\text {a }}$ instância ( art. $^{\circ} 14 .^{\circ}$ ) e, ainda mais, terá de aguardar.

A esta delonga poder-se-ia contrapor que a única declaração que o AI tem de emitir é a comprovar que reclamou créditos e não que houve o seu reconhecimento. Recordamos, aliás, que um argumento deste tipo foi usado no Ac. n. ${ }^{\circ}$ 3, acima referenciado, para defender a intempestividade do exercício do direito do trabalhador.

Contudo, caso o Administrador se recusasse a emitir a referida declaração, restar-lhe-ia recorrer, nos termos do art. ${ }^{\circ} 5^{\circ}$, n. $^{\circ}$ 2, alínea c) do NRFGS, à Autoridade para as Condições do Trabalho. No entanto, diz, pelo menos, a nossa experiência que a atuação desta entidade não é tão célere quanto desejável. Além do que, para ser suscitada a sua intervenção, tem de haver 
recusa por parte do AI, o que implica que se tem de passar por parte da tramitação acima indicada. Ou seja, mais uns dias se passaram, entretanto.

Admitimos, ainda, que se possa solicitar a emissão, por parte do AI, da tal declaração, após a elaboração da lista provisória de credores do art. ${ }^{\circ} 154 .^{\circ}$ do CIRE. O problema é que, se o AI juntar essa lista pelo menos oito dias antes da assembleia de apreciação do relatório (art. ${ }^{\circ} 155$. $^{\circ}$, n. 3 do CIRE), os credores podem não conseguir integrar esta lista, por ainda não se ter findado o prazo da reclamação de créditos.

De qualquer dos modos, reiteramos, com esta fase perde-se sempre mais de 1 mês, a que acresce o tempo que o AI demorar a emitir a respetiva documentação.

E outras sub-hipóteses se poderiam suscitar - e que, para que não se torne demasiado fastidioso, nos limitamos a elencar - como os créditos do trabalhador serem reclamados após terminar o prazo para a reclamação de créditos, através da verificação ulterior de créditos ( $\operatorname{art}^{\circ} 146 .^{\circ}$ do CIRE), como aconteceu no Ac. n. ${ }^{\circ}$ 3, em que o trabalhador esteve um ano e três meses à espera da sentença para reconhecimento do seu créditos, ou a sentença de declaração de insolvência ser proferida de acordo com o art. ${ }^{\circ} 39 .^{\circ}$ do CIRE, por insuficiência da massa insolvente, sem ser designado prazo para a reclamação de créditos, o que obrigaria ao pedido de complemento de sentença (art. ${ }^{\circ} 39 .^{\circ}$, n. $^{\circ} 1$, n. $^{\circ} 2$, al. a), n. ${ }^{\circ} 3$ e n. ${ }^{\circ} 4$ do CIRE).

E o mesmo problema pode acontecer no PER.

Desde logo, só o devedor tem legitimidade processual para dar início a esse procedimento (art. ${ }^{\circ}$ 17. ${ }^{\circ}-\mathrm{C}$, n. $^{\circ}$ s 1,2 e n. ${ }^{\circ} 3$, a) do CIRE).

Portanto, o trabalhador-credor não tem qualquer controlo relativamente ao início deste processo.

Depois do devedor dar início ao processo, o juiz deve nomear, se cumprido o art. ${ }^{\circ} 17 .^{\circ}-\mathrm{C}$, n. $^{\circ} 4$ do CIRE (anterior n. ${ }^{\circ}$ 3, al. a)), de imediato, por despacho, AJP.

Este despacho será, depois, publicado no portal Citius, e, a partir daí correrá o prazo de vinte dias para os credores reclamarem os seus créditos (art. ${ }^{\circ} 17^{\circ}-\mathrm{D}, \mathrm{n}^{\circ}{ }^{2}$ ) do CIRE).

Se cumprido o art. $^{\circ} 17 .^{\circ}-\mathrm{D}$, n. $^{\circ} 2,2 .^{\mathrm{a}}$ parte do CIRE, no prazo de cinco dias após o termo do prazo da reclamação de créditos, o AJP elabora uma lista provisória de créditos.

Contudo, essa lista pode ser impugnada no prazo de cinco dias úteis, dispondo o juiz, em seguida, se cumprido o art. ${ }^{\circ} 17 .^{\circ}-\mathrm{D}$, n. $^{\circ} 3$ do CIRE, de idêntico prazo para decidir sobre as impugnações formuladas. 
Após a lista provisória de créditos, ou a decisão sobre as impugnações, está o AJP habilitado a emitir a documentação necessária para o trabalhador requerer o pagamento dos créditos laborais ao FGS.

Ora, só contando desde a publicação do despacho de nomeação do AJP, medeia, pelo menos, um mês.

A que acresce o tempo que o AJP necessita para emitir a documentação, sem olvidar que, na prática, não é raro o incumprimento dos prazos legais de nomeação do AJP, da junção da lista provisória de créditos, e da decisão sobre as impugnações.

Em suma, como pensamos que ficou amplamente exemplificado, é uma possibilidade real que o trabalhador, por fatores a que é totalmente alheio, não possa entregar o requerimento para pagamento dos créditos laborais pelo FGS, dentro do prazo de um ano a partir do dia seguinte àquele em que cessou o seu contrato de trabalho.

Aliás, pelas perguntas feitas ao TJ, pelo TAF de Viseu, em sede de reenvio prejudicial, a que aludimos acima, depreendemos que terá sido esta realidade que terá motivado o pedido prejudicial.

Mas, e o entendimento vertido pela primeira das duas teses que referimos não resolve o problema?

Esse entendimento, por muito que possa resolver vários casos "apanhados" na transição de um regime para outro - o que, pelo menos, se saúda - não resolve outros tantos:

a) Quando os contratos de trabalho cessaram antes da data da entrada em vigor do NRFGS e o requerimento tenha sido apresentado após 4 de maio de 2016; e

b) Relativamente aos contratos de trabalho que cessaram após a data da entrada em vigor do NRFGS, em que os trabalhadores, por motivos a si alheios, conforme ilustrámos, se viram impedidos de cumprir o prazo do $\operatorname{art}^{\circ}{ }^{2} .^{\circ}$, n. $^{\circ} 8$ do NRFGS.

A questão essencial mantém-se, portanto, por resolver. Essa tese responde, somente, tendo por base normas sobre alteração de prazos, quando a discordância aqui expressa é mais profunda, por ser relativa à validade e à interpretação da própria norma que altera o prazo.

Consequentemente, na sequência do afirmado pelo TJ, e ao abrigo do art. ${ }^{\circ} 8 .^{\circ}$, n. $^{\circ} 4$ da CRP (Canotilho e Moreira, 2014, 271), dado que o art. ${ }^{\circ}$ 2. $^{\circ}$, n. 8 do NRFGS não está em conformidade com as exigências do Direito Comunitário, no caso, pelo menos, indubitavelmente, quanto ao princípio da efetividade, e se se entender que nenhuma interpretação conforme com o Direito Comunitário é possível, deve, então, ser recusada a sua aplicação ou podem os tribunais pedir ao TJ, ao abrigo do art. ${ }^{\circ} 267 .^{\circ}$ do Tratado sobre o 
Funcionamento da União Europeia que se pronuncie sobre o correto entendimento ou a validade desta disposição, em sede de reenvio prejudicial.

Por isso, não podemos concordar com os Acs. do segundo grupo - a interpretação dada não é conforme a Diretiva 2008/94/CE, nem com a jurisprudência comunitária (aliás, a citada pelo Ac. n. 2 não tem a ver com esta questão) e não é respeitada a finalidade social daquela.

Por outro lado, julgamos que a norma está, igualmente, ferida de inconstitucionalidade, por violação material do art. ${ }^{\circ} 59 .^{\circ}$, n. $^{\circ} 2$ e n..$^{\circ} 3$ da CRP.

Voltando à contextualização feita, nos termos do $\operatorname{art}^{\circ}{ }^{59} .^{\circ}$, n. $^{\circ} 2$ da CRP, o Estado tem a expressa incumbência constitucional de assegurar a retribuição a que os trabalhadores têm direito, e nos termos do . $^{\circ}$, é constitucionalmente consagrado que os salários gozam de garantias especiais. Prevendo a lei ordinária um prazo que impossibilita, na prática, a um trabalhador de beneficiar da garantia especial de ver os seus créditos salariais pagos pelo FGS, tal significa que o Estado se frustou à referida incumbência constitucional de assegurar o pagamento da retribuição, e, igualmente, que o salário não beneficiou de garantia especial.

\section{Conclusão}

A redação do art. $^{\circ} 2 .^{\circ}$, n. $^{\circ} 8$ do NRFGS tem dois problemas: o prazo para requerer o pagamento ao FGS deixou de estar indexado ao prazo de prescrição dos créditos laborais e, por isso, deixou de aproveitar as causas de interrupção da prescrição, e o legislador manteve, como data relevante para o início da contagem, a data da cessação do contrato de trabalho.

Problemas que o legislador deve resolver, por forma a respeitar a Diretiva 2008/94/CE e a nossa Constituição. Como?

Alvitramos três hipóteses:

1) Voltar à redação anterior;

2) Manter a redação atual, mas prever casos de interrupção e suspensão para o prazo, o que, mesmo sendo este de caducidade, é permitido pela parte final do art. ${ }^{\circ} 328 .^{\circ}$ do $\mathrm{CC}$;

3) Estipular um prazo, por exemplo, de trinta dias desde o reconhecimento do crédito no processo de insolvência, PER ou procedimento extrajudicial de recuperação.

Sugerimos, por último, na senda do aconteceu por causa do FGS ter indeferido o pagamento de créditos laborais reclamados no âmbito do PER (Abrantes, 2015, 411), e atentos os interesses que estão em causa, a reapreciação oficiosa, ou, pelo menos, a concessão de um prazo para requerer a reanálise da decisão, dos requerimentos que deram entrada após a entrada em vigor 
do NRFGS e que foram indeferidos, somente, pelo facto do pagamento não ter sido requerido a partir do dia seguinte àquele em que cessou o contrato de trabalho.

P.S.: Após termos submetido este artigo, a 31 de maio, foi publicado o Ac. do Tribunal

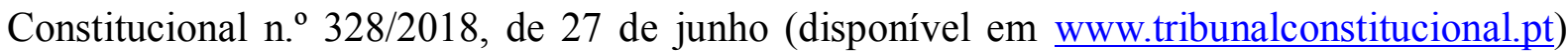
que, em sede de fiscalização concreta, decidiu "julgar inconstitucional a norma contida no artigo $2 .^{\circ}$, n. ${ }^{\circ} 8$, do Decreto-Lei n. ${ }^{\circ}$ 59/2015, de 21 de abril, na interpretação segundo a qual o prazo de um ano para requerer o pagamento dos créditos laborais, certificados com a declaração de insolvência, cominado naquele preceito legal é de caducidade e insuscetível de qualquer interrupção ou suspensão".

Da argumentação expendida, permitimo-nos destacar o seguinte trecho: "Não é inócua a apontada ligação entre o mecanismo do FGS e a norma do n. ${ }^{\circ} 3$ do artigo 59. ${ }^{\circ}$ da CRP. Tratando-se de uma das garantias ali previstas, ao escolher (apesar de, nessa escolha, se encontrar vinculado pelo Direito da União) instituir o FGS como uma das garantias especiais da retribuição, o legislador está vinculado à construção de um regime que lhe assegure um mínimo de efetividade, sem a qual resultaria esvaziada de sentido a norma constitucional, com respeito pela igualdade (artigos $13 .^{\circ} \mathrm{e}$ 59. ${ }^{\circ}$, n. ${ }^{\circ} 1$, da CRP). Por outro lado, tratando-se de atribuir, no apontado contexto, um direito a uma prestação pecuniária, e de limitar no tempo a efectividade desse direito pelo não exercício, tal atribuição deve operar, na compaginação destas duas vertentes, segundo regras claras, certas e objetivas exigência decorrente do princípio do Estado de direito democrático (artigo $2 .^{\circ}$ da Constituição).

Tendo presentes as linhas essenciais do NRFGS (...) verificam-se aporias que o afastam do padrão de efetividade e certeza acabado de traçar."

\section{Referências}

- AAVV (2004). Código do Trabalho - Anotado (3. a edição). Coimbra: Almedina. 
- Abrantes, José João (2015). O Fundo de Garantia Salarial nos processos de insolvência e de revitalização. In Catarina Serra (Ed.), III Congresso de Direito da Insolvência (pp. 409 - 412). Coimbra: Almedina.

- Amado, João Leal Amado (1994). A Proteção do Salário. Boletim da Faculdade de Direito da Universidade de Coimbra - Suplemento vol. XXXIX, pp. 1 - 260.

- Canotilho, J.J. Gomes \& Moreira, Vital (2014). Constituição da República Portuguesa: anotada-artigos $1 .^{\circ}$ a $107 .^{\circ}$ (4. ${ }^{\mathrm{a}}$ edição revista). Coimbra: Coimbra Editora.

- Costeira, Joana (2017). Os Efeitos da Declaração de Insolvência no Contrato de Trabalho: A Tutela dos Créditos Laborais (2. a edição). Coimbra: Almedina.

- Domingos, Maria Adelaide (2009). A tutela dos créditos laborais através do Fundo de Garantia Salarial. In António Moreira (Ed.), XI-XII Congresso Nacional de Direito do Trabalho (pp. 249 - 270). Coimbra: Almedina.

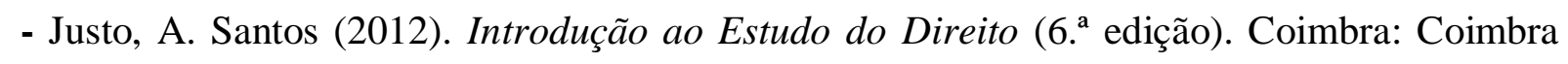
Editora.

- Monteiro, Leonor Pizarro (2016). O Trabalhador e a Insolvência da Entidade Empregadora. Coimbra: Almedina.

- Pires, Miguel Lucas (2015). Dos Privilégios Creditórios (2. edição). Coimbra: Almedina.

- Serra, Catarina (2017). PER, PROCESSOS E CRÉDITOS LABORAIS - Uma análise tridimensional (jurisprudência, novíssimo Direito da Insolvência e projectado Direito Europeu. Prontuário de Direito do Trabalho, 2017 - II, pp. 159 
